\title{
AVALIAÇÃO DO COMPORTAMENTO DE LEITÕES EM DIFERENTES SISTEMAS DE AQUECIMENTO POR MEIO DA ANÁLISE DE IMAGEM E IDENTIFICAÇÃO ELETRÔNICA
}

\section{HÉLITON PANDORFI}

Dissertação apresentada à Escola Superior de Agricultura "Luiz de Queiroz", Universidade de São Paulo, para obtenção do título de Mestre em Agronomia, Área de Concentração: Física do Ambiente Agrícola.

\author{
PIRACICABA \\ Estado de São Paulo - Brasil \\ Novembro - 2002
}




\title{
AVALIAÇÃO DO COMPORTAMENTO DE LEITÕES EM DIFERENTES SISTEMAS DE AQUECIMENTO POR MEIO DA ANÁLISE DE IMAGEM E IDENTIFICAÇÃO ELETRÔNICA
}

\author{
HÉLITON PANDORFI \\ Engenheiro Agrônomo
}

Orientador : Prof. Dr. IRAN JOSÉ OLIVEIRA DA SILVA

Dissertação apresentada à Escola Superior de Agricultura "Luiz de Queiroz", Universidade de São Paulo, para obtenção do título de Mestre em Agronomia, Área de Concentração: Física do Ambiente Agrícola.

PIRACICABA

Estado de São Paulo - Brasil

Novembro - 2002 
Dados Internacionais de Catalogação na Publicação (CIP)

DIVISÃO DE BIBLIOTECA E DOCUMENTAÇÃO - ESALQ/USP

Pandorfi, Héliton

Avaliação do comportamento de leitões em diferentes sistemas de aquecimento por meio da análise de imagem e identificação eletrônica / Héliton Pandorfi. - Piracicaba, 2002.

89 p. : il.

Dissertação (mestrado) - - Escola Superior de Agricultura Luiz de Queiroz, 2002.

Bibliografia.

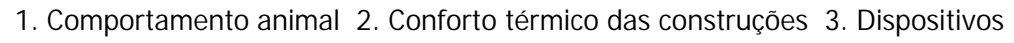
eletrônicos - Identificação 4. Geoestátistica 5. Leitões 6. Processamento de imagens 7. Temperatura ambiente I. Título

CDD 636.4 


\section{AGRADECIMENTOS}

A Deus, que me iluminou e me deu forças nos momentos em que mais precisei para vencer os obstáculos surgidos durante esse percurso.

À Escola Superior de Agricultura "Luiz de Queiroz", pelas tantas oportunidades oferecidas.

Ao Professor Dr. Iran José Oliveira da Silva, pela orientação, amizade, confiança, incentivo e entusiasmo na execução deste trabalho, responsável pelo meu crescimento pessoal e científico.

À Professora Dra. Daniella Jorge de Moura, pelos ensinamentos, sugestões, amizade e incansável apoio àrealização deste trabalho.

Ao Sr. Paulo Cesar Micheloni, gerente da granja Querência, pela atenção, confiança, sugestões e colaboração para o desenvolvimento deste trabalho, viabilizando a instalação e execução do experimento a campo.

Aos professores do Programa de Pós-Graduação em Física do Ambiente Agrícola, pelos ensinamentos e oportunidade de realização do curso.

Aos professores Paulo Cesar Sentelhas, Sergio Oliveira Moraes, Valdomiro Shigueru Miyada, pelos ensinamentos, sugestões para a melhoria e engrandecimento deste trabalho.

À Professora Sônia Maria Piedade, pelo auxílio na definição e execução das análises estatísticas.

Aos professores Luiz Antonio Rossi e Antonio Ludovico Beraldo (Feagri/UNICAMP), pela atenção e pelo fornecimento das placas de compósitos biomassa vegetal-cimento, para que pudéssemos enriquecer a avaliação dos diferentes sistemas de aquecimento.

Ao professor Dr. Carlos Alberto Vettorazzi, pelo apoio e sugestões na 
aplicação da geoestatística neste trabalho.

Ao colega Ivan Wladimir Caro, pelo incansável apoio na instalação do experimento a campo.

A minha irmã Viviane Pandorfi, pelo apoio e companheirismo na coleta de dados a campo.

Ao amigo Fábio Ricardo Marin, pelas orientações, ensinamentos, discussões e estimada amizade.

Aos colegas do Núcleo de Pesquisa em Ambiência, Mauríco Perissinotto, Soraia Vanessa Matarazzo, Edilaine Regina Pereira, José Luis Martins, Kelly Botigeli Sevegnani, pela amizade e apoio direto e indireto na realização deste trabalho. Aos colegas do Curso de Pós-Graduação em Física do Ambiente Agrícola, pelo convívio e amizade durante a realização do curso.

À Fundação de Amparo à Pesquisa - FAPESP, pelo financiamento para a realização desta pesquisa.

À Coordenação de Aperfeiçoamento de Pessoal de Nível Superior (CAPES) pela concessão da bolsa de estudos. 


\section{SUMÁRIO}

Página

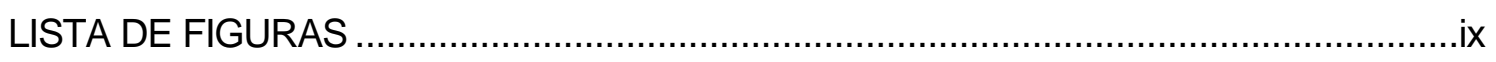

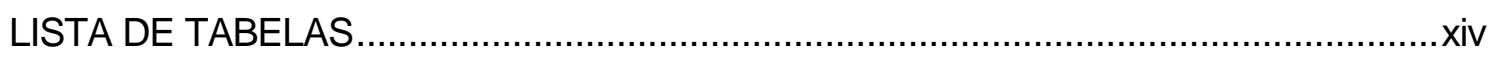

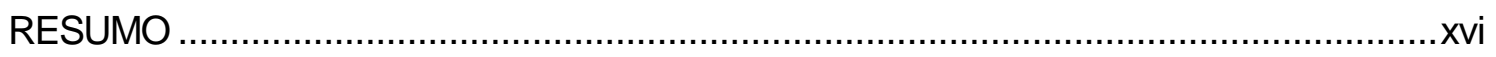

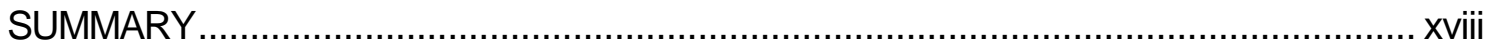

1 INTRODUÇÃO

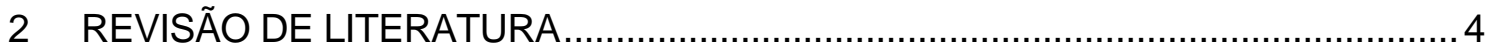

2.1 Ambiência na produção de suínos....................................................................

2.1.1 Exigências térmicas na maternidade ......................................................... 4

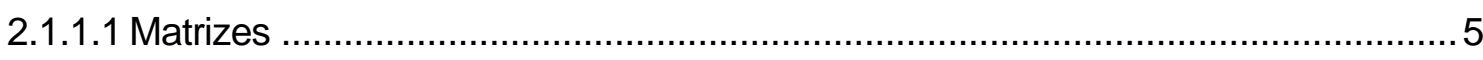

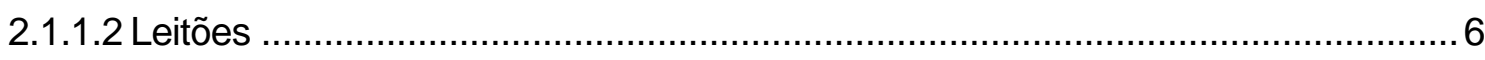

2.1.2 Instalações para maternidade de suínos .......................................................

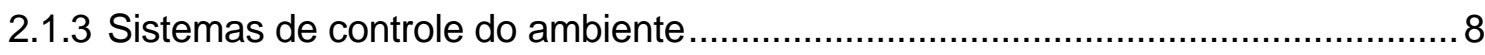

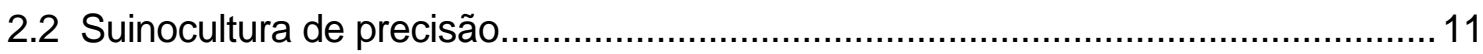

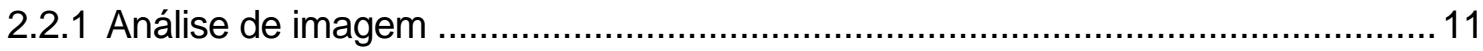

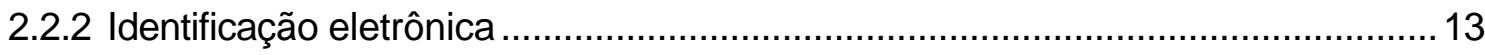

2.2.2.1 Sistemas de identificação eletrônica............................................................. 14

2.2.2.2 Identificação com transponders injetáveis ................................................... 17

2.3 Tolerância biológica do transponder no animal ..................................................... 18

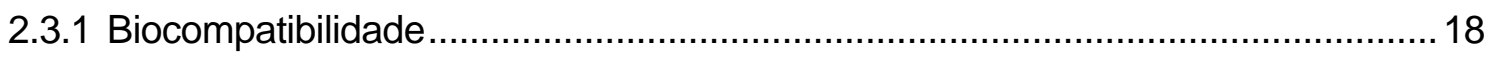

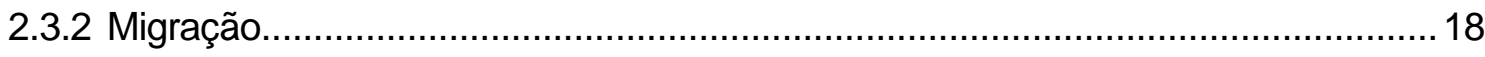

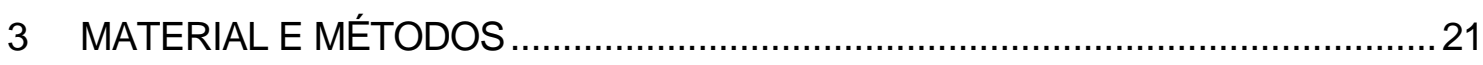

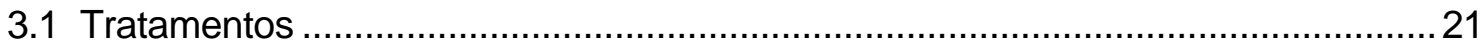

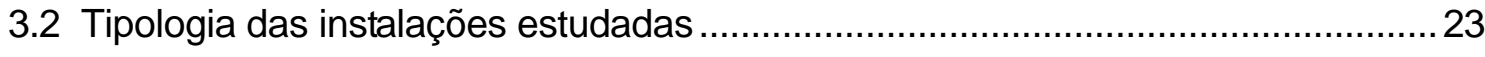

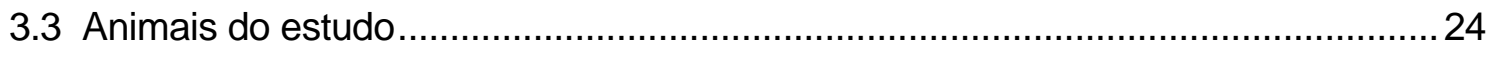

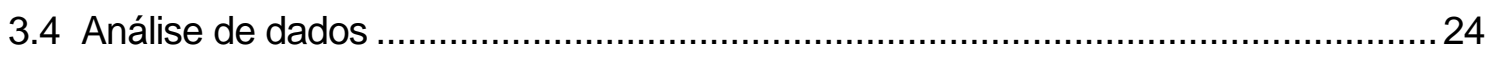




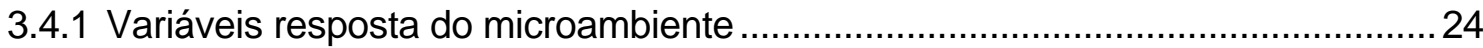

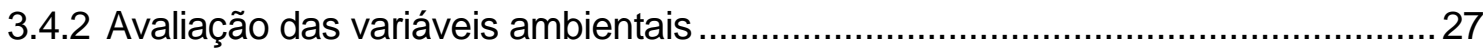

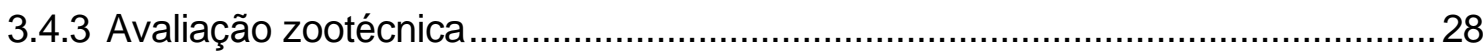

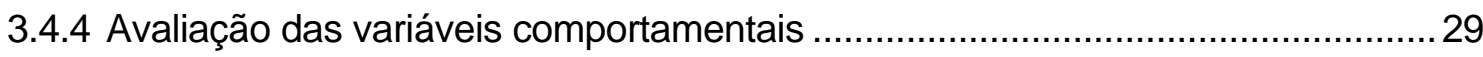

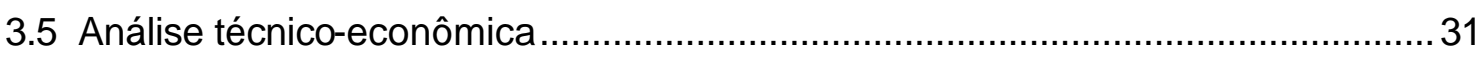

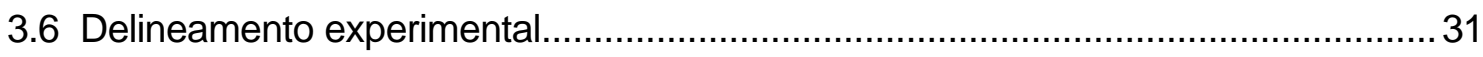

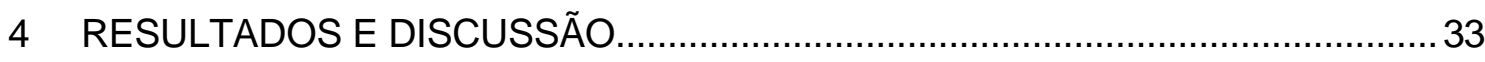

4.1 Análise dos dados de verão ……………………........................................... 33

4.1.1 Análise das variáveis ambientais e a eficiência térmica dos sistemas

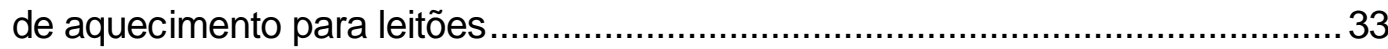

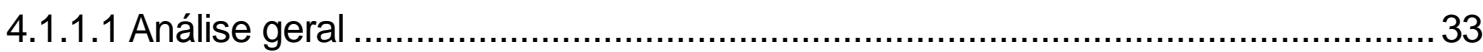

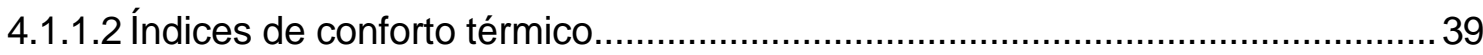

4.1.2 Avaliação comportamental dos leitões no verão................................................ 43

4.1.2.1 Freqüência de acesso dos leitões ao abrigo escamoteador .............................. 43

4.1.2.2 Tempo de permanência dos leitões no interior dos abrigos

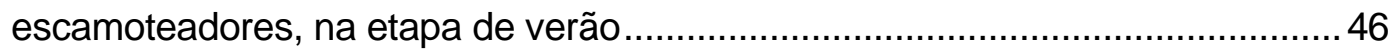

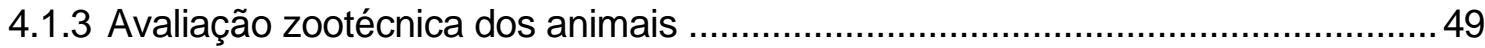

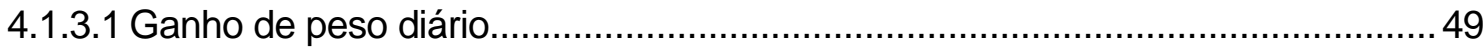

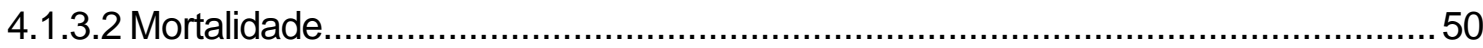

4.1.4 Avaliação técnico-econômica dos sistemas de aquecimento ..............................50

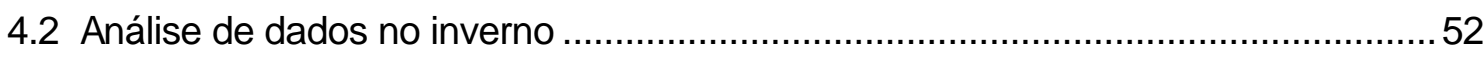

4.2.1 Análise das variáveis ambientais e a eficiência térmica dos sistemas

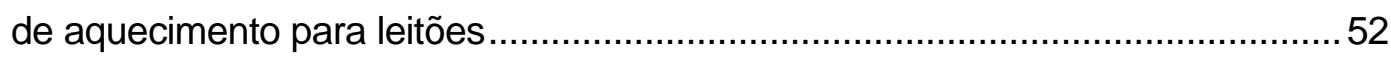

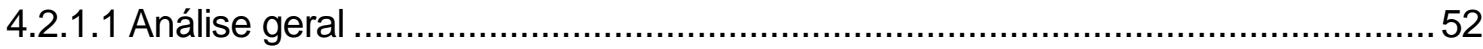

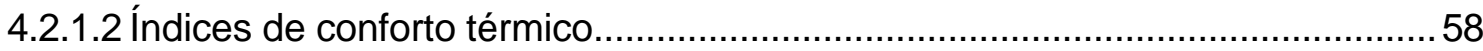

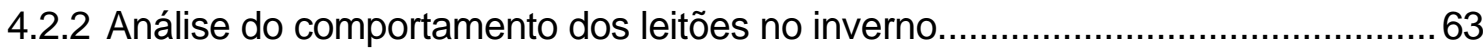

4.2.2.1 Freqüência de acesso dos leitões ao abrigo escamoteador ................................. 63

4.2.2.2 Tempo de permanência dos leitões no interior dos abrigos escamoteadores

4.2.2.3 Análise do comportamento dos leitões, em função do uso da geoestatística na avaliação das isotermas do piso nos diferentes sistemas de aquecimento 


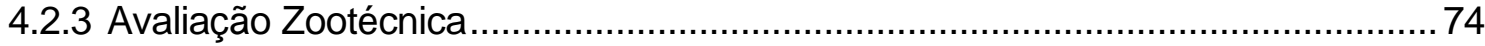

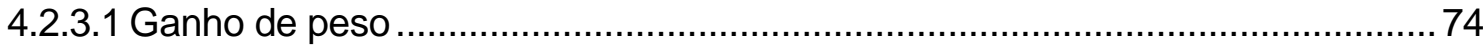

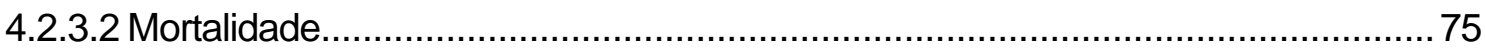

4.2.4 Avaliação técnico-econômica dos sistemas de aquecimento............................ 75

4.3 Avaliação da eficiência das ferramentas de identificação eletrônica por análise de imagem e transponders (IDRF) .............................................. 78

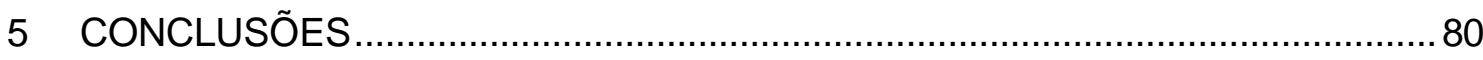

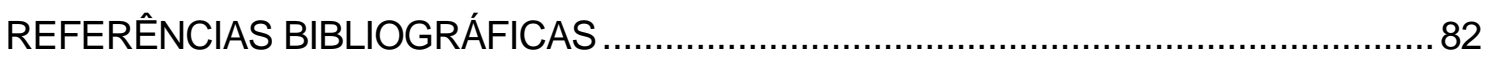




\section{LISTA DE FIGURAS}

Página

1 Piso térmico de compósitos biomassa vegetal-cimento aquecido por meio de resistência elétrica. .............................................................................. 22

2 Abrigo escamoteador equipado com lâmpada incandescente (200W)............... 22

3 Escamoteador equipado com resistência elétrica (200W)............................... 22

4 Abrigo escamoteador equipado com lâmpada de infravermelho (250W).

5 Esquema geral da distribuição dos tratamentos na maternidade........................ 24

6 Sensores acoplados na tampa do abrigo escamoteador. .................................. 25

7 Disposição dos sensores no interior da sala da maternidade............................. 25

8 Abrigo meteorológico instalado no ambiente externo, próximo àsala da maternidade.

9 Representação esquemática dos pontos de medida de temperatura de piso nos abrigos escamoteadores.

10 Aplicação do transponder na região da inserção da base da orelha. ................... 30

11 Detalhe do microchip utilizado na identificação eletrônica dos animais............... 30

12 Microcâmera, leds de infravermelho e antena de captação do sinal dos microchips, instalados no interior do abrigo escamoteador.

13 Representação da correlação entre temperatura na sala da maternidade e no abrigo meteorológico (ambiente externo), na etapa de verão, envolvendo todos os dados coletados. 
14 Variação da temperatura média diária na etapa de verão nos diferentes tratamentos na sala da maternidade e no abrigo meteorológico (ambiente externo).

15 Variação da temperatura mínima diária na etapa de verão nos diferentes tratamentos, sala da maternidade, abrigo meteorológico (ambiente externo) e conforto.

16 Variação da temperatura para os dias de menor entalpia na etapa de verão nos diferentes tratamentos avaliados

17 Variação da umidade relativa média diária na etapa de verão nos diferentes tratamentos na sala da maternidade e no abrigo meteorológico (ambiente externo).

18 Variação do índice de temperatura de globo e umidade para os dias de menor entalpia na etapa de verão nos diferentes tratamentos avaliados.

19 Variação da carga térmica radiante para os dias de menor entalpia na etapa de verão nos diferentes tratamentos avaliados.

20 Variação da entalpia média diária na etapa de verão nos diferentes tratamentos na sala da maternidade e no abrigo meteorológico (ambiente externo).

21 Variação da entalpia mínima diária na etapa de verão nos diferentes tratamentos na sala da maternidade e no abrigo meteorológico (ambiente externo).

22 Avaliação da freqüência de uso do abrigo escamoteador equipado com piso térmico (a); lâmpada incandescente (b); resistência elétrica (c); lâmpada de infravermelho (d) e a variação da temperatura no interior da sala da maternidade para o dia avaliado (29/03/02) 
23 Porcentagem média do tempo de permanência dos leitões no abrigo escamoteador equipado com piso térmico (a), lâmpada incandescente (b), resistência elétrica (c) e lâmpada de infravermelho (d) com o sistema de aquecimento acionado, durante 11 horas, para os dias críticos na etapa de verão.

24 Ganho de peso (kg/dia), dos leitões submetidos aos diferentes sistemas de aquecimento na etapa de verão.

25 Consumo de energia elétrica $(\mathrm{kWh})$ dos diferentes sistemas de aquecimento, durante a etapa de verão.

26 Representação da correlação entre temperatura na sala da maternidade e no ambiente externo, na etapa de inverno, envolvendo todos os dados coletados

27 Variação da temperatura média diária na etapa de inverno nos diferentes tratamentos na sala da maternidade e no abrigo meteorológico (ambiente externo).

28 Variação da temperatura mínima diária na etapa de inverno nos diferentes tratamentos, sala da maternidade e no abrigo meteorológico (ambiente externo).

29 Variação da temperatura para os dias de menor entalpia na etapa de inverno nos diferentes tratamentos avaliados.

30 Variação da umidade relativa média diária na etapa de inverno nos diferentes tratamentos na sala da maternidade e no abrigo meteorológico (ambiente externo).

31 Variação do índice de temperatura de globo e umidade para os dias de menor entalpia na etapa de inverno nos diferentes tratamentos avaliados

32 Variação da carga térmica radiante (CTR), para os dias de menor entalpia, na etapa de inverno, nos diferentes tratamentos avaliados. 
33 Variação da entalpia média diária na etapa de inverno nos diferentes tratamentos na sala da maternidade e no abrigo meteorológico (ambiente externo).

34 Variação da entalpia mínima diária na etapa de inverno nos diferentes tratamentos na sala da maternidade e no abrigo meteorológico (ambiente externo).

35 Avaliação da freqüência de acesso do abrigo escamoteador equipado com piso térmico (a), lâmpada incandescente (b); resistência elétrica (c); lâmpada de infravermelho (d) e a variação da temperatura na sala da maternidade na etapa de inverno, para o dia avaliado (03/08/02).

36 Porcentagem média do tempo de permanência dos leitões no abrigo escamoteador equipado com piso térmico (a), lâmpada incandescente (b), resistência elétrica (c) e lâmpada de infravermelho (d), durante as 24 horas de acionamento do sistema, na etapa de inverno para os dias críticos avaliados.

37 Imagem capturada (a) e representação das isotermas (b), representando o perfil de distribuição dos animais, para o abrigo equipado com piso térmico, para æ̀̀ 8:00 horas na etapa de inverno (03/08/02).

38 Imagem capturada (a) e representação das isotermas (b), representando o perfil de distribuição dos animais, para o abrigo equipado com piso térmico, para æ̀ 16:00 horas na etapa de inverno (03/08/02).

39 Imagem capturada (a) e representação das isotermas (b), representando o perfil de distribuição dos animais, para o abrigo equipado com lâmpada incandescente, para æ̀̀ 8:00 horas na etapa de inverno (03/08/02). 
40 Imagem capturada (a) e representação das isotermas (b), representando o perfil de distribuição dos animais, para o abrigo equipado com lâmpada incandescente, para æ̀̀ 16:00 horas na etapa de inverno (03/08/02).

41 Imagem capturada (a) e representação das isotermas (b), representando o perfil de distribuição dos animais, para o abrigo equipado com resistência elétrica, para æ̀s 8:00 horas na etapa de inverno (03/08/02).

42 Imagem capturada (a) e representação das isotermas (b), representando o perfil de distribuição dos animais, para o abrigo equipado com resistência elétrica, para æ̀̀ 16:00 horas na etapa de inverno (03/08/02).

43 Imagem capturada (a) e representação das isotermas (b), representando o perfil de distribuição dos animais, para o abrigo equipado com lâmpada de infravermelho, para æ̀s 8:00 horas na etapa de inverno (03/08/02).

44 Imagem capturada (a) e representação das isotermas (b), representando o perfil de distribuição dos animais, para o abrigo equipado com lâmpada de infravermelho, para æ̀s 16:00 horas na etapa de inverno (03/08/02).

45 Ganho de peso (kg/dia), dos leitões submetidos aos diferentes sistemas de aquecimento na etapa de inverno.

46 Consumo de energia elétrica ( $\mathrm{kWh}$ ) dos diferentes sistemas de aquecimento para as etapas de verão e inverno.

47 Variação do número de animais captados pela câmera de vídeo e pelas antenas de recepção do sinal emitido pelos microchips

48 Representação da correlação entre registro de dados pelas antenas e pelas microcâmeras. 


\section{LISTA DE TABELAS}

Página

1 Temperatura exigida pelos leitões para as diferentes idades........................... 5

2 Temperatura média, máxima e mínima $\left({ }^{\circ} \mathrm{C}\right)$, registradas nos escamoteadores na maternidade................................................................. 9

3 Efeito do escamoteador sobre a mortalidade de leitões................................. 9

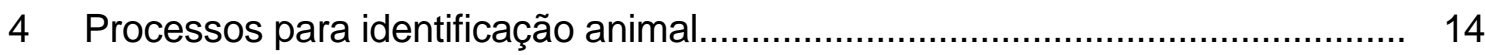

$5 \quad$ Análise da variância utilizada na pesquisa. ............................................... 31

6 Valores médios diários das variáveis ambientais observadas no abrigo escamoteador durante a permanência dos leitões na maternidade, na etapa de verão...................................................................................... 34

7 Valores médios dos índices de conforto, ITGU, CTR e H, observados na primeira etapa (verão), durante a permanência dos leitões na maternidade.

8 Equações de regressão ajustadas para porcentagem de animais no abrigo, em função da temperatura da sala da maternidade, correspondente à ${ }^{\mathrm{a}}$ semana, para os tratamentos adotados.

9 Porcentagem de permanência do tempo total (24 horas) no decorrer de cada dia crítico analisado de, pelo menos 1 leitão, no interior do abrigo escamoteador para os diferentes sistemas de aquecimento na etapa de verão

10 Valor total $(\mathrm{R} \$)$, pago pelo consumo de energia elétrica $(\mathrm{kWh})$, dos diferentes sistemas de aquecimento avaliados. 
11 Valores médios das variáveis ambientais observados durante a permanência dos leitões na maternidade.

12 Valores médios dos índices de conforto, ITGU, CTR e H, observados na segunda etapa (inverno), durante a permanência dos leitões na maternidade.

13 Equações de regressão ajustadas para porcentagem de animais no abrigo, em função da temperatura da sala da maternidade, correspondente à $3^{\mathrm{a}}$ semana da etapa de inverno, para os tratamentos adotados.

14 Porcentagem de permanência do tempo total (24 horas) no decorrer de cada dia analisado de, pelo menos 1 leitão, no interior do abrigo escamoteador para os diferentes sistemas de aquecimento na etapa de inverno.

15 Valores horários de temperatura no interior da sala da maternidade, para o dia crítico $(03 / 08 / 02)$.

16 Valor total $(R \$)$, pago pelo consumo de energia elétrica $(k W h)$, dos diferentes sistemas de aquecimento avaliados e o seu rendimento $(R \$)$, para fase de verão e inverno. 


\title{
AVALIAÇÃO DO COMPORTAMENTO DE LEITÕES EM DIFERENTES SISTEMAS DE AQUECIMENTO POR MEIO DA ANÁLISE DE IMAGEM E IDENTIFICAÇÃO ELETRÔNICA
}

\author{
Autor: HÉLITON PANDORFI \\ Orientador: Prof. Dr. IRAN JOSÉ OLIVEIRA DA SILVA
}

\section{RESUMO}

O objetivo geral desta pesquisa foi o de avaliar o comportamento de leitões em diferentes sistemas de aquecimento por meio da análise de imagem e identificação eletrônica. O experimento foi realizado no período de 12 de janeiro de 2002 a 05 de agosto de 2002, em uma propriedade de produção industrial de suínos, localizada no município de Elias Fausto, estado de São Paulo. A pesquisa foi desenvolvida na sala da maternidade, com 80 animais entre o nascimento e o desmame, para cada etapa estudada. $O$ estudo foi dividido basicamente em duas etapas: verão (fevereiro a março de 2002) e inverno (junho a agosto de 2002). Os tratamentos adotados para avaliação da eficiência dos diferentes sistemas de aquecimento foram: piso térmico, lâmpada incandescente, resistência elétrica e lâmpada de infravermelho. A avaliação física dos ambientes, foram realizadas por meio das variáveis ambientais, temperatura de bulbo seco (Ts), temperatura de bulbo úmido (Tu) e temperatura de globo negro (Tg), registrados por meio de cabos termopares tipo $\mathrm{T}$, em intervalo horário e armazenados 
em uma plataforma automática de dados. Os índices de conforto térmico determinados foram: índice de temperatura de globo e umidade (ITGU), carga térmica radiante $(C T R)$ e entalpia $(H)$, calculados usando as variáveis ambientais registradas. Os dados ambientais foram registrados no ambiente externo, sala da maternidade e no interior de cada abrigo escamoteador avaliado, durante as duas etapas, ao longo de 19 dias. Para avaliação zootécnica foram registrados o ganho de peso diário (GPD) e mortalidade. A análise técnico-econômica foi feita considerando o consumo de energia elétrica e o GPD dos animais. O delineamento experimental foi em blocos casualizados com 4 tratamentos e 18 blocos, as médias foram comparadas pelo teste de Tukey $(\mathrm{P}<0,01)$. A avaliação comportamental foi realizada utilizando a análise de imagem, identificação eletrônica e aplicação de geoestatística. Os resultados indicaram que para etapa verão, o uso de aquecimento é desnecessário. Porém, para etapa de inverno, o uso de piso térmico foi recomendado, em função do maior tempo de permanência dos animais e freqüência de acesso dos mesmos ao abrigo escamoteador. Conclui-se, também, que das ferramentas tecnológicas utilizadas para análise do comportamento, a análise de imagem foi mais eficiente que a identificação eletrônica. 


\title{
EVALUATION OF THE BEHAVIOR OF PIGLETS IN DIFFERENT HEATING SYSTEMS USING ANALYSIS OF IMAGE AND ELECTRONIC IDENTIFICATION
}

\author{
Author: HÉLITON PANDORFI \\ Adviser: Prof. Dr. IRAN JOSÉ OLIVEIRA DA SILVA
}

\section{SUMMARY}

The objective of this research was to evaluated the behavior of piglets in different heating systems using the image analysis and electronic identification devices. The experiment was conducted from January $12^{\text {th }}$ of 2002 to August $05^{\text {th }}$ of 2002, in a commercial swine production farm, located in Elias Fausto city, state of São Paulo. This research was developed in the farrowing house, with 80 piglets between birth and weanning. The study was basically divided in two stages: summer (February to March of 2002) and winter (June to August of 2002). The treatments were the different heating systems: heat mat, standard heat lamp, eletric resistence and infrared lamp. Ambient dry bulb temperature (Td), wet bulb temperature (Tw) and black globe temperature (Tg), were measured with $T$ termocouples and recorded each 60 minutes in a datalogger. The thermal comfort indexes: black globe humidity index (BGHI), radiant thermal load $(R T L)$ and enthalpy $(H)$ were calculated using the recorded climatic variables. The climatic data was taken inside and outside the farrowing house and inside each studied 
creep, during two periods of 19 days long. Daily weight gain (DWG) and mortality were registered too. The statistical desing of the experiment was randomized block with 4 treatments and 18 blocks. A t-test with 1\% of probability was performed to compare the results averages. The behavior of the piglets was evaluated using the image analysis, eletronic identification and geostatistics techniques. The results indicated for summer condition that the piglet heating isn't necessary. However, for winter time the use of the heat mat creep is recommended in function of the greatest piglets permanence and their highest frequency of use. It was also conclued that among the technological tools used for the piglets behavior study, the image analysis was more efficient than the eletronic identification. 


\section{INTRODUÇÃO}

A preocupação com a produção de alimentos está cada vez mais voltada para a quantidade e a qualidade do produto final, e as suas implicações no meio ambiente. Isso está acontecendo justamente no momento em que novas tecnologias de controle surgem, novas exigências de mercado aparecem, restrições de consumo e produção crescem diariamente, em paralelo com a mudança de conceito da população, que vem exigindo um produto final de melhor qualidade. A competitividade interna e externa está acirrada de maneira a ocupar um espaço seguro no mercado.

A suinocultura é uma atividade que exige muita dedicação do criador para alcançar bons índices de produtividade e, em conseqüência, resultados econômicos satisfatórios. Fatores ambientais externos e o microclima dentro das instalações exercem efeitos diretos e indiretos sobre a produção de suínos, acarretando a redução da produtividade, com conseqüentes prejuízos econômicos àexploração.

A produção mundial de carne suína em 2001 cresceu àtaxa de $2,4 \%$ sobre 0 ano anterior, conservando a posição de proteína animal mais consumida no planeta.

Segundo dados publicados pelo USDA - Departamento de Agricultura dos Estados Unidos - foram produzidos 83.220 milhões de toneladas, destacando-se a China como maior produtor de carne suína, com uma participação de mais da metade da produção mundial, $51 \%$. Há de se destacar, também, as performances obtidas pela União Européia, $21 \%$ os Estados Unidos com 10\% do total produzido no mundo.

O Brasil, ainda em fase de crescimento, foi responsável por 2,5\% da produção mundial. As estimativas para 2002 do USDA indicam crescimento de $2 \%$ para uma produção que deverá atingir 85 milhões de toneladas.

A exportação mundial em 2001 cresceu à taxa de $2 \%$, impulsionada pelo desempenho excepcional apresentado pelo Brasil: aumento de 47\%, nas exportações. A segunda maior taxa de crescimento, 18\%, pertence aos Estados 
Unidos. A União Européia, primeiro exportador mundial, apresenta recuo de 17\% nas vendas externas, por conta dos problemas sanitários com a febre aftosa ocorridos nesse continente. O Canadá, $2^{\circ}$ maior exportador mundial, cresceu àtaxa de um dígito, $8 \%$.

É importante ressaltar que o Brasil assumiu a quarta posição entre os maiores exportadores mundiais de carne suína. As previsões das exportações mundiais para 2002 apontam para uma retomada de crescimento àtaxa de 7\%, devendo atingir 3.762 milhões de toneladas. Mais uma vez esse crescimento será puxado pelo Brasil que, segundo o USDA, deverá crescer a taxas de $21 \%$, enquanto os demais não superarão taxas de um dígito no incremento das suas exportações (Porkworld, 2001).

Assuntos como rastreabilidade da produção, selo de qualidade e zootecnia de precisão estão sendo discutidos em todas as cadeias produtivas, com o objetivo de maximizar os sistemas existentes em prol de melhorias nas condições de produção e, conseqüentemente, do produto final, visando àsegurança alimentar.

Quando se fala em segurança alimentar, envolvem-se sistemas de produção com qualidade, certificação de origem, preservação do meio ambiente e bem estar animal.

Um campo extenso a ser pesquisado e discutido é o do comportamento animal, como indicador do seu bem-estar em um sistema de produção.

Dessa forma, não se pode mais admitir que se fale de sistema de produção animal, cadeia produtiva, sem considerar esses novos conceitos. Diante disso, a utilização de novas tecnologias e ferramentas como a informática (softwares), microeletrônica, análise de imagem, sensores e atuadores, podem melhorar o trabalho experimental, favorecendo a acurácia das pesquisas, até então não alcançada pelos métodos tradicionais de observação.

$\mathrm{Na}$ suinocultura, um dos maiores problemas relacionados ao conforto térmico e bem-estar animal está na maternidade, onde se têm dois ambientes distintos a serem avaliados, com exigências bem diferenciadas. Na realidade, essa situação é um dos grandes problemas do produtor, pois, em um pequeno espaço físico, há a necessidade de proporcionar dois microambientes diferentes e, caso isso não ocorra, os desempenhos, tanto o das matrizes quanto o dos leitões não serão satisfatórios. 
Baseando-se nisso, o objetivo geral desta pesquisa consiste na avaliação de diferentes sistemas de aquecimento em abrigos escamoteadores para leitões, utilizando, como ferramentas de avaliação, a identificação eletrônica, análise de imagem e a geoestatística para o entendimento do comportamento animal.

Por outro lado, os objetivos específicos são:

- $\quad$ avaliar a eficiência dos diferentes sistemas de aquecimento em abrigos escamoteadores;

- $\quad$ avaliar a distribuição dos animais no interior dos abrigos em função dos sistemas de aquecimento e temperatura ambiente;

- $\quad$ analisar o tempo de permanência e a freqüência de uso nos abrigos em função dos diferentes sistemas estudados;

- estabelecer as isotermas nos diferentes microambientes, em relação à temperatura de piso, utilizando a geoestatística e análise de imagem;

- $\quad$ realizar a análise técnico-econômica dos diferentes sistemas de aquecimento;

- avaliar a eficiência das ferramentas tecnológicas utilizadas para análise comportamental dos animais. 


\section{REVISÃo DE LITERATURA}

\subsection{Ambiência na produção de suínos}

A ambiência na produção de suínos em clima tropical, como no Brasil, apresenta um desafio maior que em países de clima temperado, pelo fato de ter alta temperatura e umidade, que ocorrem freqüentemente, sendo de extrema importância na concepção e no dimensionamento das instalações e dos sistemas de climatização.

Sejam os fatores ambientais, os fisiológicos ou os comportamentais, todos têm sua parte na compreensão da ambiência animal. Toda essa temática sugere estudos multidisciplinares para o melhor entendimento do bem-estar animal.

Dessa forma, derrubando os limites que possam existir entre as áreas envolvidas, com certeza as respostas serão mais rápidas e completas, possibilitando que as novas tecnologias tornem a suinocultura industrial brasileira mais competitiva e empreendedora.

\subsubsection{Exigências térmicas na maternidade}

Os suínos, por suas características fisiológicas, possuem dificuldades em adaptação às flutuações térmicas ambientais. A faixa de temperatura para seu conforto varia com a idade. Para o leitão, no nascimento, a faixa de conforto está entre $32 \mathrm{e}$ $34^{\circ} \mathrm{C}$, e aos 35 dias entre 29 e $31^{\circ} \mathrm{C}$, sendo que a temperatura ideal para a matriz está entre 16 e $21^{\circ} \mathrm{C}$ (Perdomo et al., 1987).

A temperatura corporal do recém-nascido cai de 1,7 a $6,7^{\circ} \mathrm{C}$, logo após 0 nascimento. O tempo que o leitão leva para alcançar novamente valores de temperaturas normais $\left(39^{\circ} \mathrm{C}\right)$ depende diretamente da temperatura ambiente, do seu 
peso corporal e do momento em que começa a se amamentar (Bäckström \& Curtis, 1981).

$\mathrm{Na}$ Tabela 1, são apresentadas as temperaturas de conforto dos leitões para as diferentes idades.

Tabela 1. Temperatura exigida pelos leitões para as diferentes idades.

\begin{tabular}{cc}
\hline Idade/Semanas & Temperatura $^{\circ} \mathrm{C}$ \\
\hline $0-2$ & $32-30$ \\
$3-4$ & $28-25$ \\
$>4$ & $18-15$ \\
\hline
\end{tabular}

Fonte: Comberg (1966)

\subsubsection{Matrizes}

A ocorrência de estresse térmico durante a lactação pode afetar negativamente a ingestão de alimento, aumentando a perda de peso e a mobilização de gordura corporal, reduzindo a quantidade de leite produzido, aumentando a taxa respiratória e a temperatura retal e comprometendo, consequentemente, o desenvolvimento da leitegada (Thompinks et al., 1967; D`Arce et al., 1970).

Segundo O’Grady et al. (1985), a redução no consumo das matrizes em lactação é da ordem de $0,1 \mathrm{~kg} /$ dia para cada grau centígrado de acréscimo da temperatura ambiente em relação a sua temperatura ótima.

O controle do ambiente interno das instalações deve ser manejado de forma a proporcionar condições ideais e de baixo custo. Deve-se manejar corretamente as cortinas ou janelas para manter a temperatura próximo da zona de conforto, evitando as oscilações térmicas acentuadas e permitindo boa ventilação. Temperaturas muito altas na maternidade prolongam a duração do parto e aumentam a taxa de natimortos, prejudicando o desempenho final da leitegada (Sobestiansky et al., 1998). 


\subsubsection{Leitões}

O leitão recém-nascido possui os sistemas de termorregulação e imunitário pouco desenvolvidos, tornando-se sensível æ̀s temperaturas ambientais baixas. Nessas condições, o leitão reduz sua atividade motora e, consequentemente, diminui a ingestão de colostro, acarretando maior incidência de doenças, maior número de leitões esmagados e alta taxa de refugos na desmama, sendo necessário alguns cuidados especiais. A regra básica é fornecer aos leitões um ambiente limpo, desinfetado, seco e aquecido. Isso significa investir em piso adequado e sistemas de aquecimento (Perdomo et al., 1987).

Durante a vida uterina, a temperatura corporal do leitão é bastante alta e constante, em comparação com a vida extra uterina. Ao nascer, o leitão está neurologicamente bem desenvolvido, porém, fisiologicamente ainda é considerado imaturo e sua capacidade de controlar eficientemente a temperatura corporal está pouco desenvolvida, não podendo compensar imediatamente a intensa perda de calor logo após o parto (Sobestiansky et al., 1998).

Quando a temperatura ambiente é muito baixa, o recém-nascido perde calor e sua temperatura corporal cai rapidamente. Isso se deve não só à incapacidade de regular eficientemente essa temperatura, mas também, ao fato de o leitão apresentar um revestimento de cerdas relativamente esparsas. Esse fato impede o fluxo de calor por meio da piloereção. Além disso, por não possuir a camada de tecido adiposo subcutâneo, que reduz o fluxo de calor desde os vasos sangüíneos até a superfície da pele, a queda da temperatura corporal é acentuada (Simmons, 1976).

A perda de calor logo após o nascimento pode ocasionar:

- $\quad$ aumento da taxa metabólica do leitão, que se deve ao fato de um animal dispor de grande parte de sua produção de energia para manter sua temperatura corporal, em vez de usá-la para o crescimento, acarretando uma pior conversão alimentar. Além disso, essa perda no crescimento também limita o desenvolvimento da gordura, a qual, como camada subcutânea, aumenta o isolamento térmico do animal (Blair et al., 1976)

- $\quad$ morte nas primeiras horas de vida é causada por frio muito severo na ocasião do nascimento, podendo resultar em coma hipotérmico e morte. Isso acontece, 
principalmente, se o leitão permanecer úmido durante muito tempo após o parto (Simmons, 1976).

- aumento da suscetibilidade dos leitões às infecções enterotoxigênicas de Escherichia coli e ao vírus da gastroenterite transmissível. Essa redução da resistência é causada, provavelmente, por mudanças na função imune, induzidas pelo estresse.

- aumento do cortisol no plasma, provocado por baixas temperaturas, é um importante indicador fisiológico, podendo causar essas mudanças na resistência dos leitões æ̀े doenças infecciosas. Dependendo da intensidade da perda de calor, ocorre também morte por hipoglicemia ou predisposição à morte por esmagamento (Kelly, 1982).

\subsubsection{Instalações para maternidade de suínos}

$\mathrm{Na}$ maternidade, o controle das condições ambientais é mais complexo que nas demais instalações. O projeto inicial da maternidade deve atender a microambientes específicos para as matrizes e para os leitões, além de protegê-los contra possível esmagamento. Para evitar o esmagamento, normalmente, são projetadas gaiolas que possibilitam poucos movimentos àfêmea, dotadas de proteções e delimitações de áreas destinadas aos leitões, chamadas escamoteadores.

Para o conforto térmico dos leitões, mantém-se um abrigo escamoteador, vedado e aquecido por meio de lâmpadas ou resistências elétricas, procurando manter no seu interior o índice de temperatura de globo e umidade (ITGU) entre 82 e 84, enquanto na maternidade o ITGU não deve ultrapassar a 72 (Necoechea, 1986). No interior da maternidade, também é necessário um fluxo de ventilação adequado $\left(6 \mathrm{~m}^{3} \cdot \mathrm{s}^{-}\right.$ ${ }^{1}$.animal ${ }^{-1}$ ) para uma velocidade do ar de 0,3 m.s $\mathrm{s}^{-1}$, que possibilite (Morrison et al., 1976; Vaquero, 1981; Scott et al., 1983, Dividich \& Rinaldo, 1989;):

- $\quad$ eliminar o excesso de água do ambiente, proveniente do vapor d'água liberado pela respiração dos animais e dos dejetos;

- $\quad$ renovar o ar viciado, favorecendo a entrada de ar puro;

- $\quad$ eliminar a amônia liberada dos dejetos;

- $\quad$ reduzir a temperatura ambiente; 
- $\quad$ aumentar a dissipação de calor por radiação e convecção pelos animais.

Atualmente, uma prática comum é fornecer um microambiente adequado aos leitões, sem alterar ou prejudicar o bem-estar da matriz em lactação. Esse microambiente é fornecido por meio de uma fonte de calor representada por lâmpadas incandescente ou de infravermelho, suspensas acima do piso. Dependendo da fonte de calor, de sua altura do piso, ou da maneira como é oferecida, o resultado nem sempre é satisfatório, havendo a produção de um ambiente adequado somente numa determinada área, geralmente central, que, freqüentemente, é muito pequena para acomodar toda a leitegada. A altura da fonte de calor em relação ao piso da maternidade deve ser regulada pelo comportamento dos leitões (Sobestiansky et al., 1998).

\subsubsection{Sistemas de controle do ambiente}

Existem alternativas para a redução dos efeitos negativos das altas temperaturas na maternidade. Para tanto, é necessário uma atenção individualizada à matriz, de maneira a protegê-la da exposição æ̀ temperaturas elevadas (Nääs \& Rodrigues, 1999).

Uma das formas efetivas de se conseguirem bons resultados na resposta ao conforto térmico, é o resfriamento localizado. Heard et al. (1986) pesquisaram o efeito da ventilação localizada, próxima à região da cabeça das matrizes, empregando ar resfriado $\left(11^{\circ} \mathrm{C}\right)$ ou sem resfriamento, em 187 matrizes em lactação. Os autores concluíram que ambos os tratamentos promoveram um aumento do consumo alimentar de $5 \%$ e redução da taxa respiratória, sendo o tratamento com ar resfriado o que apresentou maior eficiência, permitindo detectar uma tendência de aumento no ganho de peso dos leitões. A eficiência desse sistema também foi comprovada por Nääs \& Rodrigues (1999).

Estudos na Região Sul do País evidenciaram microambientes mais adequados aos leitões, tendo por objetivo reduzir o consumo de energia elétrica e corrigir as deficiências de manejo relacionadas æ̀ fontes de aquecimento no acondicionamento ambiental de leitões, onde se concluiu que o uso de lâmpadas incandescentes (60 - $100 \mathrm{~W}$ ) no sistema preconizado possibilita uma economia de 
energia de aproximadamente 50\%, quando comparados àresistência elétrica de $150 \mathrm{~W}$, e cerca de $70 \%$ inferior ao consumo de uma lâmpada de infravermelho de $250 \mathrm{~W}$, sem que haja danos ao desempenho dos animais. Outra observação importante é que a utilização de fonte de aquecimento, controlada por termostato, permite manter a temperatura na faixa de conforto e reduz o consumo de energia elétrica, como se pode verificar na Tabela 2

Tabela 2. Temperatura média, máxima e mínima $\left({ }^{\circ} \mathrm{C}\right)$, registradas nos escamoteadores na maternidade.

\begin{tabular}{lccc}
\hline & \multicolumn{3}{c}{ Temperatura no escamoteador $\left({ }^{\circ} \mathrm{C}\right)$} \\
\hline Tratamentos & Máxima & Mínima & Amplitude \\
\hline T1-Escamoteador sem fonte de aquecimento & 22,4 & 15,1 & 7,3 \\
T2-Escamoteador com lâmpada de Infravermelho & 27,2 & 20,2 & 7,0 \\
$\begin{array}{l}\text { controlada pelo criador } \\
\text { T3-Escamoteador como lâmpada de Infravermelho }\end{array}$ & 29,9 & 28,0 & 1,9 \\
$\begin{array}{l}\text { controlada por termostato } \\
\text { T4-Sem escamoteador com lâmpada de Infravermelho }\end{array}$ & 28,0 & 18,6 & 9,4 \\
embutida num prato refletor, controlada pelo criador & & 26,9 & 6,4 \\
Média no escamoteador & 21,6 & 16,2 & 5,4 \\
Média na Maternidade & & & \\
\hline
\end{tabular}

Fonte: Perdomo et al. (1987).

As fontes de calor, quando mal manejadas e, especialmente, quando usadas na ausência de cama, levam à produção de correntes de ar por convecção ocasionadas pelo aquecimento secundário do ar próximo ao piso da maternidade. Dessa maneira, correntes de ar frio passam sobre o leitão, causando perda de calor por convecção.

Com a utilização de escamoteadores, com fonte de calor suplementar, podese reduzir consideravelmente os gastos com eletricidade, adaptando-se um termostato àfonte de calor. Assim, quando a temperatura no escamoteador for atingida, a fonte de calor é desligada automaticamente, e é ligada quando a temperatura baixar novamente.

A Tabela 3 mostra o efeito do escamoteador sobre a mortalidade dos leitões.

Tabela 3. Efeito do escamoteador sobre a mortalidade de leitões. 


\begin{tabular}{lcc}
\hline & $\begin{array}{c}\text { Leitões colocados sobre } \\
\text { aquecedor }\end{array}$ & $\begin{array}{c}\text { Leitões colocados em } \\
\text { escamoteadores }\end{array}$ \\
\hline Número de leitões nascidos & 2358 & 2427 \\
Percentagem de leitões mortos & 5,6 & 2,9 \\
\hline
\end{tabular}

Fonte: Brent (1979).

Estudos realizados por Godbout et al. (2001), comparando a distribuição de radiação e da temperatura de lâmpadas de infravermelho e halogênicas como fontes de aquecimento para leitões em abrigos escamoteadores, mostraram que a temperatura radiante do piso do abrigo, equipado com lâmpada halogênica, variou de 30,3 a $34,5^{\circ} \mathrm{C}$ para uma altura entre $0,60 \mathrm{~m}$ e 0,45 $\mathrm{m}$. Para a lâmpada de infravermelho, os valores foram de 36,5 a $42,7^{\circ} \mathrm{C}$. Além disso, os testes padrões de distribuição da temperatura são diferentes, sendo que a lâmpada de halogênio cobriu um raio de ação maior que o da lâmpada de infravermelho, apresentando uma diferença de temperatura do centro até o limite do diâmetro radiante de $5^{\circ} \mathrm{C}$, ao passo que a infravermelho apresentou uma diferença de aproximadamente $12^{\circ} \mathrm{C}$, para um diâmetro radiante de $60 \mathrm{~cm}$.

Outra possibilidade de fornecer calor suplementar aos leitões de uma maneira uniforme é por meio da instalação de canos para circulação de água quente ou aquecedores elétricos na forma de manta ou embutidos no piso do escamoteador. Em baias com aquecimento embutido no piso, é necessário fornecer calor suplementar por meio de uma lâmpada de infravermelho ou lâmpada incandescente, durante as primeiras 48 horas, para atrair os leitões para a área aquecida (English et al., 1988). Em dias muito frios, mesmo em maternidades com escamoteador, deve-se manter uma fonte suplementar de calor sobre os leitões, durante o parto e nas primeiras horas de vida, para possibilitar maior ingestão de colostro.

McDonald et al. (2000) avaliaram a utilização de mantas térmicas, embutidas no piso do abrigo escamoteador em comparação com a utilização de lâmpadas incandescentes, e verificaram que a eficiência da manta térmica foi superior à apresentada pela lâmpada incandescente, proporcionando uma economia de energia de aproximadamente $50 \%$. Porém, o custo de aquisição do sistema de mantas foi cerca de $70 \%$ superior, com um período de amortização de 1,5 ano, quando comparado àquele de lâmpada incandescente. No que se refere ao desempenho dos 
leitões, quanto ao ganho de peso diário, não se observaram diferenças estatísticas entre os dois sistemas.

$\mathrm{Na}$ suinocultura, muitos criadores ainda não usam mecanismos de proteção do leitão contra o frio. Estudos realizados por Perdomo \& Nicolaiewsky (1988), na Região Sul do Brasil, revelaram que $88 \%$ das edificações amostradas não dispunham de qualquer sistema de proteção do leitão contra o frio. Entretanto, em estudo recente, nessa mesma região, verificou-se que é crescente o número de produtores que utilizam escamoteador com aquecimento para os leitões.

\subsection{Suinocultura de precisão}

Denomina-se Suinocultura de Precisão parte da suinocultura, que emprega o uso de sensores e atuadores para o registro de informações relacionadas ao sistema de produção e as interferências das variáveis ambientais nas unidades produtivas, visando reduzir ou evitar perdas localizadas, propiciando um controle preciso sobre a utilização dos recursos envolvidos na cadeia produtiva. As tecnologias trazem soluções simples e eficientes para grandes problemas, relacionados com o ambiente, manejo de equipamentos e controle de rebanhos na produção industrial de suínos (Pandorfi, 2002).

\subsubsection{Análise de imagem}

A avaliação tradicional do controle do ambiente na produção de animais confinados é baseada principalmente na temperatura do ar. Tal aproximação apresenta problemas inerentes, por não se tratar de um método interativo com as necessidades térmicas dos animais, pois, a temperatura do ar exclusivamente, não representa o ambiente térmico como um todo, o que também inclui variáveis como umidade (especial em circunstâncias quentes), radiação (em instalações mal isoladas), tipo e condição do piso (seco e/ou molhado), variações na condição nutricional e de saúde dos animais.

O conjunto dessas variáveis apresenta a verdadeira caracterização do ambiente dos animais. Contudo, faz-se necessário o registro de todos os fatores 
internos e externos para se produzir um índice detalhado de conforto para a avaliação e o controle de sua produção (Wouters et al., 1990).

Em ambientes agrícolas controlados, tais como as instalações de produção animal, torna-se necessário o uso de técnicas de controle das variáveis ambientais. A prévia detecção de condições prejudiciais ou irregulares são muito importantes, por envolver produtos de valor elevado e o alto custo no sistema de produção. Essas propriedades são controladas geralmente com algum tipo de equipamento local com supervisão humana (Cox, 1988).

Os peritos usam freqüentemente a informação visual dos animais para o diagnóstico, mesmo antes de toda a condição de alarme ser detectada por meio de sensores e instrumentos, que auxiliam na análise da resposta das variáveis, relacionando-as aos dados de produtividade para a detecção de problemas (Xin et al., 1998).

O problema é que, às vezes, o especialista que possa diagnosticar corretamente uma condição anormal pode não estar no local para executar uma análise visual, sendo interessante fornecer o acesso remoto à informação visual em tempo real, sempre que este for necessário. As câmeras de vídeo podem facilmente ser usadas para essa finalidade, fornecendo informações pertinentes ao gerente, proprietário ou a um consultor, para a tomada de decisão (Lopes et al., 2002)

Dusenbery (1985) demonstrou a viabilidade de se observarem, simultaneamente, 25 aves por meio do uso de microcomputador e de uma câmera de vídeo. Nesse trabalho, o autor descreveu a possibilidade de registro individual e simultâneo dos movimentos efetuados por 25 animais, sendo possível obter dados do comportamento dos animais por meio de um equipamento relativamente barato que proporcionou a coleta de imagens em tempo real, por meio do processamento de imagens.

A avaliação e os controles interativos do conforto térmico dos suínos pela análise de imagem superam os problemas inerentes ao método convencional, pois, utilizam-se os próprios animais como um biosensor em resposta aos reflexos do ambiente por meio da análise comportamental (Xin \& Shao, 2002). O sistema consiste em uma microcâmera, uma placa de captura de imagem instalada em um PC e um 
programa visual que executa a aquisição, processamento e a classificação das imagens dos animais (Xin et al., 1998).

Os animais exibem o nível do conforto térmico apresentando comportamentos distintos, ora amontoados, ora agrupados lado a lado ou esparsos. Esses são os padrões de postura dos leitões que se submetem ao frio, ao conforto, e àsensação de calor, respectivamente (Mount, 1968).

Shao et al. (1997) e Shao et al. (1998) relataram os parâmetros comportamentais por imagens, como variáveis de entrada a uma rede neural artificial para a classificação do estado do conforto térmico para suínos, situação de frio, calor e conforto (Mount, 1968).

Dessa forma, o esforço da pesquisa é o de desenvolver um sistema automatizado, em tempo real, pela análise de imagens, que execute a avaliação e o controle contínuo do conforto térmico dos suínos confinados, baseando-se em seus testes padrões de comportamento.

\subsubsection{Identificação eletrônica}

Nas últimas décadas o aumento da produção de suínos, pressionada por uma crescente procura de alimentos, tem-se caracterizado por um aumento no tamanho das unidades produtivas e na concentração de animais em unidades de produção, dificultando o registro dos dados de cada animal em particular. Os sistemas automáticos de identificação eletrônica podem auxiliar na detecção de doenças, resposta fisiológica ao estresse ambiental, ingestão de alimentos, atividade física e o impacto ambiental causado pelo sistema de produção, promovendo melhor controle na propriedade. Transponders injetáveis, brincos eletrônicos e bolus ruminais estão sendo utilizados no processo de identificação eletrônica (Rossing, 1999).

No início dos anos 70, institutos de pesquisas do Reino Unido, Alemanha e dos E.U.A. desenvolveram os primeiros sistemas de identificação eletrônica em animais. $O$ Instituto Nacional de Engenharia Agrícola de Silsoe (Reino Unido) e o Instituto de Engenharia Agrícola em Wageningen (Holanda) desenvolveram um sistema automático de identificação baseado na técnica de modulação de código de pulso (sistema passivo). Esses sistemas de identificação foram construídos com componentes 
convencionais e unidos a um colar em torno do pescoço do animal (Bridle, 1973).Ao mesmo tempo, os laboratórios científicos de Los Alamos (E.U.A.) desenvolveram um sistema eletrônico passivo de identificação com monitoração de temperatura que poderia ser ativado remotamente, transmitindo as informações a um receptor (Holm, 1976). Entretanto, na década de 80, os circuitos integrados especiais foram desenvolvidos de forma a minimizar o tamanho e reduzir o custo dos transponders (Kuip, 1987).

Nos anos 90, as organizações oficiais testaram sistemas para a identificação e o registro de todos os animais domésticos de exploração econômica, para controlar movimentos do nascimento ao abate. Na Holanda, 30\% do rebanho leiteiro já era identificado eletronicamente (Eradus \& Rossing, 1994).

A União Européia preconiza a identificação de todos os animais (bovinos, suínos, caprinos e ovinos) para total controle do nascimento àlinha de abate, definindo um padrão mundial para os dispositivos eletrônicos de identificação, assegurando a compatibilidade entre os sistemas dos diferentes fabricantes, possibilitando, dessa maneira, a ampla projeção do registro e identificação de todos os animais (Wismans, 1999).

\subsubsection{Sistemas de identificação eletrônica}

Seja qual for o dispositivo, um identificador eletrônico possui um transmissor que emite um número de série que permite identificar o animal e monitorar a sua atividade. É possível distinguir os princípios de funcionamento dos diferentes sistemas portadores de informação e reconhecimento, aplicados àidentificação, como mostra a Tabela 4.

Tabela 4. Processos para identificação animal.

\begin{tabular}{|c|c|c|c|c|}
\hline Princípio & Portador de & Aplicação & Vantagens & Desvantagens \\
\hline Operacional & Informação & & & \\
\hline
\end{tabular}




\begin{tabular}{|c|c|c|c|c|}
\hline \multirow[t]{5}{*}{ Ótico } & Forma & $\begin{array}{l}\text { Impressão de } \\
\text { dados }\end{array}$ & $\begin{array}{l}\text { Características } \\
\text { biológicas }\end{array}$ & Requer contato \\
\hline & Cor e Forma & $\begin{array}{l}\text { Reconhecimento } \\
\text { de íris, }\end{array}$ & Universal & Complexo \\
\hline & $\begin{array}{l}\text { Código de } \\
\text { Número }\end{array}$ & $\begin{array}{l}\text { Identificação } \\
\text { Automática }\end{array}$ & Baixo custo & $\begin{array}{l}\text { Complicado, } \\
\text { suja-se } \\
\text { facilmente }\end{array}$ \\
\hline & Código de Barra & $\begin{array}{l}\text { Bens de } \\
\text { comércio, } \\
\text { marcadores } \\
\text { novos de orelha. }\end{array}$ & $\begin{array}{l}\text { Extremamente } \\
\text { barato no } \\
\text { mercado }\end{array}$ & $\begin{array}{l}\text { Suja-se } \\
\text { facilmente }\end{array}$ \\
\hline & $\begin{array}{l}\text { Eletrônicos com } \\
\text { transferência } \\
\text { infravermelha } \\
\text { (ativa) }\end{array}$ & $\begin{array}{l}\text { Equipamentos } \\
\text { eletrônicos, } \\
\text { identificação } \\
\text { animal }\end{array}$ & $\begin{array}{l}\text { Grande escala } \\
\text { de leitura }\end{array}$ & $\begin{array}{l}\text { São possíveis } \\
\text { somente para } \\
\text { os sistemas } \\
\text { ativos }\end{array}$ \\
\hline Eletromecânico & $\begin{array}{l}\text { Ondas } \\
\text { acústicas de } \\
\text { superfície } \\
\text { (passivas) }\end{array}$ & $\begin{array}{l}\text { Identificação de } \\
\text { bens e animais }\end{array}$ & $\begin{array}{l}\text { Elementos do } \\
\text { sensor barato, } \\
\text { rápido. }\end{array}$ & $\begin{array}{l}\text { Somente para } \\
\text { pequenas } \\
\text { informações }\end{array}$ \\
\hline Eletrônico & $\begin{array}{l}\text { Transponder } \\
\text { (ativo e passivo) }\end{array}$ & $\begin{array}{l}\text { Logística, } \\
\text { segurança de } \\
\text { veículo, } \\
\text { identificação } \\
\text { animal }\end{array}$ & $\begin{array}{l}\text { Aplicação } \\
\text { universal }\end{array}$ & $\begin{array}{l}\text { Relativamente } \\
\text { caro. }\end{array}$ \\
\hline
\end{tabular}

Fonte: Artmann (1999).

A aplicação da identificação eletrônica por meio de transponders passivos no controle da suinocultura permite, por exemplo, controlar automaticamente a quantidade de ração que um suíno ou outro animal qualquer devidamente identificado recebe. Existem tipos de comedouro que impedem o acesso de mais de um animal 
simultaneamente. Quando um animal se aproxima do comedouro, ele impede a entrada de outros. O comedouro possui um receptor que identifica o número do animal dentro do comedouro. Essa combinação entre transmissor e receptor só funciona a uma distância curta, quando o animal se aproxima do comedouro para comer (Goedseels, 1992).

O receptor cria um campo eletromagnético (campo de ativação), que é usado pelo transponder para gerar a própria voltagem operacional como uma fração de freqüência de ativação, emitindo um sinal e comparando o número do animal com uma base de dados que contém registrados todos os animais da granja (Artmann, 1999). Com base nesses dados e na hora do dia, o comedouro libera uma determinada quantidade de ração específica para aquele animal e atualiza a base de dados, permitindo controlar a quantidade de ração consumida por cada animal.

Uma fazenda experimental da Universidade do Estado de lowa combinou um sistema de alimentação com a identificação eletrônica de matrizes em gestação, em um rebanho não confinado, permitindo à porca exercitar-se durante o período de gestação e conviver em grupos sociais, porém mantendo o controle do fornecimento de ração e ganho diário de peso, quando comparados a duas formulações distintas. $\mathrm{O}$ sistema de alimentação eletrônico torna-se de grande eficiência quando os animais são alojados em grupos, controlando a necessidade nutricional de cada matriz, evitando comportamentos agressivos dentro do rebanho e garantindo controle do peso, assegurando a máxima produtividade e aumentando a longevidade do rebanho (Hoff, 1998)

Devido à natureza dos suínos, o uso de transmissores externos pode ser pouco aconselhável, pois os animais tendem a danificá-los. O local de aplicação dos transponders deve ser de fácil acesso, permitindo maior eficiência no processo de identificação e remoção, de modo que não ocorram danos na carcaça. Em geral, a área da cabeça é recomendada como melhor local de aplicação dos transponders, sejam eles fixados como etiquetas visuais, e/ou brincos nas orelhas. Com auxílio de um injetor com uma agulha oca, os transponders podem ser injetados debaixo da pele do animal (Artmann, 1999).

O uso de transmissores pode ser mais interessante no caso de animais de reprodução, que permanecem mais tempo na propriedade. Além do sistema do 
consumo de ração, o sistema também pode ser usado para registrar as cobrições, vacinações, nascimentos, desmames, ou seja, a ocorrência de eventos em geral. Com registros adequados, as cobrições mais recomendáveis podem ser especificadas, em função do grau de parentesco dos animais e da data de utilização do macho. Informações semelhantes podem ser utilizadas para inseminação artificial (Fialho, 1999).

A modernização da suinocultura levou a produção de suínos a altos níveis de eficiência, fazendo com que aumentos subsequentes na produtividade sejam progressivamente mais difíceis, tornando-se necessário o uso de técnicas cada vez mais sofisticadas, para promover o incremento na produção.

\subsubsection{Identificação com transponders injetáveis}

O sistema de identificação eletrônica com transponders injetáveis é um processo promissor para melhorar o atual sistema de marcação de suínos, como o sistema australiano, tatuagens e brincos, que apesar de serem de fácil aplicação e baixo custo, apresentam várias desvantagens, como a visibilidade, o risco de perdas e eventuais manipulações.

O transponder injetável é uma peça especialmente desenhada para a identificação de animais, sendo encapsulado com vidro biocompatível, de maneira a não apresentar rejeição pelo organismo e de dimensões muito pequenas $(11,5 \times 2,2$ $\mathrm{mm}$ ). Dessa forma, um animal microchipado iria carregar sua identificação digital do nascimento até o abate, sendo possível todo o acompanhamento de seu crescimento e desenvolvimento, realizado por meio de leitores manuais ou antenas estrategicamente colocadas na propriedade.

Por outro lado, os transponders injetáveis cumprem exigências importantes para seu uso na prática. Os principais aspectos são a compatibilidade biológica, viabilidade de injeção, desempenho técnico e, finalmente, o procedimento de recuperação em abatedouros comerciais, para evitar qualquer risco para cadeia alimentícia humana (Klindtworth et al., 1999). 


\subsection{Tolerância biológica do transponder no animal}

A injeção subcutânea de um transponder ocasiona dano de pequenas partes da epiderme e derme, ou reações no corpo do animal, que poderiam ser resultado de movimentos migratórios do microchip, Lambooy ${ }^{1}$, citado por Artmann (1999).

\subsubsection{Biocompatibilidade}

Embora a pele seja constituída por uma complexa estrutura composta por tecido conjuntivo, folículos de pêlo, glândulas e vasos sangüíneos, Malibach \& Rovee (1972) afirmam que a cura de feridas é caracterizada por uma quase perfeita regeneração da epiderme em aproximadamente uma semana e a derme em aproximadamente 3 semanas. Com base nessa experiência, é esperado que a cura da ferida, após a injeção de um transponder, seja bastante rápida.

Arndt \& Wiedemann ${ }^{2}$, citados por Klindtworth et al. (1999), concluíram que microchips aplicados de maneira correta e com total assepsia não apresentaram nenhuma infecção ou rejeição, pelo fato dos transponders injetáveis serem encapsulados dentro de um tubo de vidro biocompatível, que separa o implante do tecido anfitrião, permanecendo ao redor do transponder durante todo o período de vida do animal, sem sofrer nenhuma alteração.

\subsubsection{Migração}

As migrações são aspectos críticos para o uso de transponders, podendo ser um risco para alguns órgãos essenciais. Além disso, podem causar dificuldades na linha de abate, na recuperação dos microchips, quando estes não estão localizados no local esperado.

\footnotetext{
${ }^{1}$ LAMBOOY, E. Das Injizieren eines Transponders in den Tierkörper zur Identifikation. In: Petersen, B., Welz, M. (Eds.), Beiträge zur Tagung EDV - Anwendung in der Herden-und Gesundheitskon-trolle, Oktober 1990, Bonn. In: Agrarinformatik, v.20. Eugen Ulmer Verlag, Stuttgart, p. 18-22.

${ }^{2}$ ARNDT, J.; WIEDEMANN, C. Zusammenfassung von Verträglichkeitprüfungen mit Transpondern des elektronischen Markierungssystems INDEXL. Kleintierpraxis, v.36, p.381-389, 1991.
} 
Para avaliar a migração do transponder em relação ao local de aplicação, são utilizadas várias metodologias como radiografias, dissecação do cadáver para posterior cálculo da distância de migração, usando pontos orgânicos de referência, sendo bastante difícil comparar os poucos resultados disponíveis, como os diferentes locais de implante usados em diferentes espécies, Lambooy \& Merks (1989).

Por exemplo, Lambooy \& Merks (1989) conduziram um experimento em que se implantaram transponders ao lado da parte de trás da orelha em 11 leitões. Posteriormente, na linha de abate, eles só encontraram três dos transponders no local original de injeção, outros quatro foram localizados na mandíbula e alguns foram achados até mesmo próximos da coluna espinal.

Em pesquisas desenvolvidas na Faculdade de Engenharia Agrícola (UNICAMP), Campinas, SP, analisando-se o melhor local para o implante do microchip em aves, matrizes pesadas, em relação à unidade de leitura (antena), localizada no piso, a região do pescoço não apresentou um volume de dados satisfatório, além de ter ocorrido a migração do transponder. Portanto, o melhor local para o implante está entre o pé e a coxa do animal (Pereira et al., 2001).

Roma Júnior, et al. (2002), avaliando diferentes locais de inserção do microchip no organismo de frangos de corte, verificou que os melhores locais para aplicação, ou seja, os locais de menor migração, foram a crista, pescoço e pata. Porém, os locais que apresentaram maior migração foram na coxa e no peito.

Em recentes estudos, realizados com o objetivo de verificar os locais mais indicados para o implante dos microchips em leitões, demonstraram que, na região da cartilagem da base da orelha, houve maior facilidade de aplicação, ótima aceitabilidade pelo animal, além de se mostrar dentro de limites aceitáveis de movimentação no corpo do animal. Para os outros dois locais adotados, na fossa infraorbital e nos dígitos da pata, apesar de não observarem problemas de migração, foi constatado um efeito de rejeição ao implante. Nos dígitos da pata, houve dificuldade na aplicação, devido ao tipo de tecido encontrado nesse local, onde também se observou maior sensibilidade do animal, apresentando posteriormente dificuldade ao caminhar (Pandorfi et al., 2002).

Silva et al. (2002), testando diferentes locais de implante de microchip em suínos, utilizando antena painel, constatou que o melhor local foi na base da orelha, por apresentar fácil aplicação e menor contato, evitando perdas e desgastes ocasionados 
pelas atividades dos animais.

Fatores como idade dos animais e tamanho dos transponders, mostraram influência significativa na migração. Com o avanço da idade dos animais e o tamanho dos implantes, houve uma diminuição dos movimentos observados, embora, não se possa afirmar uma interação positiva entre ambos os fatores de acordo com Kern ${ }^{3}$, citado por Klindtworth et al. (1999). Apesar desses fatores de influência terem sido mencionados, o autor afirma que migrações de no máximo $6 \mathrm{~cm}$, podem ser assumidas como não críticas, pois ainda estão na região próxima à inserção do microchip, esperando-se que seja localizado sob condições normais na linha de abate.

Diante disso, os resultados encontrados por Pandorfi et al. (2002), Roma Jr, et al. (2002), Silva et al. (2002), estão dentro dos limites apontados em 1997 por Kern ${ }^{3}$.

3 KERN, C. Technische Leistungsfähigkeit und Nutzung von injizierbaren Transpondern in der Riderhalltung. Dissertation, TU München-Weihenstephan, 1997. 


\section{MATERIAL E MÉTODOS}

A pesquisa foi realizado na granja Querência, propriedade cuja principal atividade é a produção industrial de suínos, localizada no município de Elias Fausto, SP, apresentando latitude de $22^{\circ} 36^{\prime} \mathrm{S}$, longitude de $47^{\circ} 36 \mathrm{~W}$ ' e altitude de $532 \mathrm{~m}$, o clima da região é caracterizado como mesotérmico Cwa (tropical de altitude), com temperatura do mês mais frio entre -3 e $18^{\circ} \mathrm{C}$, com inverno seco e temperatura do mês mais quente maior que $22^{\circ} \mathrm{C}$, segundo classificação Köppen (Pereira et al., 2002).

O desenvolvimento da pesquisa foi na sala da maternidade, no período compreendido entre o nascimento e o desmame dos leitões, com duração média de 19 dias, de acordo com o manejo adotado nessa produção. A fase experimental foi dividida basicamente em duas etapas:

Etapa 1 - Período de verão (de fevereiro a março de 2002).

Etapa 2 - Período de inverno (de junho a agosto de 2002).

\subsection{Tratamentos}

$\mathrm{Na}$ pesquisa, foi avaliada a eficiência de 4 sistemas de aquecimento nos abrigos escamoteadores, constituindo-se os seguintes tratamentos (Figura 1, 2, 3, 4):

- Tratamento 1: Abrigo escamoteador equipado com piso térmico de placas prémoldadas de compósitos biomassa vegetal-cimento aquecido por meios de resistência elétrica, confeccionadas no Laboratório de Ensaios de Materiais, da Faculdade de Engenharia Agrícola da Unicamp, com dimensões de 0,40 x 0,50 m, compondo um conjunto de 3 placas por abrigo, como se pode observar na Figura 1 (Rossi, et al., 2002). 


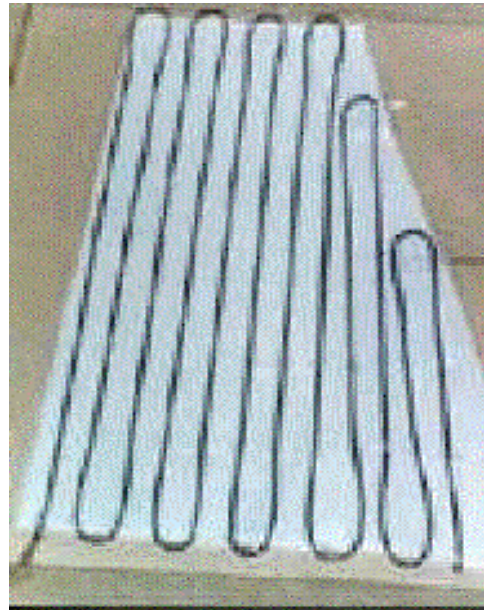

Figura 1 - Piso térmico de compósitos biomassa vegetal-cimento aquecido por meio de resistência elétrica.

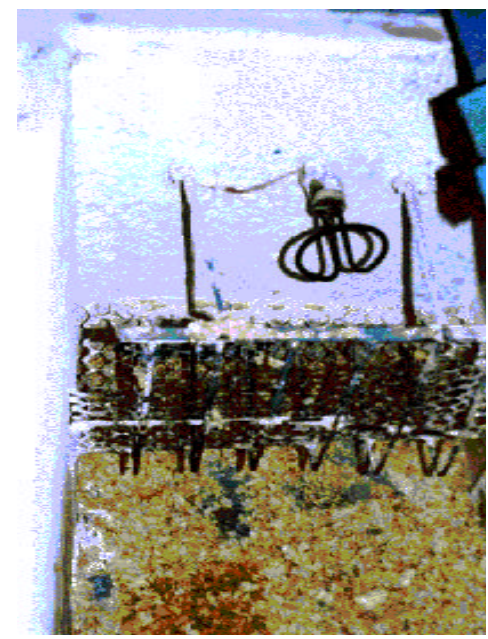

Figura 3 - Escamoteador equipado com resistência elétrica (200W).

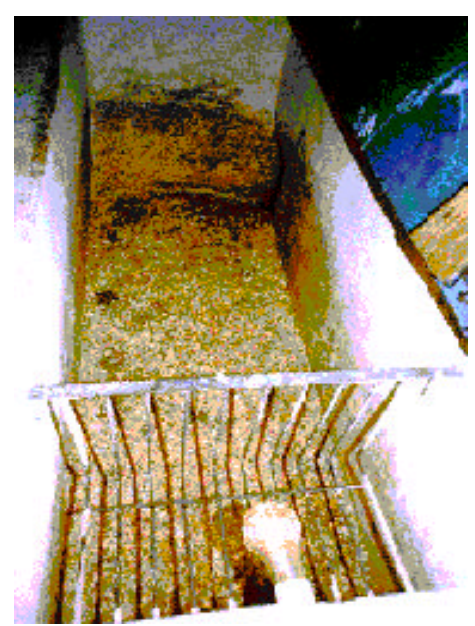

Figura 2 - Abrigo escamoteador equipado com lâmpada incandescente (200W).

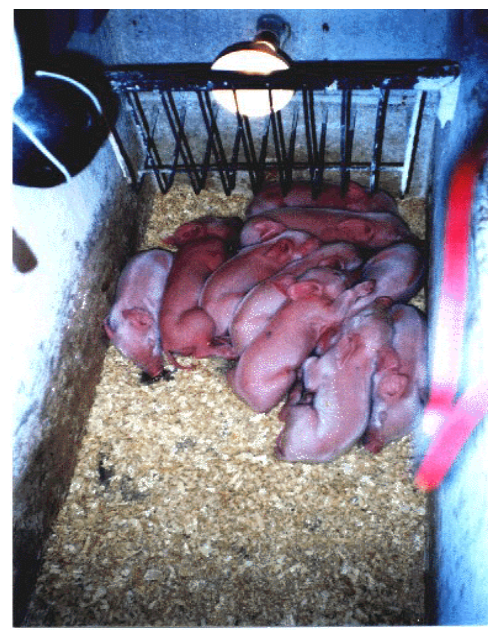

Figura 4 - Abrigo escamoteador equipado com lâmpada de infravermelho (250W).

- Tratamento 2: Abrigo escamoteador equipado com lâmpada incandescente de 200W, fixada na parede de uma das extremidades do abrigo, a uma altura de $0,50 \mathrm{~m}$ do piso (Figura 2).

- Tratamento 3: Abrigo escamoteador equipado com resistência elétrica de 200W, fixada na parede de uma das extremidades do abrigo, a uma altura de $0,50 \mathrm{~m}$ do piso (Figura 3). 
- Tratamento 4: Abrigo escamoteador equipado com lâmpada de infravermelho de 250W, fixada na parede de uma das extremidades do abrigo, a uma altura de $0,50 \mathrm{~m}$ do piso (Figura 4).

\subsection{Tipologia das instalações estudadas}

Os abrigos escamoteadores possuem as dimensões de $1,50 \mathrm{~m}$ de comprimento por $0,55 \mathrm{~m}$ de largura, por $0,65 \mathrm{~m}$ de altura, totalizando uma área de 0,82 $\mathrm{m}^{2}$, e um volume de $0,53 \mathrm{~m}^{3}$. Toda área de piso foi coberta por uma cama de maravalhas, e os sistemas de aquecimento foram controlados manualmente, de acordo com o manejo adotado pela granja, ou seja, eram acionados æ̀ 20 horas e desligados às 7 horas, no período de verão. Durante o período de inverno, os sistemas de aquecimento permaneceram acionados durante todo o período experimental.

A sala da maternidade é caracterizada tipologicamente por $23,0 \mathrm{~m}$ de comprimento por $13,5 \mathrm{~m}$ de largura e pé direito de 2,8 $\mathrm{m}$, forro revestido com placas de poliestireno, acompanhando a face inferior do telhado. Cobertura com telhas de cerâmica do tipo francesa, sendo que ao longo da sala, a instalação apresenta 8 janelas de cada lado, com peitoril de 1,50 m e uma altura de 1,3 $\mathrm{m}$, totalizando uma área de abertura de janelas de $90 \mathrm{~m}^{2}$.

O manejo das cortinas laterais foi realizado concomitantemente com o acionamento dos sistemas de aquecimento dos abrigos escamoteadores, ou seja, fechavam-se as cortinas durante o aquecimento (manejo de verão). No inverno, as cortinas permaneceram praticamente o tempo todo fechadas, sendo abertas somente nos horários mais quentes do dia.

Foram alojadas na sala 34 matrizes, em 34 celas parideiras, orientadas no centro de cada baia. As baias possuíam dimensões de 1,7 $\mathrm{m}$ de largura por 2,8 $\mathrm{m}$ de comprimento e 1,2 m de altura, totalizando $4,76 \mathrm{~m}^{2}$. As celas parideiras $\mathrm{e}$ as respectivas matrizes foram selecionadas aleatoriamente, de acordo com o desenho esquemático na Figura 5. 


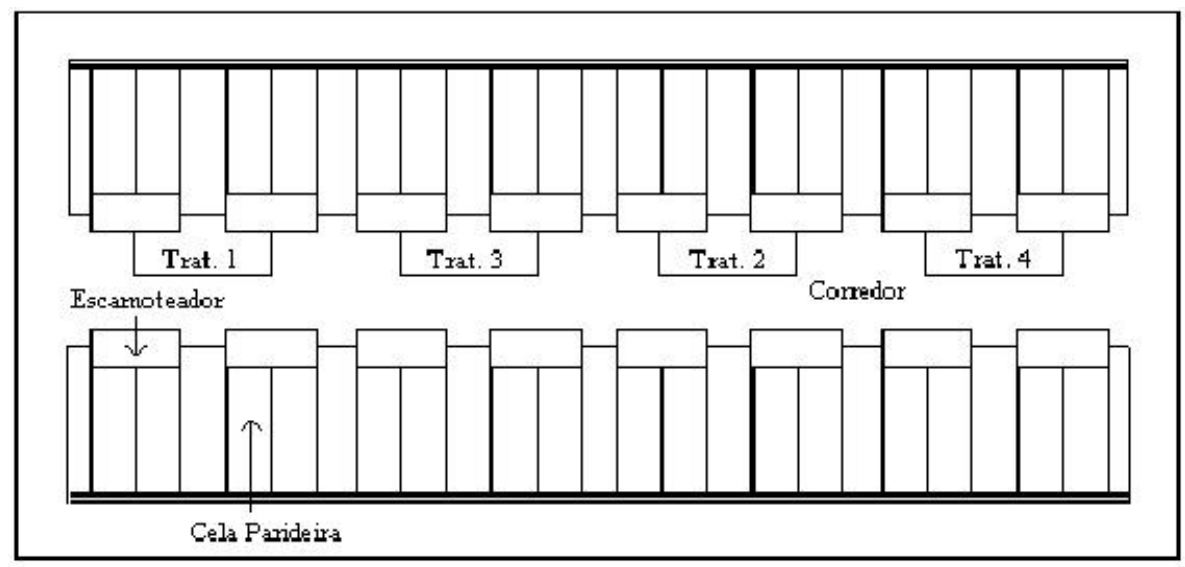

Figura 5 - Esquema geral da distribuição dos tratamentos na maternidade.

\subsection{Animais do estudo}

O estudo foi realizado com animais híbridos threecross (Landrace $x$ Large Whirte $x$ Duroc). Os leitões que fizeram parte do estudo eram de matrizes de mesma ordem de parto, selecionadas com o objetivo de eliminar fatores de interferência, habilidade materna, número de leitões/leitegada. Para etapa de verão, foram selecionadas matrizes de $1^{\mathrm{a}}$ ordem, e para o inverno, matrizes de $6^{\mathrm{a}}$ ordem, de acordo com a disponibilidade de animais, com previsão de parto em cada etapa experimental. Cada baia apresentou 10 leitões que, após os partos, foram remanejados por critério de peso e número de animais/leitegada de modo que todos os abrigos estudados permaneceram com um número fixo de 10 leitões.

\subsection{Análise de dados}

\subsubsection{Variáveis resposta do microambiente}

Durante as duas etapas do experimento, foram monitoradas as variáveis ambientais no abrigo escamoteador, na sala da maternidade e no ambiente externo. Foram registradas por meio de sensores conectados a uma plataforma automática de 
coleta de dados, as seguintes variáveis: temperatura de bulbo seco (Ts), temperatura de bulbo úmido (Tu), temperatura de globo negro (Tg) e velocidade do vento (VV).

O registro dos dados de temperatura foi realizado em intervalos de 15 minutos, durante os 18 primeiros dias de vida dos leitões, período em que os animais permaneceram na maternidade. Os sensores para a obtenção da temperatura eram compostos por uma rede de cabos termopares do tipo T (cobre-constantan).

A determinação da velocidade do vento (VV) foi realizada manualmente com auxílio de um termo-anemômetro da marca Testo, modelo 405-V1, com intervalo de uma hora, das 7:00 æ̀̀ 18:00 horas.

Nos abrigos escamoteadores, os sensores, para determinação da Ts, Tu e $\mathrm{Tg}$, foram acoplados na tampa dos abrigos escamoteadores, distando 0,55 $\mathrm{m}$ do piso (Figura 6).

$\mathrm{Na}$ sala da maternidade as variáveis ambientais foram registradas no interior da instalação, na região central das baias estudadas, a uma altura de 1,3 m do piso (Figura 7).

Na área externa às instalações, os sensores foram instalados no interior de um abrigo meteorológico, a 1,5 m de altura da superfície, representando o microclima do local (Figura 8).

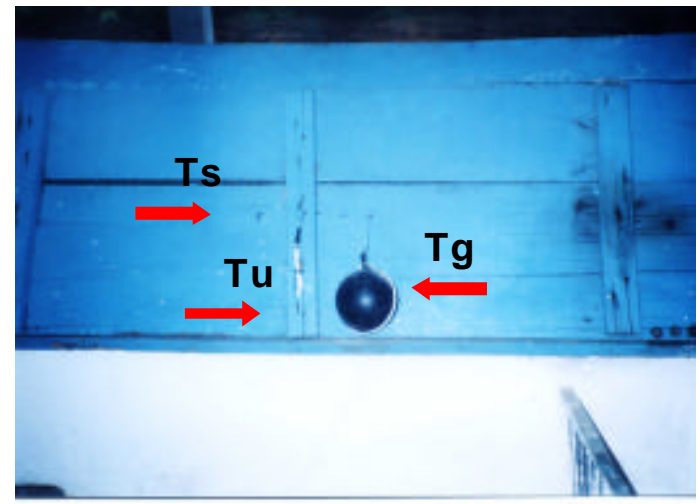

Figura 6 - Sensores acoplados na tampa do abrigo escamoteador.

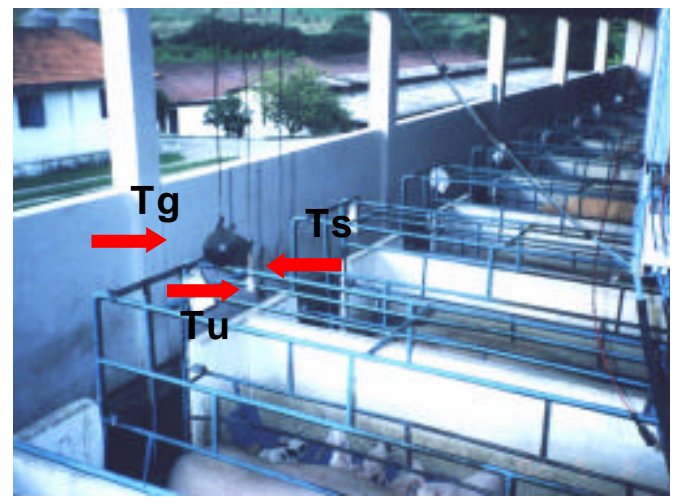

Figura 7 - Disposição dos sensores no interior da sala da maternidade. 


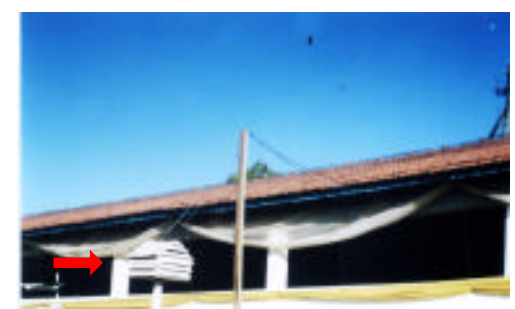

\section{Ts Tu Tg}

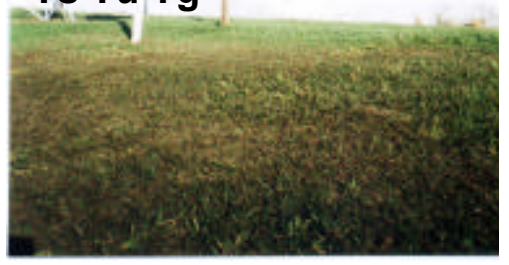

Figura 8 - Abrigo meteorológico instalado no ambiente externo, próximo à sala da maternidade.

Na segunda etapa da pesquisa (inverno), além das variáveis ambientais foram também registradas as variações de temperatura do piso, de todos os abrigos escamoteadores envolvidos no estudo, visando àidentificação do perfil da temperatura na área do abrigo, em relação ̀̀ diferentes fontes de aquecimento. $O$ registro dos dados foram realizados manualmente, em intervalos de 4 horas, no período das 8 æ̀ 20 horas, totalizando 4 observações diárias. A representação das isotermas foi realizada por meio do software geoestatístico "surfer".

O registro da temperatura do piso foi realizado em 9 pontos, de acordo com a representação esquemática da Figura 9.

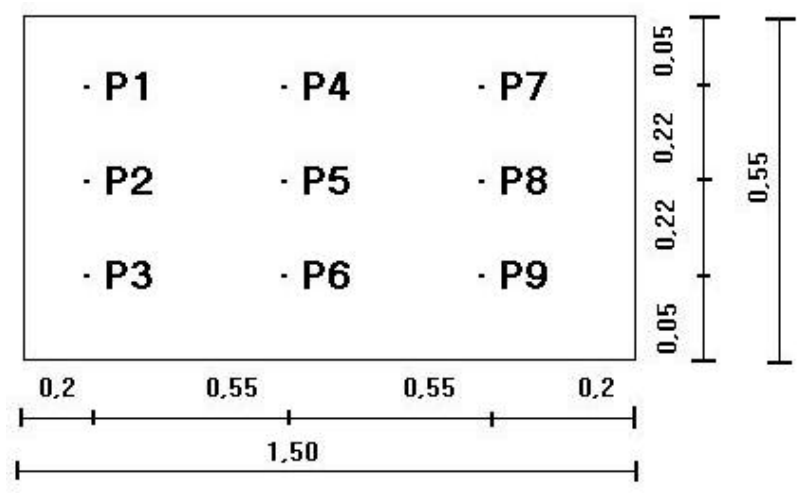

Figura 9 - Representação esquemática dos pontos de medida de temperatura de piso nos abrigos escamoteadores. 


\subsubsection{Avaliação das variáveis ambientais}

Para determinação da eficiência térmica em cada tratamento, com os dados de temperatura dos ambientes estudados, foram determinados o índice de temperatura de globo e umidade (ITGU), carga térmica radiante (CTR) e entalpia $(\mathrm{H})$ por meio das seguintes equações:

a) índice de temperatura de globo e umidade (ITGU), proposta por Buffington et al.(1981):

$$
I T G U=T g+0,36 T p o-330,08
$$

Em que:

$\mathrm{Tg}=$ temperatura de globo negro $(\mathrm{K})$

Tpo = temperatura de ponto de orvalho $(\mathrm{K})$

b) do índice de carga térmica radiante (CTR), proposta por Esmay (1982):

$$
\begin{gathered}
C T R=\tau(T M R)^{4} \\
T R M=100\left\{\left[2,51(V V)^{0,5}(T g-T S)+\left(\frac{T g}{100}\right)^{4}\right]^{0,25}\right\}
\end{gathered}
$$

Em que:

$T R M=$ temperatura média radiante.

$V V=$ velocidade do vento $(\mathrm{m} / \mathrm{s})$;

$T g=$ temperatura de globo negro $(\mathrm{K})$;

$T s=$ temperatura de bulbo seco $(\mathrm{K})$;

$\tau=5,67^{*} 10^{-8} \mathrm{~K}^{-4} \cdot \mathrm{W} \cdot \mathrm{m}^{-2}$ (Constante de Stefan-Boltzmann). 
c) entalpia (kJ/kg ar seco), proposta por Albright (1990):

$$
H=1,006 T s+W(2501+1,805 T s)
$$

Em que:

Ts = temperatura de bulbo seco $\left({ }^{\circ} \mathrm{C}\right)$

$W=$ razão de mistura (kg vapor d'água/kg ar seco)

\subsubsection{Avaliação zootécnica}

A análise dos parâmetros zootécnicos dos animais foi realizada adotando-se as metodologias convencionais para o registro de ganho de peso e mortalidade. Os parâmetros avaliados foram:

- Ganho de peso: Os leitões foram pesados no dia do nascimento e no desmame. 0 ganho de peso diário (GPD) foi obtido dividindo-se o ganho total de peso pelo número de dias em que os animais permaneceram na maternidade, de acordo com a equação apresentada abaixo:

$$
G P D=\frac{G P P}{N D}
$$

\footnotetext{
Em que:

GPD = ganho de peso diário (kg/dia);

GPP = ganho de peso do período $(\mathrm{kg})$;

$\mathrm{ND}=$ número de dias que os animais permaneceram na maternidade.
}

- Mortalidade: Foi registrado o número de óbitos diários, durante o período em que os animais permaneceram na maternidade. 


\subsubsection{Avaliação das variáveis comportamentais}

O ponto fundamental desta pesquisa é justamente a avaliação dos sistemas de aquecimento, usando a análise comportamental dos animais, para compreensão da eficiência do sistema em função da sensação do conforto animal.

$\mathrm{Na}$ etapa 1 (período de verão) da pesquisa utilizou-se, como ferramenta para registro desses dados, a identificação eletrônica por imagem, por meio de microcâmeras instaladas no interior de cada abrigo escamoteador.

Foram utilizadas microcâmeras preto e branco com lente de 2,45 mm e "leds" de infravermelho, o que permitiu obter as imagens nos abrigos onde não havia fontes de luz, no caso dos abrigos equipados com piso térmico e resistência elétrica.

As imagens registradas foram analisadas com o objetivo de verificar a freqüência de uso e o tempo de permanência dos animais no abrigo, permitindo verificar a descrição do comportamento dos animais dentro do abrigo em função dos sistemas de aquecimento e das variáveis ambientais envolvidas no estudo.

As imagens foram registradas diariamente em intervalos de 2 minutos, sendo gerenciadas pelo software "videocap", armazenando as informações num banco de dados para posterior análise.

A análise das imagens foram realizadas para três dias críticos, considerados nessa pesquisa como os dias de menor entalpia do período, segundo Moura et al. (1997). Deve-se considerar que, por se tratar de aquecimento, adotou-se a menor entalpia como crítica, por considerar a menor quantidade de calor presente em uma parcela de ar seco.

$\mathrm{Na}$ etapa 2 (período de inverno), além do sistema de monitoramento pelas microcâmeras, utilizou-se a identificação eletrônica dos animais, por meio de transponders e antenas, possibilitando o registro comportamental dos leitões, e a avaliação da eficiência das ferramentas aplicadas na pesquisa. Foram utilizados transponders passivos da marca Trovan, com as dimensões de 11,5 x 2,12 mm. Estes foram aplicados por meio de uma agulha oca, subcutaneamente, na região da inserção inferior da base da orelha, de acordo com os resultados encontrados por Pandorfi et al. (2002), que pode ser observado na Figura 10. 


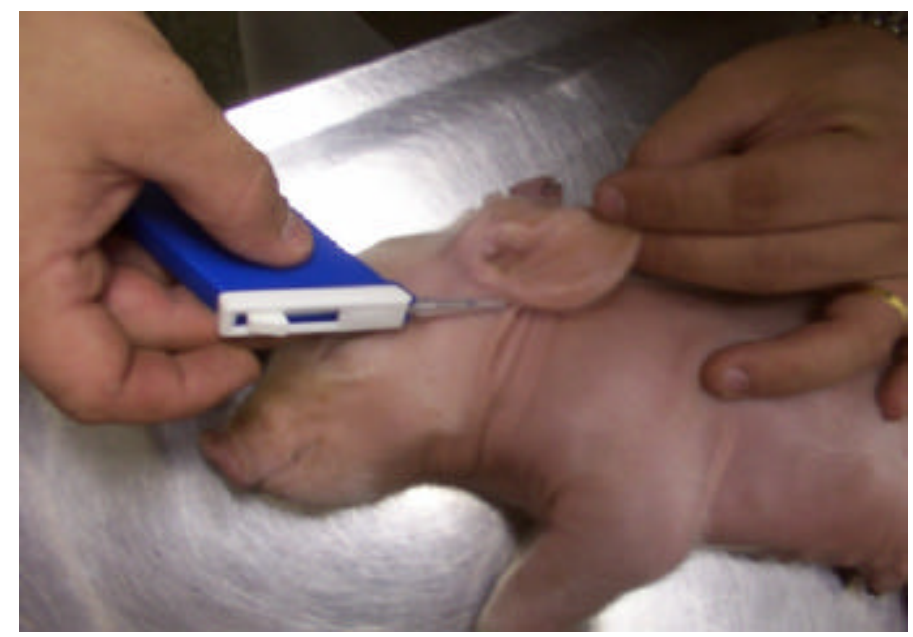

Figura 10 - Aplicação do transponder na região da inserção da base da orelha.

Todos os animais foram identificados eletronicamente, em todos os tratamentos.

O uso da microeletrônica aplicada àprodução animal, enquadra-se na temática da zootecnia de precisão. Dessa forma, os equipamentos utilizados para esta etapa da pesquisa podem ser observados nas Figuras 11 e 12.

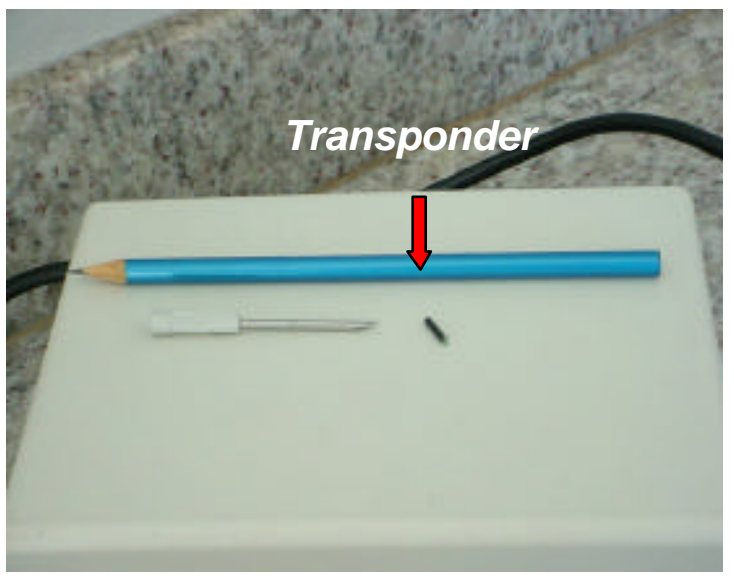

Figura 11 - Detalhe do microchip utilizado na identificação eletrônica dos animais.

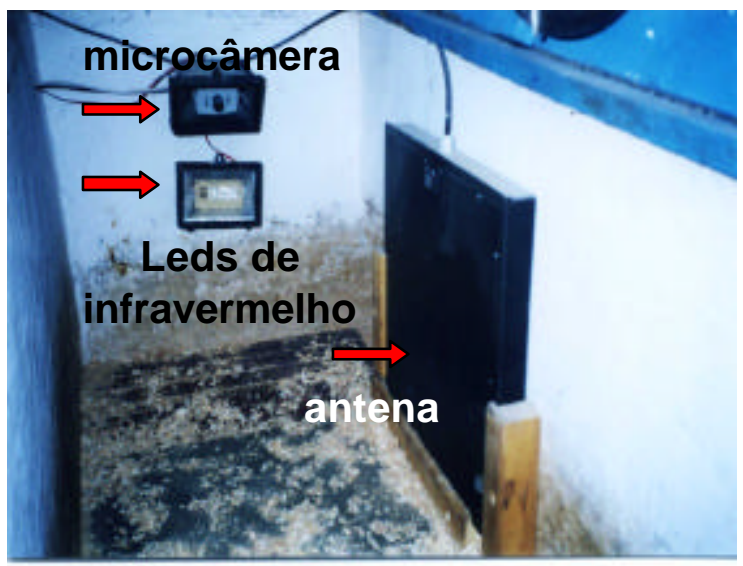

Figura 12 - Microcâmera, leds de infravermelho e antena de captação do sinal dos microchips, instalados no interior do abrigo escamoteador. 
A identificação eletrônica permitiu o registro do tempo de permanência dos animais dentro do escamoteador, favorecendo a validação do sistema de identificação eletrônica por meio das análises de imagem.

\subsection{Análise técnico-econômica}

A realização da análise técnico-econômica foi realizada registrando 0 consumo de energia (Kwh) dos diferentes sistemas de aquecimento, com o auxílio de medidores (relógios), verificando-se o consumo total no período em que os leitões permaneceram na maternidade (19 dias), em função do manejo diferenciado em cada etapa estudada. A relação custo benefício foi determinada de acordo com o custo do kWh, e o ganho de peso do animal, associando com o custo da carne suína.

\subsection{Delineamento experimental}

Foi utilizado o delineamento em blocos casualizados (DBC), adotando-se 4 tratamentos e 18 blocos, considerando os blocos como os números de observações diárias estudadas no experimento (Tabela 5). As médias das variáveis resposta dos microambientes foram comparadas pelo teste de Tukey $(P<0,05)$. Toda a análise estatística foi realizada por meio do programa estatístico "Statistical Analysis System" (SAS, 1992).

Tabela 5. Análise da variância utilizada na pesquisa.

\begin{tabular}{cc}
\hline C.V. & G.L. \\
\hline Blocos & 17 \\
Tratamentos & 3 \\
Resíduo & 51 \\
Total & 71 \\
\hline
\end{tabular}


Foi realizada uma análise de correlação, para comparação entre as temperaturas externas (abrigo meteorológico) em função da temperatura na sala da maternidade.

Para descrição do comportamento, freqüência de utilização dos locais monitorados, foi realizada uma análise de correlação entre o número de animais e a temperatura de bulbo seco na sala da maternidade. 


\section{RESULTADOS E DISCUSSÃO}

\subsection{Análise dos dados de verão}

\subsubsection{Análise das variáveis ambientais e a eficiência térmica dos sistemas de aquecimento para leitões}

\subsubsection{Análise geral}

Para os dados referentes àtemperatura na sala da maternidade e no abrigo meteorológico (ambiente externo), foram ajustadas equações, utilizando-se análise de regressão, envolvendo valores médios horários da temperatura no ambiente externo em função da temperatura na sala da maternidade. As retas de ajuste 1:1, apresentaram uma tendência de variação linear, apresentando valor de $R^{2}(0,6327)$, significativo a $1 \%$ de probabilidade pelo teste $\mathrm{F}$, verificando-se variação média, de aproximadamente 5,2\% superior na sala da maternidade (Figura 13). Considerando-se que a instalação apresenta uma área de abertura $\left(90 \mathrm{~m}^{2}\right)$, a temperatura do ambiente no seu interior é influenciada pelas diferentes variáveis que atuam no meio, determinada pela temperatura no ambiente externo, temperatura radiante das superfícies, taxa de renovação de ar, equipamentos e presença dos animais, promovendo a elevação da temperatura no interior da sala da maternidade. 


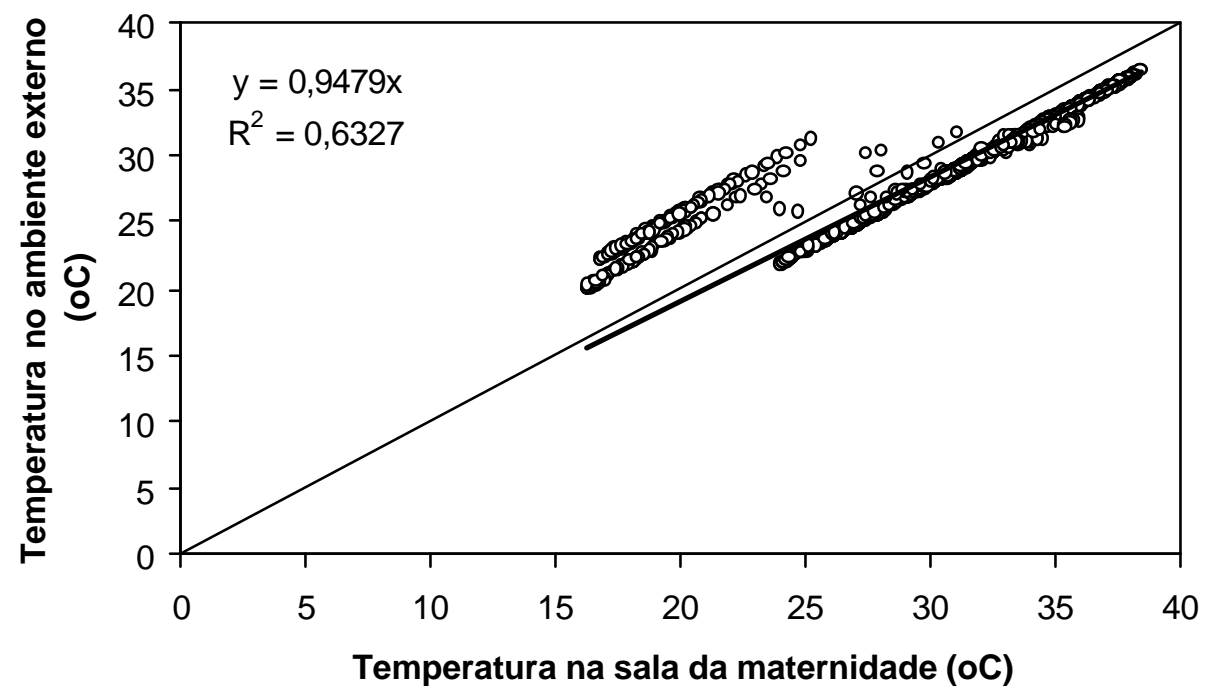

Figura 13 - Representação da correlação entre temperatura na sala da maternidade e no abrigo meteorológico (ambiente externo), na etapa de verão, envolvendo todos os dados coletados.

A comparação entre tratamentos, apresentados na Tabela 6, são os resultados médios diários das variáveis resposta nos microambientes estudados, abrigos escamoteadores e seus sistemas de aquecimento respectivamente. Verificouse que os tratamentos apresentaram diferenças significativas para temperatura de bulbo seco (Ts) e temperatura de globo negro (Tg), quando comparados entre si, apesar dos tratamentos lâmpada incandescente e resistência elétrica não diferirem estatisticamente. Esse fato pode ter ocorrido em virtude desses tratamentos apresentarem a mesma potência de funcionamento (200W), promovendo semelhante condicionamento no interior dos abrigos equipados com os respectivos aquecedores, ou seja, a dissipação de energia no tempo é a mesma para os ambientes estudados.

Tabela 6. Valores médios diários das variáveis ambientais observadas no abrigo 
escamoteador durante a permanência dos leitões na maternidade, na etapa de verão.

\begin{tabular}{lccc}
\hline Etapa de verão & $\operatorname{Ts}\left({ }^{\circ} \mathrm{C}\right)$ & $\operatorname{Tg}\left({ }^{\circ} \mathrm{C}\right)$ & UR $(\%)$ \\
\hline Piso térmico & $32,4 \mathrm{c}$ & $32,5 \mathrm{c}$ & $79,5 \mathrm{a}$ \\
Lâmpada incandescente & $35,8 \mathrm{~b}$ & $35,4 \mathrm{~b}$ & $63,6 \mathrm{~b}$ \\
Resistência elétrica & $35,5 \mathrm{~b}$ & $35,5 \mathrm{~b}$ & $62,2 \mathrm{~b}$ \\
Lâmpada de infravermelho & $38,0 \mathrm{a}$ & $38,2 \mathrm{a}$ & $53,6 \mathrm{c}$ \\
\hline
\end{tabular}

Valores médios com letras diferentes, na mesma coluna, diferem estatisticamente pelo pelo Teste de Tukey, $\mathrm{P}<0,01$.

A Figura 14 evidencia o efeito dos diferentes sistemas de aquecimento na temperatura do interior dos abrigos escamoteadores. Nessas condições, verifica-se que o aquecimento proporcionado aos leitões, está acima da condição recomendada, $32^{\circ} \mathrm{C}$ na primeira semana de vida, reduzindo-se posteriormente $2^{\circ} \mathrm{C}$ por semana até os 21 dias (Esmay, 1982; Perdomo et al., 1987; Nääs, 1989; Silva, 1999), ficando evidente que o uso de aquecimento com as características estudadas é desnecessário para essa localidade no verão, sendo que a própria condição na sala já está atendendo a necessidade de temperatura para os leitões, sendo suficiente o correto manejo das cortinas laterais.

Reforçando a afirmação citada acima, pode-se observar na Figura 15, a variação das temperaturas mínimas diárias. Esses resultados demonstram que a condição de conforto, na primeira semana de vida dos animais, é atendida no interior da própria instalação e no abrigo equipado com piso térmico. Nas duas semanas posteriores, essa condição praticamente se mantém, para o tratamento com piso térmico, pois, as necessidades térmicas dos animais se encontram mais próximas das faixas de conforto nesse microambiente.

Nos outros tratamentos adotados, a temperatura se encontra durante todo a fase avaliada, acima da temperatura crítica superior (TCS), atingindo valores da ordem de 38,34 e $33^{\circ} \mathrm{C}$, para $1^{\mathrm{a}}$, $2^{\mathrm{a}}$ e $3^{\mathrm{a}}$ semana, respectivamente (Mount, 1968; Curtis, 1983; Silva, 1999), promovendo condições inadequadas, em que os animais submetidos a esses ambientes passariam a sofrer estresse calórico. 


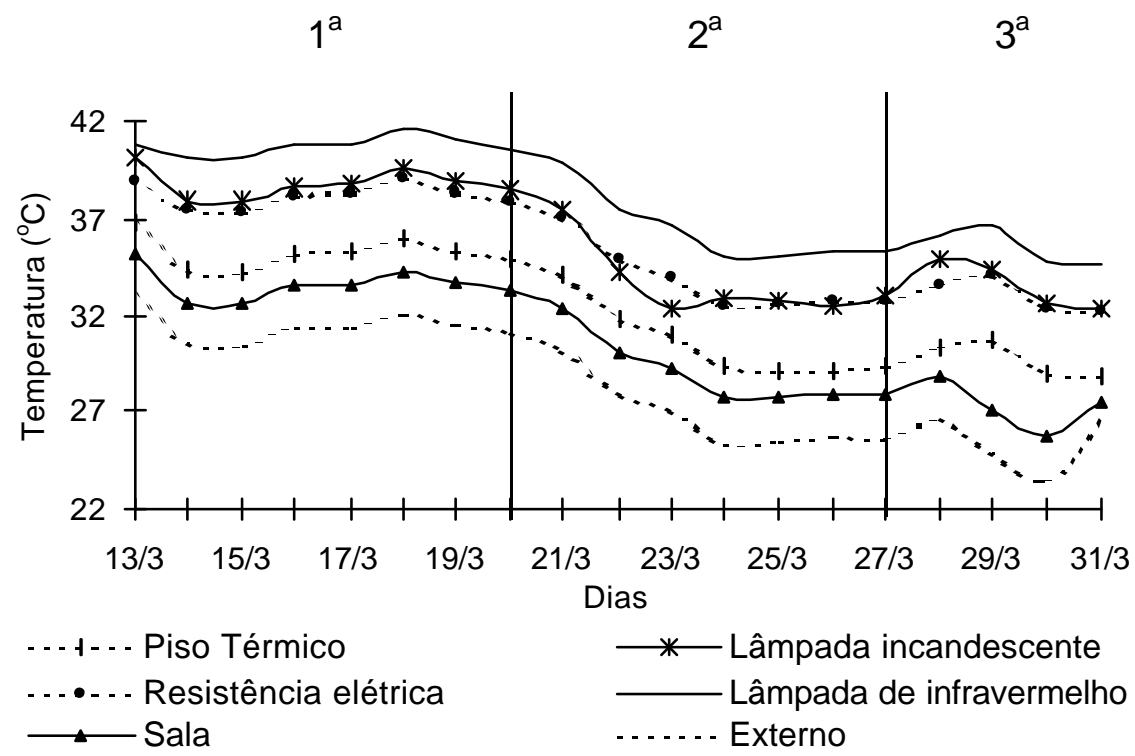

Figura 14 - Variação da temperatura média diária na etapa de verão nos diferentes tratamentos na sala da maternidade e no abrigo meteorológico (ambiente externo).

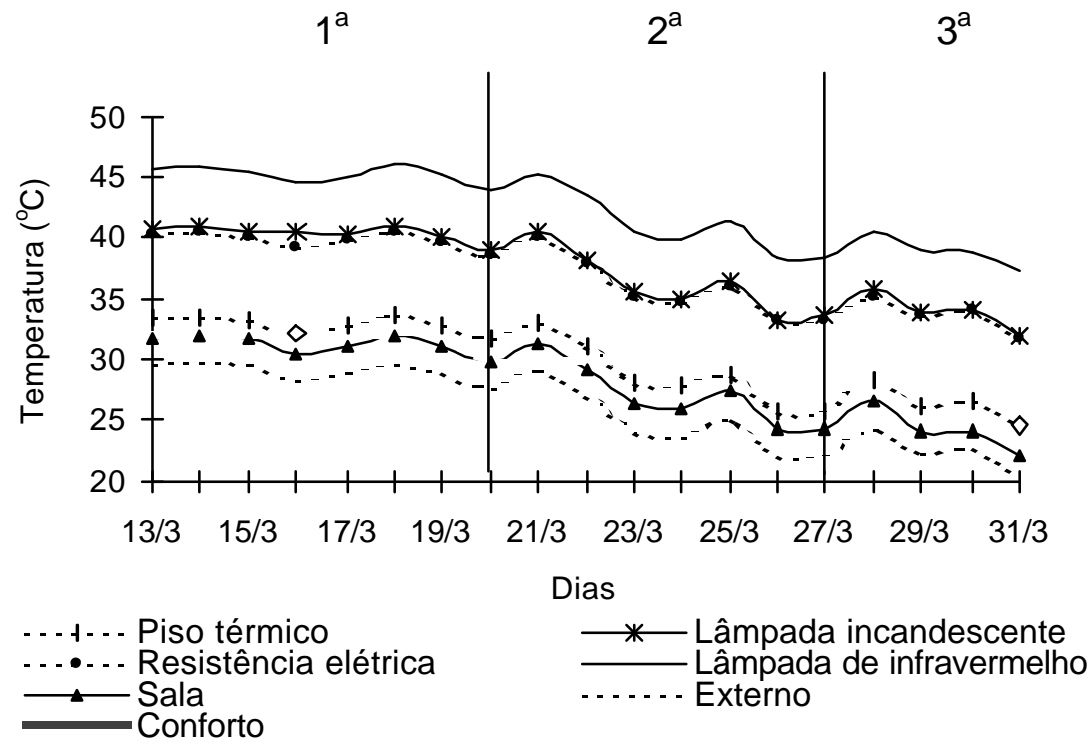

Figura 15 -Variação da temperatura mínima diária na etapa de verão nos diferentes tratamentos, sala da maternidade, abrigo meteorológico (ambiente externo) e conforto. 
Para uma melhor visualização dos resultados, adotou-se a metodologia da adoção dos dias críticos para essa condição de produção, ou seja, períodos mais frios são considerados dias críticos, para leitões. Portanto, foram selecionados os dias com menor entalpia em cada semana da fase de crescimento dos animais, durante a fase da maternidade, segundo metodologia proposta por Moura et al. (1997).

Diante do exposto, pode-se verificar que a Figura 16 apresenta curvas interrompidas, pois, referem-se aos dias críticos de 18/03, 24/03 e 29/03, respectivamente.

Nos horários em que os sistemas de aquecimento foram acionados no período das 20 às 7 horas, o piso térmico manteve a temperatura no interior do abrigo o mais próximo da faixa de conforto dos leitões, durante toda fase de verão. Para os outros tratamentos, a temperatura se apresentou sempre acima da condição adequada, de $32^{\circ} \mathrm{C}$ na $1^{\mathrm{a}}$ semana, $30^{\circ} \mathrm{C}$ na $2^{\mathrm{a}}$ e $28^{\circ} \mathrm{C}$ na $3^{\mathrm{a}}$ semana de vida dos leitões.

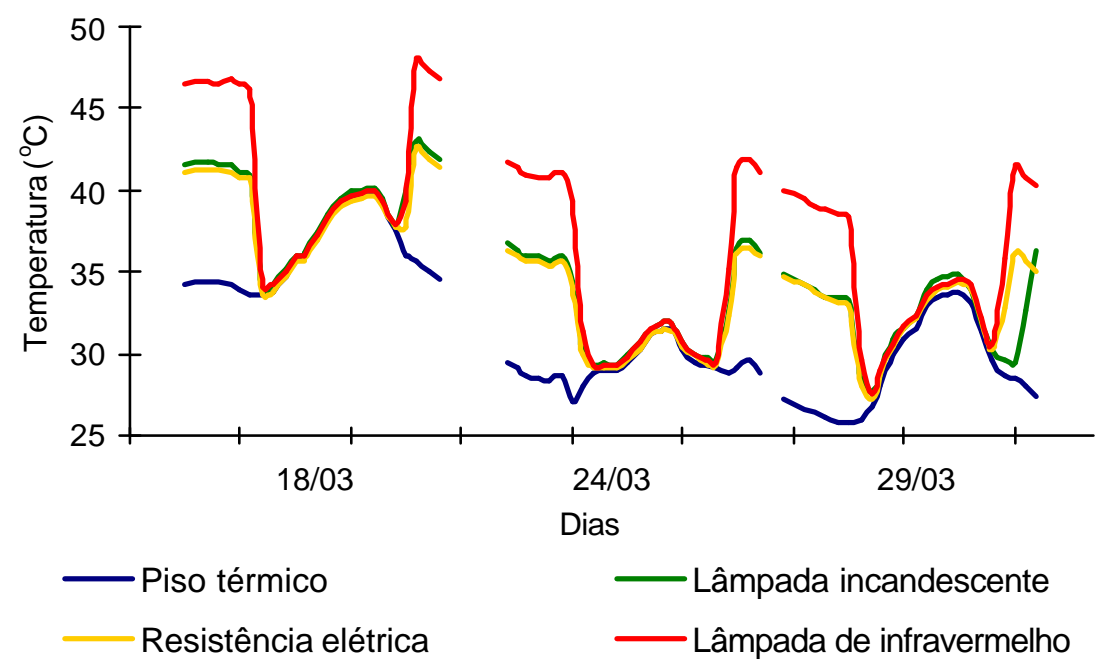

Figura 16 - Variação da temperatura para os dias de menor entalpia na etapa de verão nos diferentes tratamentos avaliados.

Com relação a $\mathrm{Tg}$, os valores registrados para os diferentes sistemas de aquecimento estudados apresentaram o mesmo comportamento da Ts, devido à pequena variação apresentada entre as respectivas variáveis ambientais.

A variação da umidade relativa, no interior dos escamoteadores, apresentou 
diferenças significativas, principalmente no abrigo equipado com lâmpada de infravermelho, que além de promover altas temperaturas, reduziu significativamente a umidade relativa no seu interior. O volume de ar se contrai e/ou expande com a variação da temperatura, essa variação de volume impõe um limite àquantidade de vapor d'água que pode ser retida pelo volume de ar, ou seja, quanto maior a temperatura, maior a quantidade saturante de vapor d'água. Nessas condições, a tendência de variação diária da umidade relativa do ar está relacionada ao fato de que a pressão parcial de vapor (ea) varia pouco durante o dia, mas a pressão de saturação de vapor (es) varia exponencialmente com a temperatura do ar. Assim, a UR terá tendência de evolução inversa à da temperatura, verificando-se baixos valores de UR para essa situação.

Com relação ao tratamento piso térmico, a energia térmica radiante, proveniente do piso, não foi suficiente para promover redução da UR, nos níveis verificados nos demais tratamentos, apresentando valores próximos à condição na sala da maternidade (Figura 17).

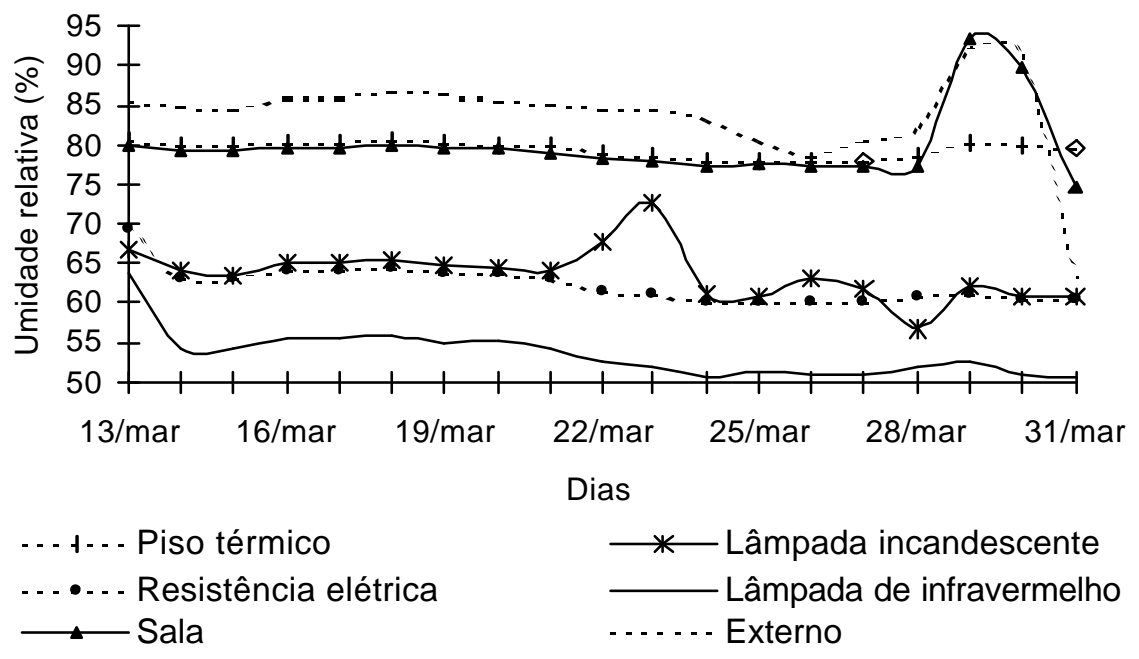

Figura 17 - Variação da umidade relativa média diária na etapa de verão nos diferentes tratamentos na sala da maternidade e no abrigo meteorológico (ambiente externo). 


\subsubsection{2 Índices de conforto térmico}

Os valores médios diários de ITGU, CTR e $\mathrm{H}$, correspondentes à primeira etapa (verão), para os tratamentos avaliados, estão apresentados na Tabela 7.

Tabela 7. Valores médios dos índices de conforto, ITGU, CTR e H, observados na primeira etapa (verão), durante a permanência dos leitões na maternidade.

\begin{tabular}{lccc}
\hline Fase de verão & ITGU & CTR $\left(\mathrm{W} / \mathrm{m}^{2}\right)$ & $\mathrm{H}(\mathrm{kJ} / \mathrm{kg}$ ar seco $)$ \\
\hline Piso térmico & $83,9 \mathrm{c}$ & $494,2 \mathrm{c}$ & $98,2 \mathrm{c}$ \\
Lâmpada incandescente & $86,6 \mathrm{~b}$ & $512,1 \mathrm{~b}$ & $99,8 \mathrm{a}$ \\
Resistência elétrica & $86,4 \mathrm{~b}$ & $513,4 \mathrm{~b}$ & $97,1 \mathrm{~d}$ \\
Lâmpada de infravermelho & $89,1 \mathrm{a}$ & $532,2 \mathrm{a}$ & $99,3 \mathrm{~b}$
\end{tabular}

Valores médios com letras diferentes na mesma coluna, diferem estatisticamente pelo pelo Teste de Tukey, $\mathrm{P}<0,01$.

O índice de temperatura de globo e umidade (ITGU) apresentou valores médios para lâmpada incandescente e resistência elétrica, que não diferiram estatisticamente. O menor valor de ITGU foi verificado para o tratamento piso térmico, e o maior valor encontrado foi para lâmpada de infravermelho, apresentando diferenças estatísticas (Tabela 7).

Considerando-se o dia de menor entalpia, nas $1^{\mathrm{a}}, 2^{\mathrm{a}}$ e $3^{\mathrm{a}}$ semanas avaliadas, pode-se observar na Figura 18 que a variação do ITGU para o abrigo equipado com piso térmico foi o que apresentou valores mais próximos do ideal, 82 a 84 (Necoechea, 1986), para toda fase estudada, nos horários em que os sistemas estavam acionados. Os abrigos equipados com lâmpada de infravermelho, resistência elétrica e lâmpada incandescente, apresentaram valores acima do recomendado. 


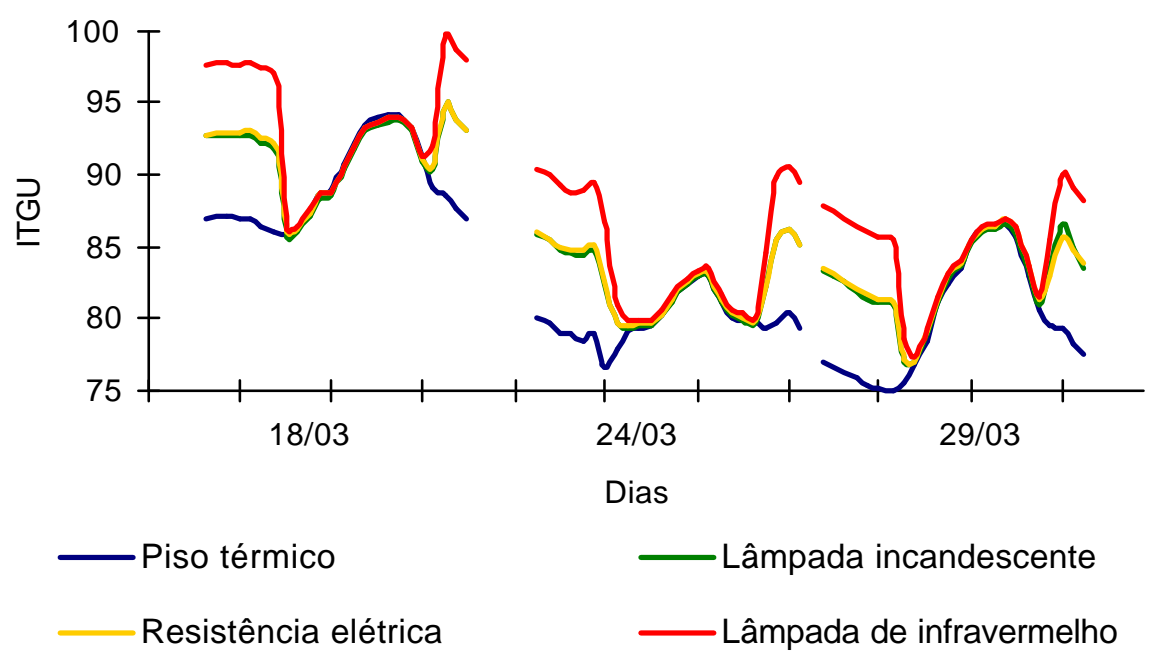

Figura 18 - Variação do índice de temperatura de globo e umidade para os dias de menor entalpia na etapa de verão nos diferentes tratamentos avaliados.

Os maiores valores de CTR foram observados para o tratamento com lâmpada de infravermelho. Os tratamentos lâmpada incandescente e resistência elétrica não apresentaram diferenças significativas quando comparadas. Porém, o tratamento piso térmico foi o que apresentou menor valor de CTR, diferindo-se estatisticamente dos demais (Tabela 7). Além das fontes de aquecimento, atribui-se aos altos valores da CTR no interior dos abrigos, o fato de ser um ambiente pequeno, vedado, com baixa velocidade de circulação de ar $(0,03 \mathrm{~m} / \mathrm{s})$.

Comparando-se a CTR de cada tratamento, para os dias considerados críticos, dias de menor entalpia, verifica-se pequena variação entre eles, porém, todos os tratamentos apresentaram valores superiores a $450 \mathrm{~W} / \mathrm{m}^{2}$, valor esse, considerado suficiente para o aquecimento dos leitões (Baêta \& Souza, 1997). Em virtude dos valores apresentados, presume-se que a utilização de aquecedores com uma menor disponibilidade de energia térmica radiante seja mais adequado para essa situação (verão) (Figura 19). 


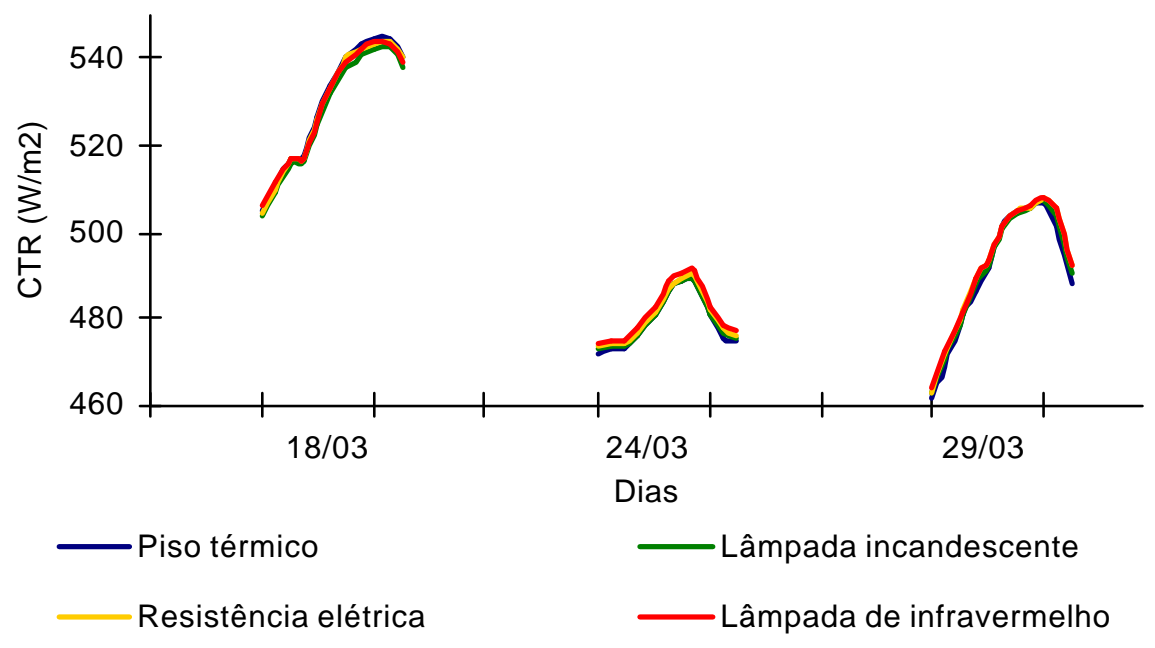

Figura 19 - Variação da carga térmica radiante para os dias de menor entalpia na etapa de verão nos diferentes tratamentos avaliados.

Para os valores médios da entalpia $(\mathrm{H})$, os resultados apontaram diferenças estatísticas em todos os tratamentos estudados, sendo que o maior valor verificado foi para o abrigo equipado com lâmpada incandescente, lâmpada de infravermelho, piso térmico e resistência elétrica, respectivamente (Tabela 7).

Esse fato ocorreu justamente devido à quantidade de energia interna da parcela de ar (calor sensível + calor latente), nos microambientes avaliados, em relação à soma de suas componentes, de uma mistura de ar seco e vapor d'água, levando-se em consideração a Ts $\left({ }^{\circ} \mathrm{C}\right)$ e a razão de mistura (kg de vapor d'água/kg de ar seco).

Verifica-se na Figura 20, que a variação da entalpia nos tratamentos adotados foi muito similar, estando sempre acima da condição ideal, valores estimados em 90,2; 81,6 e $73,8 \mathrm{~kJ} / \mathrm{kg}$ ar seco, para condição de conforto de 32,30 e $28^{\circ} \mathrm{C}$, e umidade relativa de $70 \%$, segundo (Silva, 1999), para $1^{\mathrm{a}}, 2^{\mathrm{a}}$ e $3^{\mathrm{a}}$ semana de vida dos leitões respectivamente.

Para certificar-se das informações citadas acima, procurou-se representar as condições entálpicas mínimas verificadas nessa etapa, como se pode observar na Figura 21. As determinações das condições mínimas de entalpia foram realizadas, utilizando-se a temperatura mínima diária na sala da maternidade durante o período de 
verão.

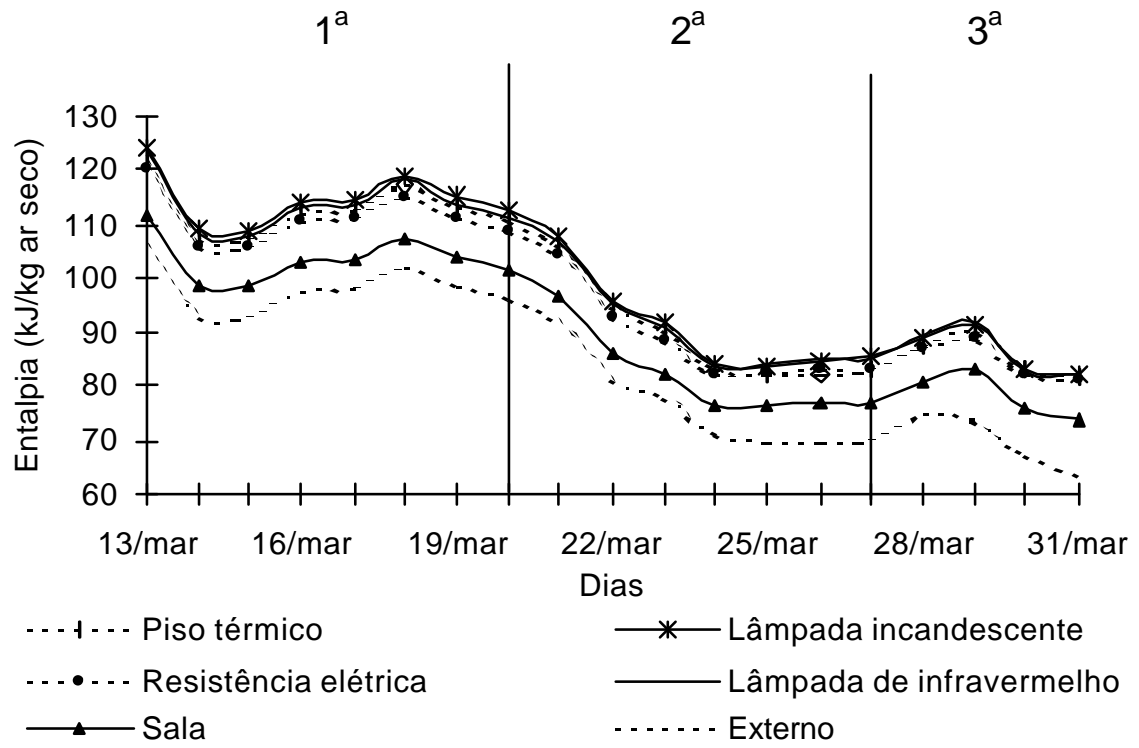

Figura 20 - Variação da entalpia média diária na etapa de verão nos diferentes tratamentos na sala da maternidade e no abrigo meteorológico (ambiente externo).
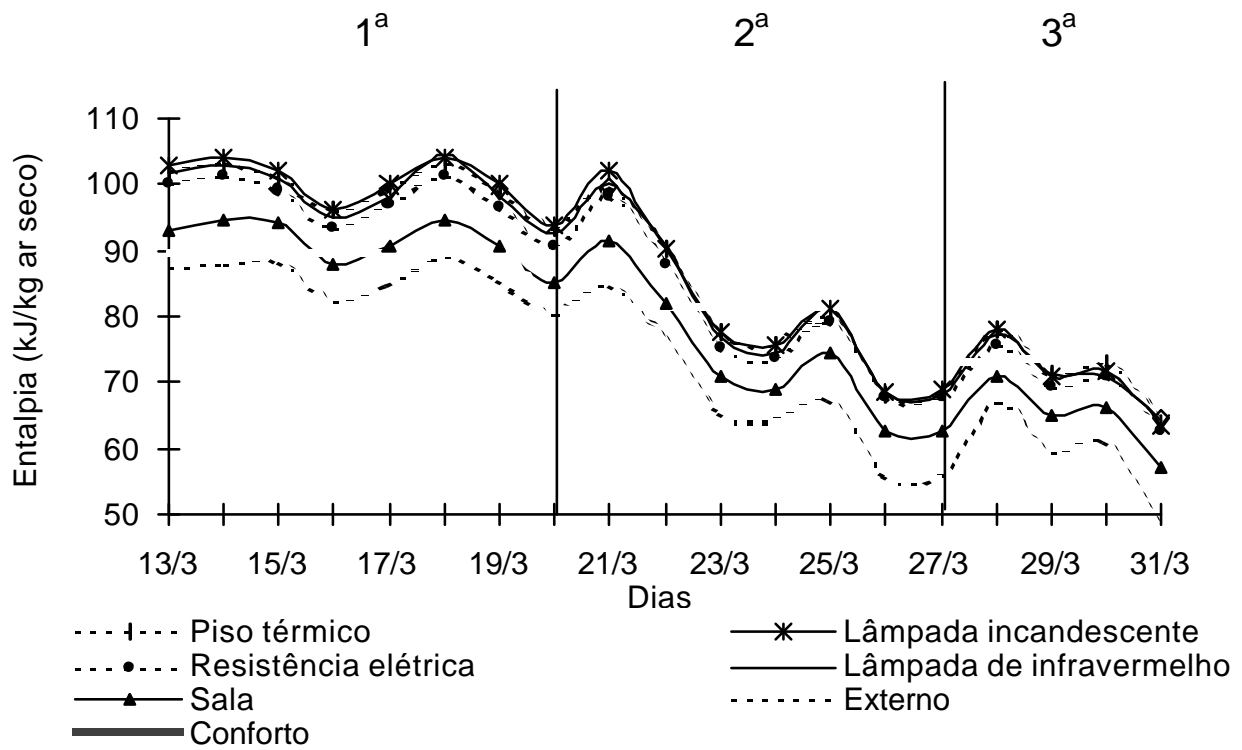

Figura 21 - Variação da entalpia mínima diária na etapa de verão nos diferentes tratamentos na sala da maternidade e no abrigo meteorológico (ambiente externo). 
Os valores de entalpia mínima diária, obtidas no decorrer desta etapa, revelam que, para a $1^{\text {a }}$ semana avaliada, não há necessidade de aquecimento para os leitões, visto que o ambiente externo e a sala da maternidade apresentam níveis adequados de conforto aos animais.

Para as duas semanas subseqüentes, nota-se que os sistemas de aquecimento contribuem efetivamente para a manutenção da condição conforto dos animais, verificando-se apenas um ponto (28/03), que superou a condição ideal, para os tratamentos, lâmpada incandescente, resistência elétrica e lâmpada de infravermelho. O uso de fontes de aquecimento, controladas por termostato, permite corrigir essas deficiências de manejo, promovendo um melhor controle dessas flutuações de variação.

\subsubsection{Avaliação comportamental dos leitões no verão}

\subsubsection{Freqüência de acesso dos leitões ao abrigo escamoteador}

Deve-se considerar que, para análise da freqüência de acesso dos leitões ao abrigo escamoteador, analisaram-se os 3 dias considerados críticos do período. Dessa forma, baseando-se no tempo de permanência dos animais dentro dos abrigos, observado na Tabela 9, selecionou-se o dia 29/03/02 para análise individual e horária da freqüência de acesso.

O contraste entre a freqüência de acesso e a variação da temperatura na sala da maternidade, ao longo do dia selecionado (29/03), representando o dia de menor temperatura e maior acesso dos leitões ao abrigo, representado pela porcentagem de animais no interior do mesmo, verifica-se na Figura 22 (a), que os animais expostos ao abrigo escamoteador com o piso térmico utilizaram o abrigo com maior freqüência no intervalo das 5 æ̀ 9 horas, período em que se observa menor temperatura na sala da maternidade, comprovando que, quanto menor a temperatura da sala, maior freqüência de acesso ao escamoteador.

Os mesmos resultados foram encontrados para os diferentes sistemas de aquecimento, o que pode ser observado nas Figuras 22 (b), 22(c) e 22 (d). Deve-se ressaltar que, quando a temperatura na sala da maternidade se eleva, a freqüência de 
acesso diminui.

Verifica-se, também, nas Figuras 22 (b) e 22 (d), que a porcentagem de animais no interior dos abrigos é reduzida, evidenciando-se que em alguns tipos de aquecimento estudados, a resposta é mais evidente, como é o caso da lâmpada incandescente e lâmpada de infravermelho, superando a necessidade térmica dos animais.

Deve-se ressaltar ainda que, além da potência de funcionamento das fontes de calor, a eficiência de aquecimento varia em função da altura de instalação do aquecedor, para os leitões, preconiza-se uma altura de 0,60 $\mathrm{m}$ do piso, variando de acordo com o comportamento dos animais (Godbout et al., 2001). Para os tratamentos lâmpada incandescente, resistência elétrica e lâmpada de infravermelho, encontramse a $0,50 \mathrm{~m}$ de altura do piso, promovendo altas temperaturas, na região mais próxima do animal.

Na Figura 22 (c), verifica-se a freqüência de uso do escamoteador equipado com resistência elétrica, apresentando comportamento intermediário, quando comparado ao piso térmico, evidenciando o efeito da menor entalpia $(85,7 \mathrm{~kJ} / \mathrm{kg}$ ar seco), observado neste caso (Tabela 9).

Com relação as freqüências de uso apresentadas nas Figuras 22 (a), (b), (c) e (d), observa-se que são coerentes com as variações da temperatura e da entalpia encontrados na avaliação térmica dos ambientes.

Devido ao fato da lâmpada de infravermelho aquecer excessivamente o ambiente, verifica-se uma redução na freqüência de uso desse abrigo. Dessa forma, quando se analisa a freqüência no escamoteador com piso térmico, nota-se a maior incidência de animais no mesmo. Resultado similar a esse, também foi encontrado por McDonald et al. (2000), avaliando a eficiência de manta térmica e sistemas convencionais de aquecimento, atestando o melhor desempenho do aquecimento proveniente do piso (manta térmica).

Para os outros tratamentos adotados, verificou-se que a permanência dos animais nos mesmos foram superiores para os períodos em que os sistemas de aquecimento ficaram desligados, 7 æ̀s 20 horas (13 horas/dia), caracterizando a baixa procura dos abrigos no período em que o aquecimento era acionado, 20 æ̀ 7 horas (10 horas/dia), em virtude das altas temperaturas proporcionadas no interior dos mesmos, 
sendo possível obter o condicionamento ambiental ideal para os leitões, preconizandose a utilização de fonte de aquecimento, controlada por termostato.

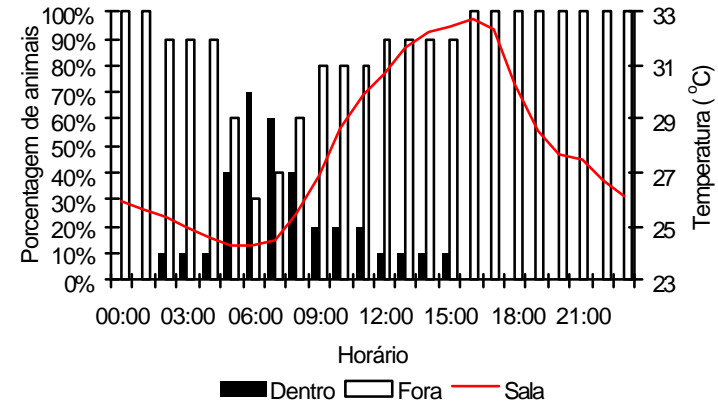

(a)

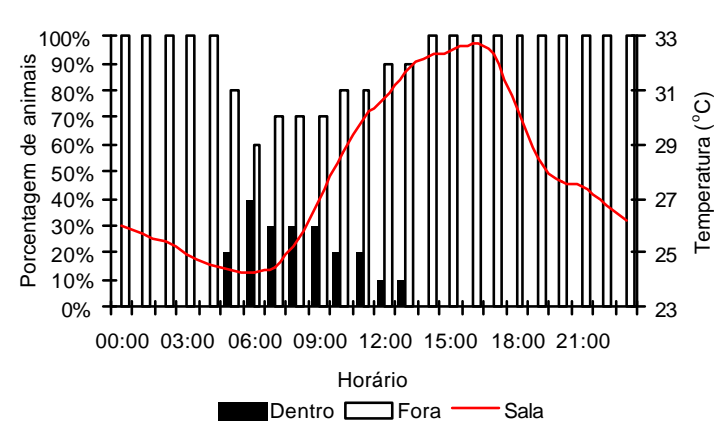

(c)

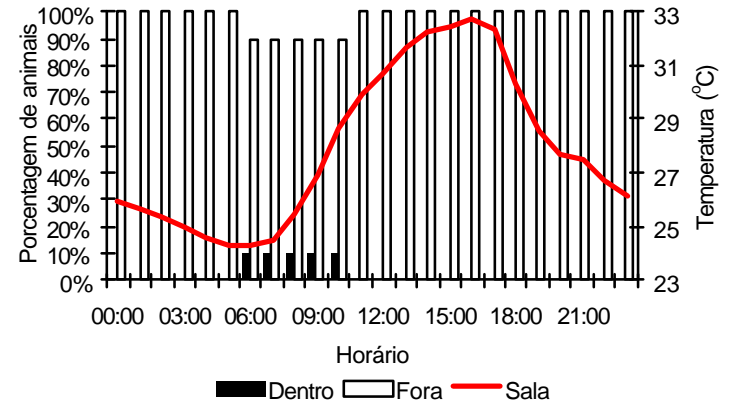

(b)

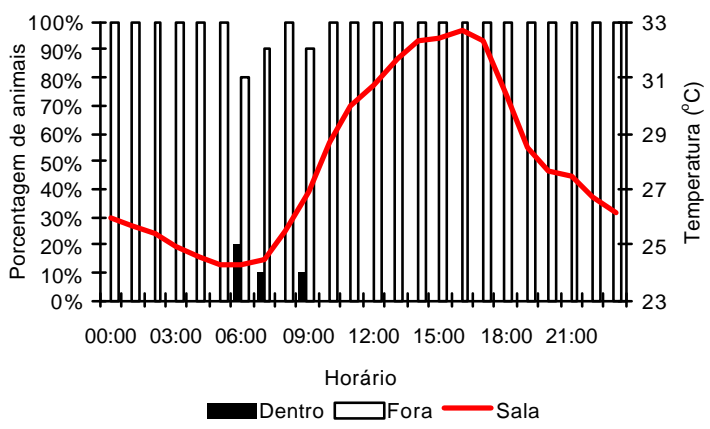

(d)

Figura 22 - Avaliação da freqüência de uso do abrigo escamoteador equipado com piso térmico (a); lâmpada incandescente (b); resistência elétrica (c); lâmpada de infravermelho (d) e a variação da temperatura no interior da sala da maternidade para o dia avaliado (29/03/02).

A avaliação da freqüência de uso pelos leitões nos abrigos escamoteadores foi equacionada por meio de análise de regressão, ajustada para a porcentagem de animais no interior do abrigo, em função da temperatura na sala da maternidade $\left({ }^{\circ} \mathrm{C}\right)$,

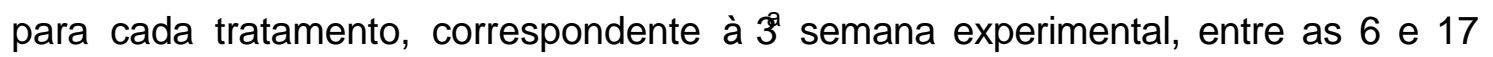
horas, sendo apresentadas na Tabela 8. 
Tabela 8. Equações de regressão ajustadas para porcentagem de animais no abrigo, em função da temperatura da sala da maternidade, durante a etapa de verão, correspondente à $3^{\mathrm{a}}$ semana, para os tratamentos adotados.

\begin{tabular}{lcc}
\hline Tratamentos & Equações ajustadas & $R^{2}$ \\
\hline Piso térmico & $y=-0,0642 x+2,1087$ & $0,8562^{*}$ \\
Lâmpada incandescente & $y=-0,0144 x+0,4642$ & $0,8308^{*}$ \\
Resistência elétrica & $y=-0,0427 x+1,4103$ & $0,9284^{*}$ \\
Lâmpada de infravermelho & $y=-0,0149 x+0,4695$ & $0,5534^{\star *}$ \\
\hline
\end{tabular}

*Significativo a $1 \%$ de probabilidade

${ }^{*}$ Significativo a $5 \%$ de probabilidade

Observando-se as equações, verifica-se que o tratamento piso térmico é aquele que melhor representa a condição térmica ambiental mais adequada para os leitões, em função do seu comportamento, seguido do tratamento resistência elétrica.

Os tratamentos lâmpada incandescente e lâmpada de infravermelho apresentaram condições inadequadas, quando se verificou o comportamento dos leitões, ou seja, apresentaram baixa freqüência de acesso.

\subsubsection{Tempo de permanência dos leitões no interior dos abrigos escamoteadores, na etapa de verão}

Com relação à análise do comportamento dos leitões por meio do monitoramento, pelas microcâmeras, verifica-se que o acesso dos animais e o tempo de permanência nos abrigos equipados com os diferentes sistemas de aquecimento, foram influenciados pelas condições ambientais na sala da maternidade e no interior dos abrigos, que na maioria dos casos, estavam acima da necessidade dos animais. O escamoteador equipado com piso térmico foi o mais visitado, e aquele em que os leitões permaneceram por mais tempo, visto que o sistema promovia temperaturas adequadas aos animais, entre 30 e $32^{\circ} \mathrm{C}$.

$\mathrm{Na}$ Tabela 9, é apresentada a porcentagem de permanência do tempo total (24 horas), no decorrer de cada dia crítico analisado, em que pelo menos 1 leitão se 
encontrava no interior do abrigo.

Deve-se considerar que justamente no verão, devido às altas temperaturas tanto da sala como dos escamoteadores, o tempo de permanência e a freqüência de acesso aos abrigos foram reduzidos.

Tabela 9. Porcentagem de permanência do tempo total (24 horas) no decorrer de cada dia crítico analisado de, pelo menos 1 leitão, no interior do abrigo escamoteador para os diferentes sistemas de aquecimento na etapa de verão.

\begin{tabular}{|c|c|c|c|c|c|c|c|c|c|c|}
\hline & & & \multicolumn{8}{|c|}{ Porcentagem (\%) de permanência do tempo total } \\
\hline & & & \multicolumn{2}{|c|}{ Piso térmico } & \multicolumn{2}{|c|}{$\begin{array}{c}\text { Lâmpada } \\
\text { incandescente }\end{array}$} & \multicolumn{2}{|c|}{$\begin{array}{c}\text { Resistência } \\
\text { elétrica }\end{array}$} & \multicolumn{2}{|c|}{$\begin{array}{l}\text { Lâmpada de } \\
\text { infravermelho }\end{array}$} \\
\hline Dias & $\begin{array}{l}\mathrm{Tm} \\
\left({ }^{\circ} \mathrm{C}\right)\end{array}$ & $\begin{array}{c}\mathrm{H} \\
(\mathrm{kJ} / \mathrm{kg})\end{array}$ & Dentro & Fora & Dentro & Fora & Dentro & Fora & Dentro & Fora \\
\hline $18 / 03$ & 34,3 & 107,5 & 52 & 48 & 4 & 96 & 0 & 100 & 4 & 96 \\
\hline 24/03 & 29,2 & 76,0 & 35 & 65 & 0 & 100 & 26 & 74 & 9 & 91 \\
\hline 29/03 & 27,9 & 76,7 & 61 & 39 & 22 & 78 & 39 & 61 & 13 & 87 \\
\hline \multicolumn{3}{|c|}{ Valores médios } & 49 & 51 & 9 & 91 & 22 & 78 & 9 & 91 \\
\hline
\end{tabular}

De acordo com os resultados apresentados na Tabela 9, verifica-se que para os 3 dias críticos estudados, os valores médios de permanência dos animais dentro dos abrigos foi maior no tratamento piso térmico, resistência elétrica, lâmpada incandescente e lâmpada de infravermelho respectivamente. Nota-se que em 49\% do tempo os animais permaneceram dentro do abrigo com piso térmico, $22 \%$ no abrigo com resistência elétrica e $9 \%$ nos demais. Esses resultados confirmam mais uma vez a eficiência térmica do piso e a resposta do comportamento dos animais com relação, tanto àfreqüência de acesso como ao tempo de permanência dos leitões no abrigo.

Considerando-se 0 período em que os sistemas de aquecimento permaneceram acionados das 20 æ̀s 7 horas (Figuras 23 a, 23 b, 23 c, 23 d). $O$ piso térmico apresentou uma maior freqüência de acesso e tempo de permanência dos leitões no escamoteador, o que pode justificar que o mesmo proporcionou melhores 
condições de conforto aos animais. Por se tratar de um fluxo de calor condutivo, e mais eficiente às trocas de calor, quando o animal deita no piso, ele ganha calor, até que o equilíbrio do processo seja atingido, de 30 a $32^{\circ} \mathrm{C}$, faixa de aquecimento do piso.

Durante esse período quando se analisa o piso térmico, verifica-se que há uma maior procura dos leitões, pois em 54\% das 11 horas (20 æ̀ 7 horas), em que 0 piso ficou aquecendo, constatou-se a presença de pelo menos 1 leitão no interior do abrigo (Figura 23 a).

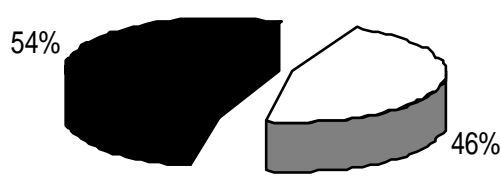

Dentro aFora

(a)

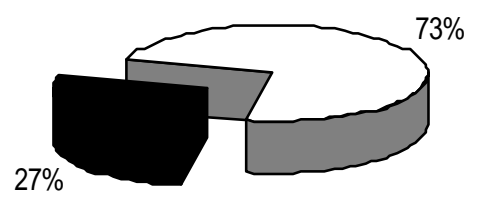

Dentro $\square$ Fora

(c)

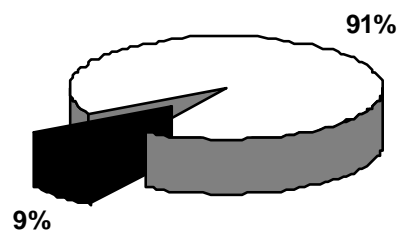

Dentro $\square$ Fora

(b)

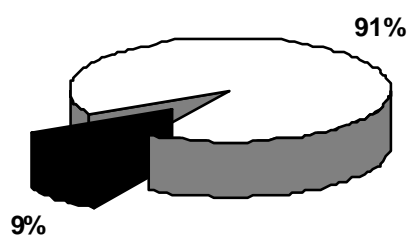

Dentro $\square$ Fora

(d)

Figura 23 - Porcentagem do tempo de permanência dos leitões no abrigo escamoteador equipado com piso térmico (a), lâmpada incandescente (b), resistência elétrica (c) e lâmpada de infravermelho (d) com o sistema de aquecimento acionado, durante 11 horas, para os dias críticos na etapa de verão.

Para o abrigo equipado com lâmpada incandescente, $9 \%$ do tempo em que o 
sistema de aquecimento permaneceu acionado, verificou-se a presença de pelo menos 1 leitão no interior do escamoteador. (Figura 23 b).

Com relação aos dados referentes ao abrigo equipado com resistência elétrica, observa-se que, durante o período em que o sistema de aquecimento permaneceu acionado, cerca de $27 \%$ do tempo, verificou-se presença de leitões no interior do escamoteador (Figura $23 \mathrm{c}$ ).

O abrigo com lâmpada de infravermelho também apresentou um baixo tempo de permanência, quando comparado com o piso térmico e resistência elétrica, ou seja, 9\% do tempo em que permaneceu acionado (Figura $23 \mathrm{~d}$ ). Esse fato é evidenciado pela alta temperatura no interior do escamoteador em relação àtemperatura de conforto dos leitões (32 a $\left.28^{\circ} \mathrm{C}\right)$. Nesse abrigo a variação da temperatura para o horário mais quente e mais frio conseqüentemente foi $34^{\circ} \mathrm{C}$ e $43^{\circ} \mathrm{C}$, respectivamente.

\subsubsection{Avaliação zootécnica dos animais}

\subsubsection{Ganho de peso diário}

Com relação ao ganho de peso dos leitões, não se verificou influência direta dos tratamentos no GPD (kg/dia). Observa-se na Figura 24, que o tratamento lâmpada incandescente não atingiu o índice recomendado para animais nascidos œm peso médio de 1,8 kg, para os demais tratamentos avaliados, todos superaram o valor desejado, ou seja, os tratamentos piso térmico, resistência elétrica e lâmpada incandescente alcançaram um ganho de peso diário acima de 0,240 kg/dia, para um desmame aos 19 dias, com um peso médio de 5,9 kg (Moraes et al., 1998).

Diante desses resultados, nota-se que os tratamentos piso térmico, resistência elétrica e lâmpada incandescente apresentaram valores de 20,4\%, 40,4\% e $5,4 \%$ superiores ao recomendado. Para o tratamento lâmpada incandescente, observase um GPD (kg/dia) de 6,66\% inferior ao limite mínimo exigido. 


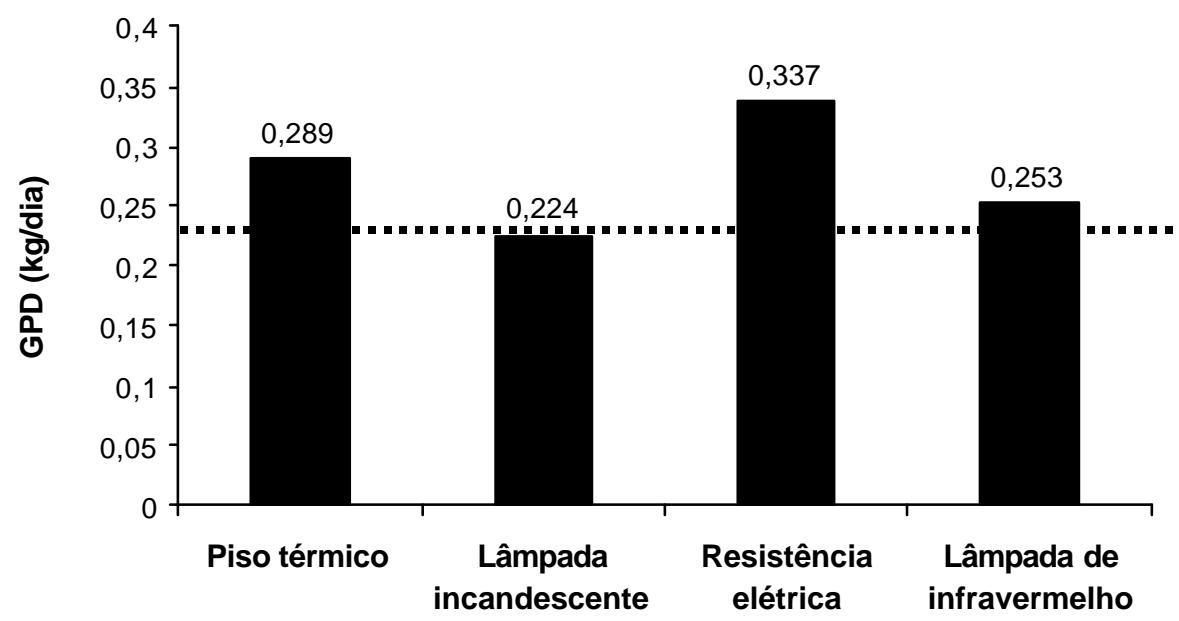

Figura 24 - Ganho de peso (kg/dia), dos leitões submetidos aos diferentes sistemas de aquecimento na etapa de verão.

\subsubsection{Mortalidade}

Não se contabilizou nenhum óbito entre os leitões que compunham os abrigos com os respectivos tratamentos estudados, apesar de que a média da mortalidade registrada na sala da maternidade foi de aproximadamente $5 \%$, ficando dentro do padrão recomendado, especialmente se relacionado ao alto número de leitões, nascidos por parto (média de 11,9), indicando o bom desempenho dos leitões do ponto de vista sanitário.

\subsubsection{Avaliação técnica-econômica dos sistemas de aquecimento}

O consumo de energia dos diferentes sistemas de aquecimento podem ser verificados na Figura 25. Observa-se que o piso térmico apresentou maior consumo, cerca de $20 \%$ superior à lâmpada incandescente comum, 24\% superior à resistência elétrica e 5\% superior ao consumo apresentado pela lâmpada infravermelho. $O$ tratamento mais econômico com relação ao consumo de energia elétrica $(\mathrm{kWh})$ foi a resistência elétrica. Porém, para a região e o período analisado não se recomenda o 
uso de aquecimento nos abrigos escamoteadores, sendo que a condição interna da sala de maternidade estava dentro da faixa de conforto dos leitões. É possível obter o condicionamento ambiental ideal para os leitões lactentes, no sistema preconizado (escamoteador + fonte de aquecimento controlado por termostato), com as fontes de aquecimento de menor potência de funcionamento, proporcionando maior economia de energia elétrica, de acordo com Perdomo et al. (1987).

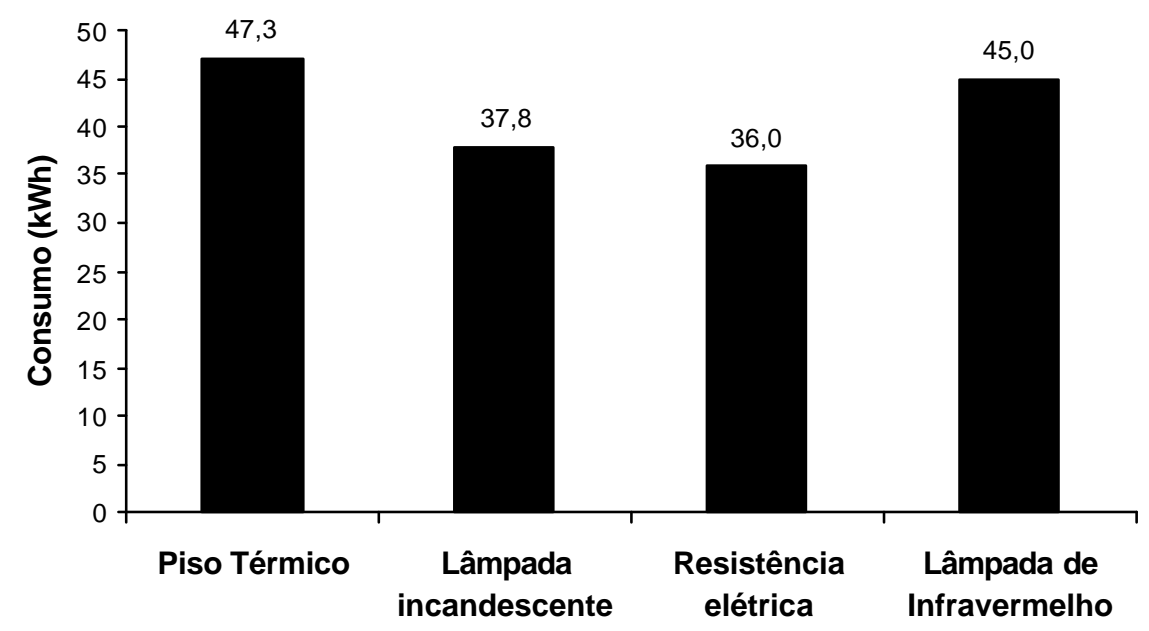

Figura 25 - Consumo de energia elétrica $(k W h)$ dos diferentes sistemas de aquecimento, durante a etapa de verão.

$\mathrm{Na}$ Tabela 10, verifica-se o custo envolvido, em relação ao consumo de energia elétrica dos sistemas de aquecimento estudados, considerando-se tarifa cobrada pela concessionária de $R \$ 0,138270 / \mathrm{kWh}$, para zona rural (CPFL $-5 / 11 / 02)$. 
Tabela 10. Valor total $(R \$)$, pago pelo consumo de energia elétrica $(k W h)$, dos diferentes sistemas de aquecimento avaliados.

\begin{tabular}{ccccc}
\hline & \multicolumn{4}{c}{ Tratamentos } \\
\hline Piso térmico & $\begin{array}{c}\text { Lâmpada } \\
\text { incandescente }\end{array}$ & $\begin{array}{c}\text { Resistência } \\
\text { elétrica }\end{array}$ & $\begin{array}{c}\text { Lâmpada de } \\
\text { infravermelho }\end{array}$ \\
\hline Consumo $(\mathrm{kWh})$ & 47,3 & 37,8 & 36 & 45 \\
Custo $(\mathrm{R} \$)$ & 6,54 & 5,23 & 4,98 & 6,22 \\
\hline
\end{tabular}

Em função dos resultados apresentados na Tabela 10, apesar de não ser recomendado o sistema de aquecimento no escamoteador para o período de verão, nota-se que a resistência elétrica apresentou o menor custo em relação à lâmpada incandescente, lâmpada de infravermelho e piso térmico respectivamente.

\subsection{Análise de dados no inverno}

\subsubsection{Análise das variáveis ambientais e a eficiência térmica dos sistemas de aquecimento para leitões}

\subsubsection{Análise geral}

Para os dados referentes à temperatura na sala da maternidade e no abrigo meteorológico (ambiente externo), foram ajustadas equações, utilizando-se análise de regressão, envolvendo valores médios horários da temperatura externa em função da temperatura na sala da maternidade. As retas de ajuste 1:1 apresentaram uma tendência de variação linear, apresentando valor de $R^{2}(0,3849)$, significativo a $1 \%$ de probabilidade pelo teste $F$, verificando-se valores médios de temperatura, de aproximadamente $31,4 \%$ superiores na sala da maternidade (Figura 26). Essa variação foi justamente observada pelo fato das baixas temperaturas externas, considerando-se que nessa situação o manejo das cortinas era realizado de forma a isolar o meio interno do externo, verificando-se maior controle das flutuações térmicas e, conseqüentemente, uma temperatura maior. O correto manejo das cortinas laterais 
permitia o maior controle no interior da instalação, evitando as altas variações da amplitude térmica, apresentando valor médio da ordem de $3^{\circ} \mathrm{C}$.

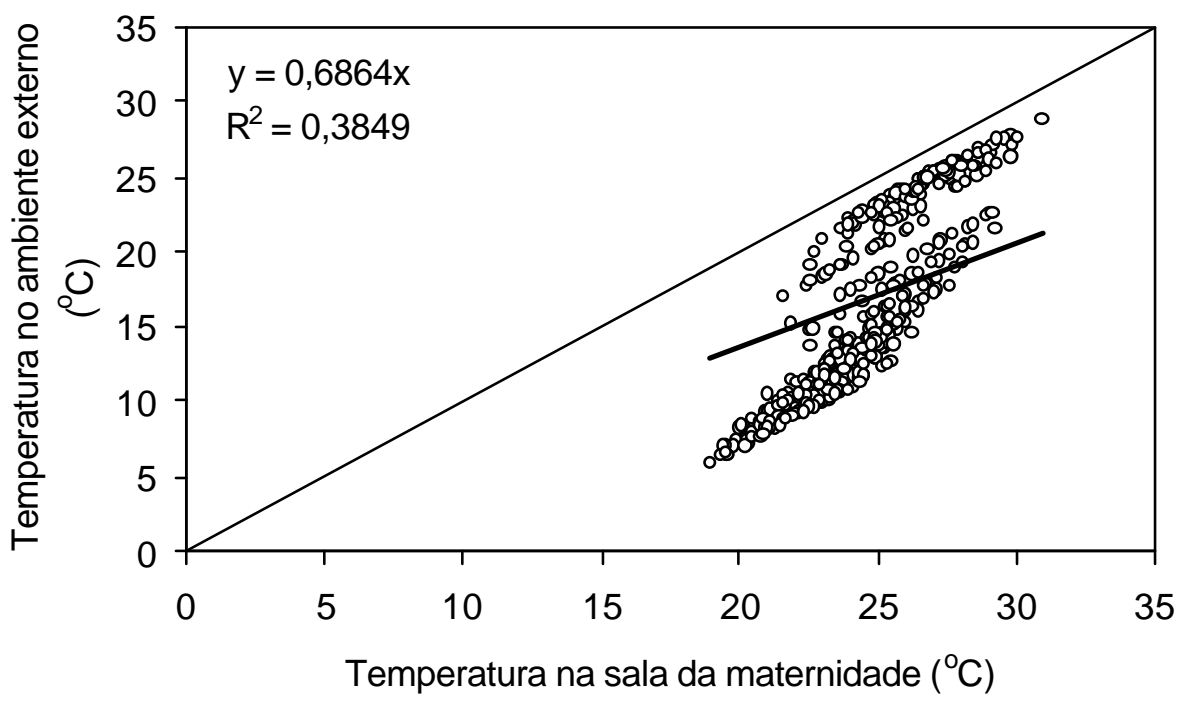

Figura 26 - Representação da correlação entre temperatura na sala da maternidade e no abrigo meteorológico (ambiente externo), na etapa de inverno, envolvendo todos os dados coletados.

A comparação entre tratamentos, apresentados na Tabela 11, são os resultados médios diários das variáveis resposta dos microambientes estudados, abrigos escamoteadores e seus respectivos sistemas de aquecimento. Verificou-se que todos os tratamentos apresentaram diferenças significativas para temperatura de bulbo seco (Ts), temperatura de globo negro (Tg) e umidade relativa (UR).

A temperatura de bulbo seco apresentou uma variação significativa entre os 4 tratamentos estudados. Por meio de valores médios pode-se verificar que o ambiente com piso térmico apresentou uma menor temperatura no microclima gerado, seguido da lâmpada incandescente, resistência elétrica e lâmpada de infravermelho, respectivamente. De uma forma geral, pode-se dizer que, para zona de conforto térmico para os leitões na fase da maternidade, os 3 primeiros tratamentos são recomendados, porém, deve-se lembrar que esses dados são valores médios diários. 
Tabela 11. Valores médios das variáveis ambientais observadas durante a permanência dos leitões na maternidade, durante a etapa de inverno.

\begin{tabular}{lccc}
\hline Fase de inverno & $\operatorname{Ts}\left({ }^{\circ} \mathrm{C}\right)$ & $\operatorname{Tg}\left({ }^{\circ} \mathrm{C}\right)$ & UR $(\%)$ \\
\hline Piso térmico & $28,7 \mathrm{~d}$ & $28,9 \mathrm{c}$ & $60,5 \mathrm{a}$ \\
Lâmpada incandescente & $32,2 \mathrm{c}$ & $32,8 \mathrm{~b}$ & $48,9 \mathrm{~b}$ \\
Resistência elétrica & $32,9 \mathrm{~b}$ & $32,9 \mathrm{~b}$ & $50,6 \mathrm{c}$ \\
Lâmpada de infravermelho & $40,4 \mathrm{a}$ & $41,8 \mathrm{a}$ & $31,7 \mathrm{~d}$ \\
\hline
\end{tabular}

Valores médios com letras diferentes, na mesma coluna, diferem estatisticamente pelo Teste de Tukey, $P<0,01$.

A Figura 27 mostra a influência do efeito dos diferentes sistemas de aquecimento na temperatura interna dos abrigos escamoteadores. Nessas condições, verifica-se que o aquecimento proporcionado aos leitões, pela lâmpada incandescente e resistência elétrica, foi o que mais se aproximou da faixa de conforto térmico dos animais, 32 a $28^{\circ} \mathrm{C}$ (Silva, 1999). O tratamento, piso térmico esteve abaixo da condição recomendada, principalmente na $1^{\mathrm{a}}$ semana de vida dos animais.

Com relação àlâmpada de infravermelho, os dados referentes àtemperatura, no interior do abrigo, esteve, em média, sempre acima da condição ideal, durante toda fase experimental, ultrapassando o valor da temperatura crítica superior (TCS) de 38 a $33^{\circ} \mathrm{C}$ (Mount, 1968; Curtis, 1983).

Deve-se verificar que essa tendência diferiu dos dados de verão, principalmente com relação à variação da temperatura externa que teve seus valores bem inferiores nesse período. Em função disso, a eficiência dos tratamentos foi diferenciada, quando comparados com períodos mais quentes. 


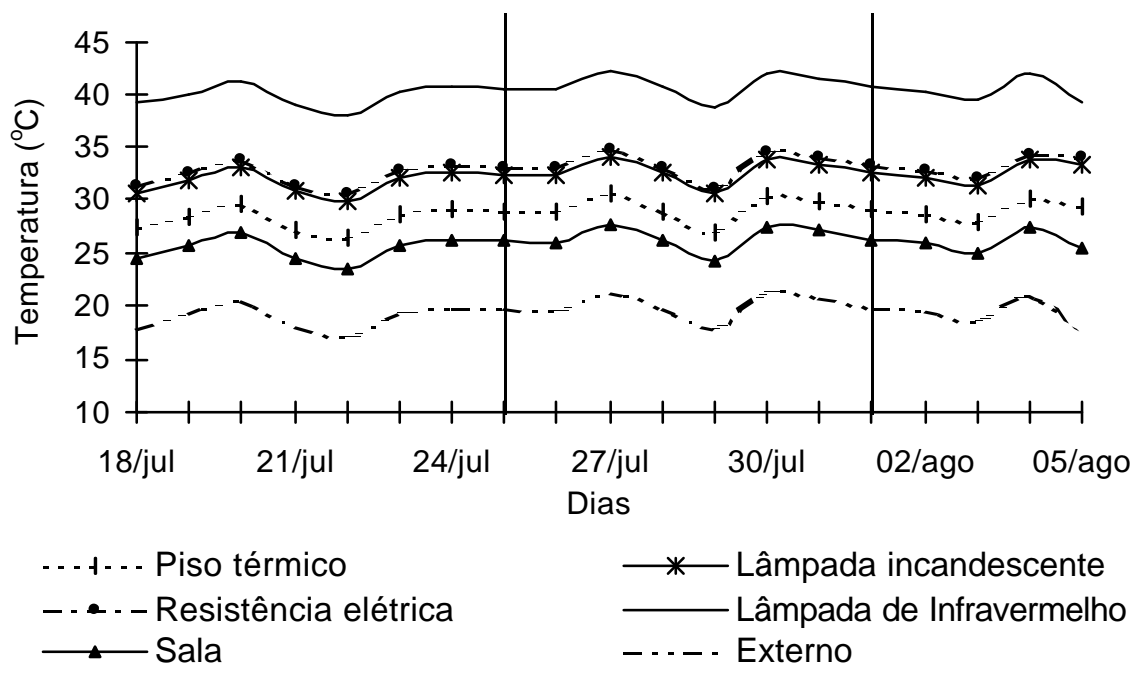

Figura 27 - Variação da temperatura média diária na etapa de inverno nos diferentes tratamentos na sala da maternidade e no abrigo meteorológico (ambiente externo).

Com a intenção de validar as informações obtidas, pela variação da temperatura média diária, nos tratamentos avaliados, observa-se na Figura 28, a variação das temperaturas mínimas diárias. Esses resultados demonstram que a condição de conforto, na $\uparrow^{a}$ e $2^{a}$ semana de vida dos animais, é atendida pelos tratamentos, lâmpada incandescente e resistência elétrica. Para o tratamento piso térmico, a disponibilidade de energia térmica, proporcionada pela fonte de aquecimento, não foi suficiente para as duas semanas iniciais, contemplando as exigências dos animais, apenas na $3^{\mathrm{a}}$ semana.

O tratamento equipado com lâmpada de infravermelho, apresentou, praticamente, a mesma resposta, mostrando-se sempre acima da condição adequada, atingindo valores de $\operatorname{TCS}$ de $38^{\circ} \mathrm{C}$. 


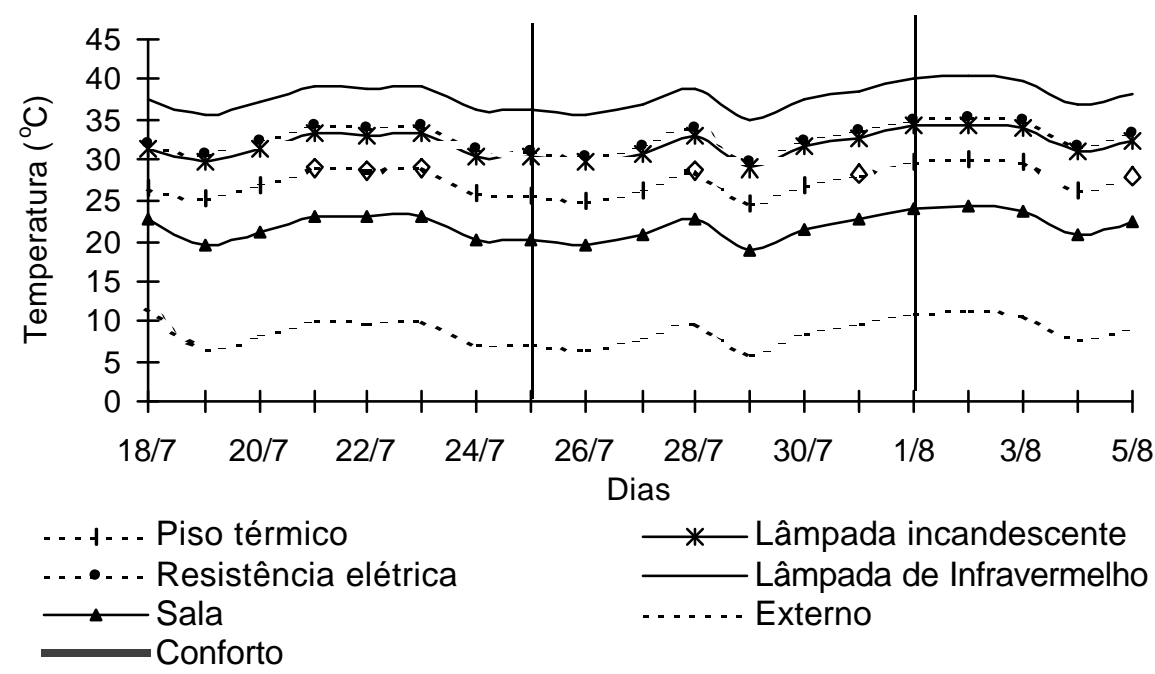

Figura 28 - Variação da temperatura mínima diária na etapa de inverno nos diferentes tratamentos, sala da maternidade e no abrigo meteorológico (ambiente externo).

Os sistemas de aquecimento mais adequados, mesmo para os dias selecionados, dias de menor entalpia, foram lâmpada incandescente e resistência elétrica (Figura 29). Para os outros tratamentos, a temperatura se apresentou acima (lâmpada de infravermelho), e abaixo (piso térmico), das condições de conforto térmico dos leitões, 32 a $28^{\circ} \mathrm{C}$. 


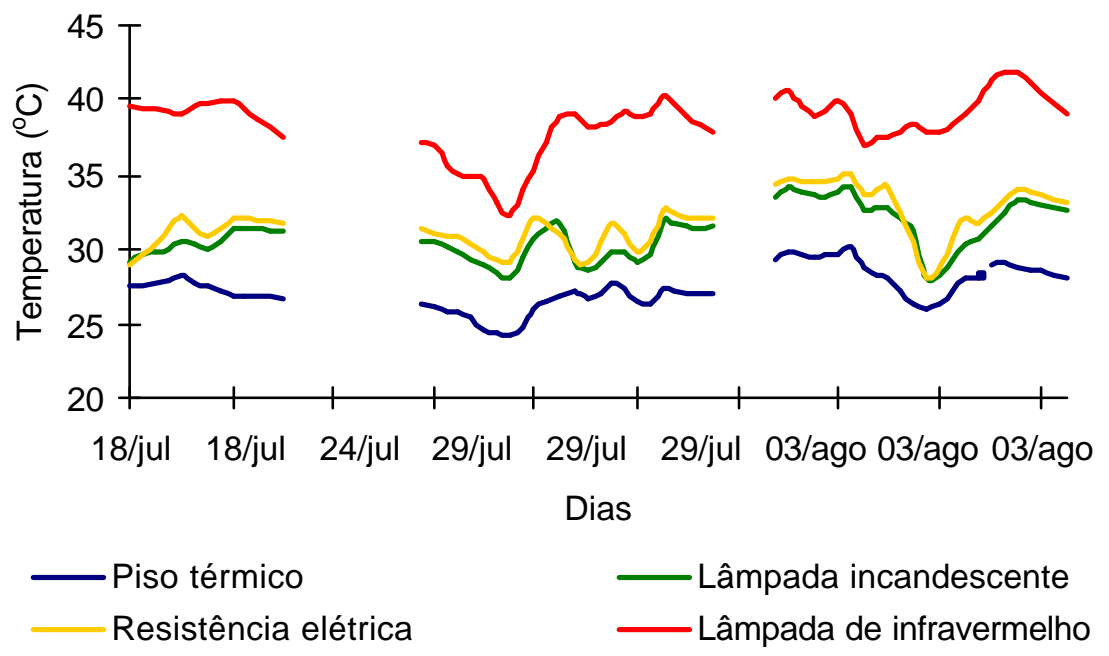

Figura 29 - Variação da temperatura para os dias de menor entalpia na etapa de inverno nos diferentes tratamentos avaliados.

Com relação aos dados referentes à temperatura de globo negro, os valores registrados para os diferentes sistemas de aquecimento estudados, apresentaram o mesmo comportamento da Ts, devido à pequena variação apresentada entre as respectivas variáveis ambientais.

A variação da umidade relativa do ar, no interior dos escamoteadores, apresentou diferenças significativas, principalmente no abrigo equipado com lâmpada de infravermelho, que além de promover altas temperaturas no interior do abrigo, reduziu significativamente a umidade relativa no seu interior, pois, o volume de ar se contrai e/ou expande com a variação da temperatura. Essa variação de volume impõe um limite àquantidade de vapor d'água que pode ser retida pelo volume de ar, ou seja, quanto maior a temperatura, maior a quantidade máxima saturante de vapor d'água. Dessa forma, verificam-se baixos valores de UR para essa situação.

Com relação ao tratamento com piso térmico, a energia térmica radiante, proveniente do piso, não foi suficiente para promover redução da UR, nos níveis verificados nos demais tratamentos, apresentando valor mais próximo do ideal, entre 60 e 70\% (Nääs, 1989; Silva, 1999) (Figura 30). 


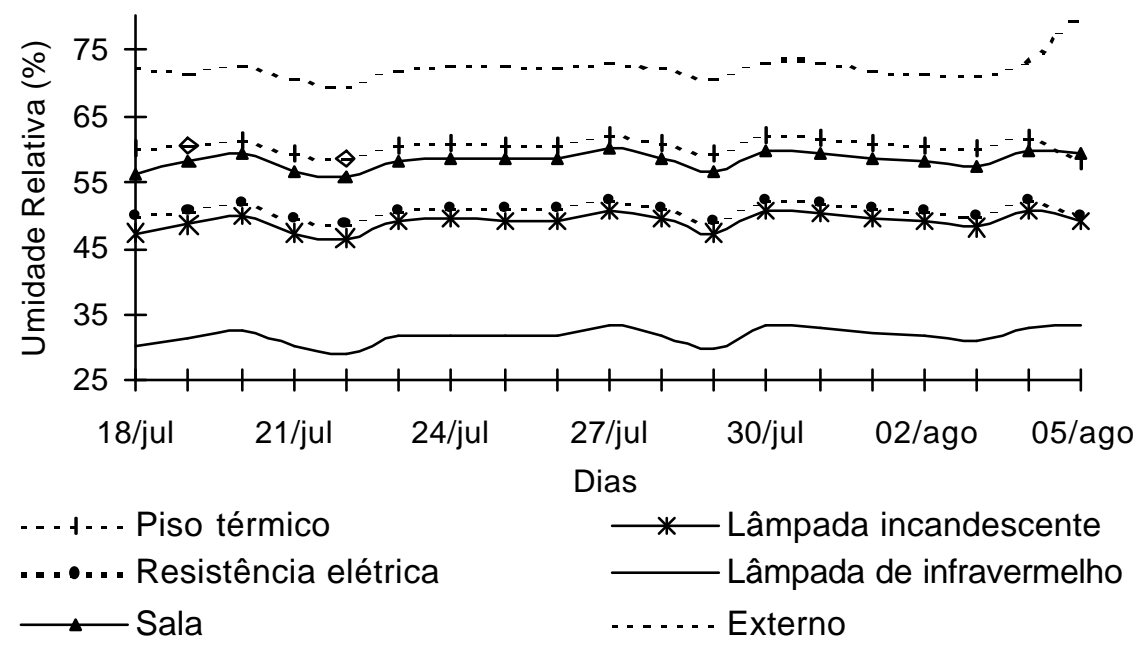

Figura 30 - Variação da umidade relativa média diária na etapa de inverno nos diferentes tratamentos na sala da maternidade e no abrigo meteorológico (ambiente externo).

\subsubsection{2 Índices de conforto térmico}

As médias dos índices de ITGU, CTR e H, correspondentes à segunda etapa da pesquisa (inverno), em função dos tratamentos adotados, estão apresentadas na Tabela 12.

Tabela 12. Valores médios dos índices de conforto, ITGU, CTR e H, observados na segunda etapa (inverno), durante a permanência dos leitões na maternidade.

\begin{tabular}{lccc}
\hline \multicolumn{1}{c}{ Fase de inverno } & ITGU & CTR & H \\
\hline Piso térmico & $77,5 \mathrm{~b}$ & $473,0 \mathrm{~d}$ & $68,9 \mathrm{~d}$ \\
Lâmpada incandescente & $81,3 \mathrm{a}$ & $493,2 \mathrm{c}$ & $72,1 \mathrm{c}$ \\
Resistência elétrica & $82,3 \mathrm{a}$ & $496,5 \mathrm{~b}$ & $75,9 \mathrm{~b}$ \\
Lâmpada de infravermelho & $81,1 \mathrm{a}$ & $554,6 \mathrm{a}$ & $81,1 \mathrm{a}$ \\
\hline
\end{tabular}

Valores médios com letras diferentes, na mesma coluna, diferem estatisticamente pelo pelo Teste de Tukey, $\mathrm{P}<0,01$. 
O índice de temperatura de globo e umidade (ITGU) apresentou valores médios para resistência elétrica, lâmpada incandescente e lâmpada de infravermelho, que não diferiram estatisticamente. O menor valor médio de ITGU foi verificado para o tratamento piso térmico, diferindo-se estatisticamente, quando comparado com os demais (Tabela 12).

Com relação ao ITGU, considerando-se o dia de menor entalpia, na $1^{\mathrm{a}}, 2^{\mathrm{a}}$ e $3^{\mathrm{a}}$ semana avaliadas, verifica-se na Figura 31, que os abrigos equipados com lâmpada incandescente e resistência elétrica, foram aqueles que apresentaram valores mais próximos do ideal, 82 a 84 (Necoechea, 1986), para os 3 dias críticos, dias de menor entalpia, estudados. Os abrigos equipados com lâmpada de infravermelho e piso térmico apresentaram valores acima e abaixo do recomendado, respectivamente.

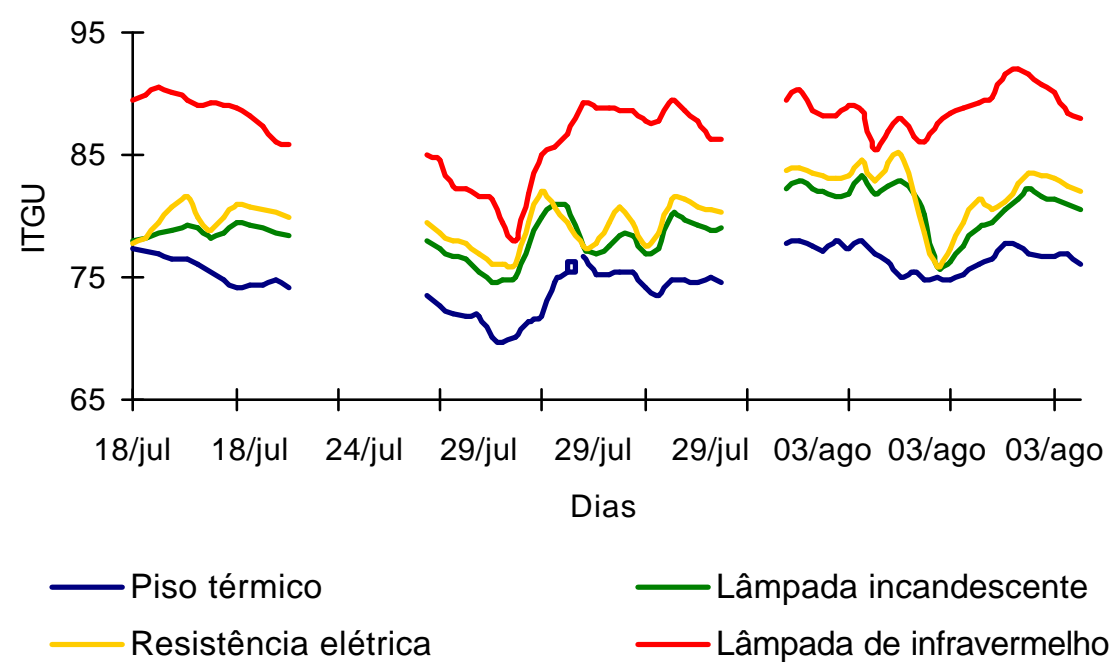

Figura 31 - Variação do índice de temperatura de globo e umidade para os dias de menor entalpia na etapa de inverno nos diferentes tratamentos avaliados.

Observando-se os valores médios da CTR, verifica-se diferenças significativas para lâmpada de infravermelho, resistência elétrica, lâmpada incandescente e piso térmico, respectivamente. O maior valor de CTR foi observado para o tratamento lâmpada de infravermelho, verificando-se valores superiores àenergia radiante média recomendada, de aproximadamente $450 \mathrm{~W} / \mathrm{m}^{2}$ (Baêta \& Souza, 1997). A CTR apresentada pelo piso térmico foi aquela que mais se aproximou da condição 
recomendada, $473 \mathrm{~W} / \mathrm{m}^{2}$. Além da fonte de aquecimento, atribui-se os altos valores de CTR no interior dos abrigos, por se tratar de um ambiente pequeno, vedado, com pequena velocidade de ar $(0,03 \mathrm{~m} / \mathrm{s})$. Deve-se considerar que a CTR é influenciada pelo efeito convectivo juntamente com a temperatura média radiante. Pelos dados apresentados, nota-se que todos excederam a condição recomendada para os animais.

Comparando-se a CTR de cada tratamento, para os dias considerados críticos, verifica-se que o tratamento piso térmico foi aquele que apresentou valores mais próximos do recomendado, permitindo um fluxo de calor de aproximadamente 450 $\mathrm{W} / \mathrm{m}^{2}$ (Baêta e Souza, 1997). Para os outro sistemas de aquecimento, todos apresentam valores superiores àquele considerado suficiente para manutenção da condição de conforto dos leitões (Figura 32).

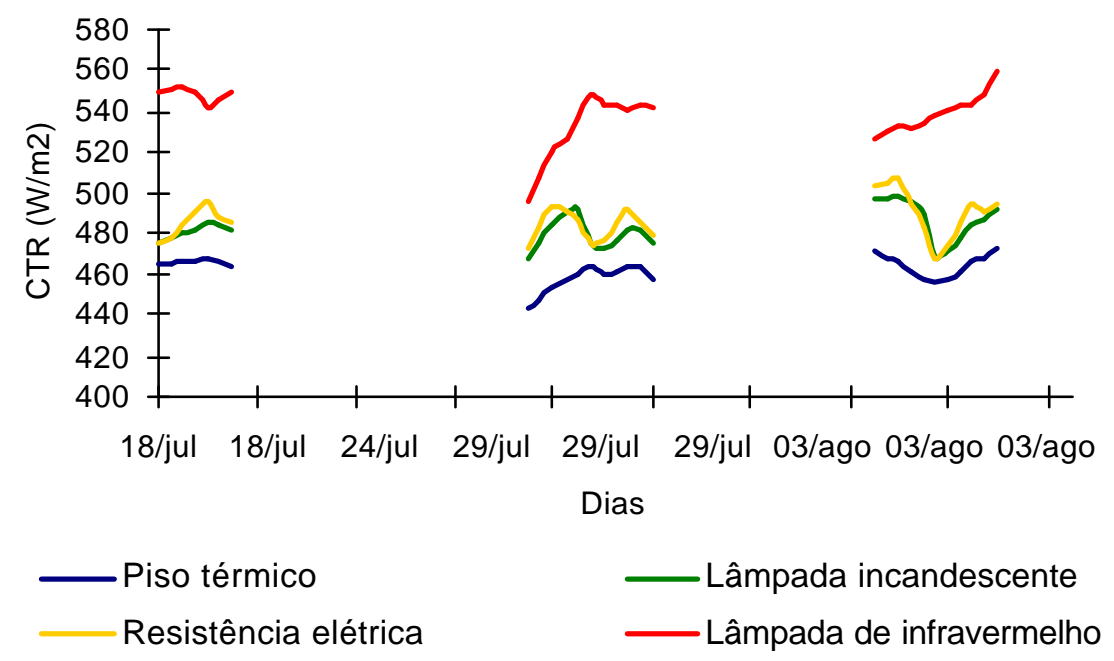

Figura 32 - Variação da carga térmica radiante (CTR), para os dias de menor entalpia, na etapa de inverno, nos diferentes tratamentos avaliados.

Os valores médios da entalpia $(\mathrm{H})$ apresentam resultados que apontam diferenças estatísticas entre todos os tratamentos. O maior valor verificado foi para o abrigo equipado com lâmpada de infravermelho, resistência elétrica, lâmpada incandescente e piso térmico, respectivamente, expressando a quantidade de energia interna da parcela de ar, nos microambientes avaliados, em relação à soma de suas 
componentes, de uma mistura de ar seco e vapor d'água, levando-se em consideração a Ts $\left({ }^{\circ} \mathrm{C}\right)$ e a razão de mistura (kg de vapor d'água/kg de ar seco).

Pode-se verificar na Figura 33, que a variação entálpica nos tratamentos adotados, para $1^{\text {a }}$ semana experimental, não atingiu o valor ideal de 90,2 kJ/kg ar seco, em nenhum dos tratamentos avaliados, sendo que o sistema de aquecimento, que mais se aproximou do valor recomendado, foi a lâmpada de infravermelho. Para a $2^{a}$ semana, o tratamento mais eficiente foi a resistência elétrica, que apresentou valores mais próximos de $81,6 \mathrm{~kJ} / \mathrm{kg}$ ar seco. Na última semana, os tratamentos lâmpada incandescente e resistência elétrica foram aqueles que melhor se ajustaram àcondição ideal, de $73,8 \mathrm{~kJ} / \mathrm{kg}$ ar seco, o piso térmico, esteve sempre abaixo da condição entálpica necessária ao conforto dos leitões.

As aproximações dos valores de entalpia, recomendada para os animais, foram calculadas com base nas condições de conforto dos animais, 32,30 e $28^{\circ} \mathrm{C}$, e umidade relativa de $70 \%$, citadas por Silva (1999), para a primeira, segunda e terceira semanas de vida dos leitões, respectivamente.

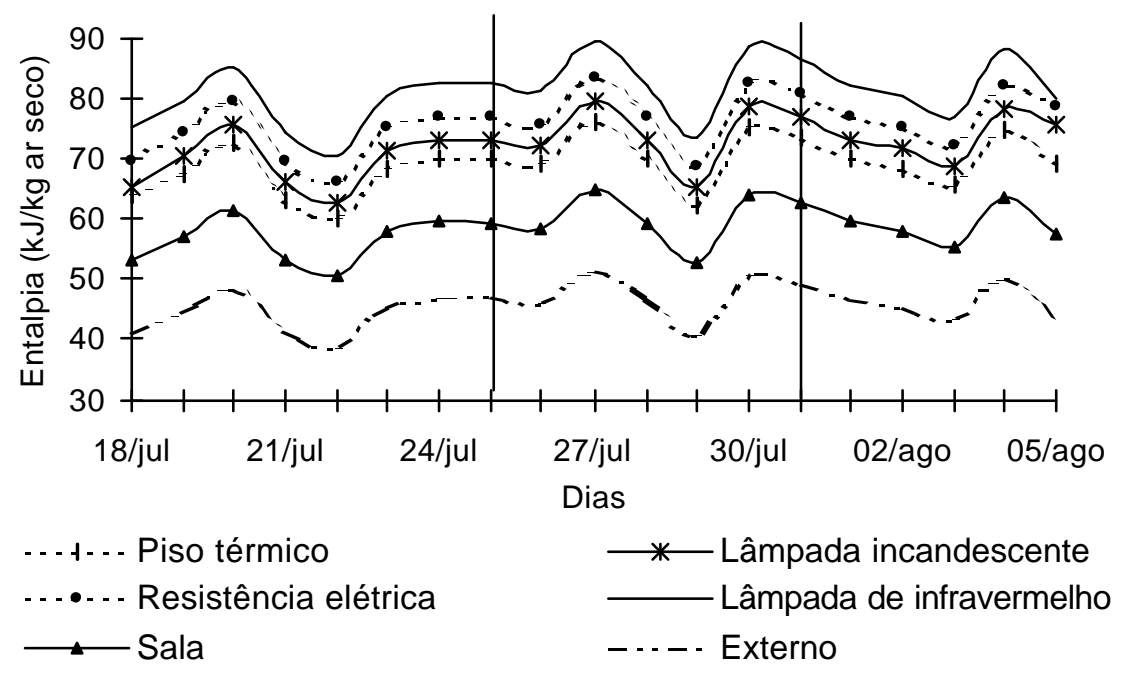

Figura 33 - Variação da entalpia média diária na etapa de inverno nos diferentes tratamentos na sala da maternidade e no abrigo meteorológico (ambiente externo). 
Para certificar-se das informações citadas acima, procurou-se representar as variações mínimas de entalpia verificadas nesta fase, como se pode observar na Figura 34. Consideram-se as condições mínimas de entalpia o cálculo dessa grandeza psicrométrica, utilizando a temperatura mínima diária.

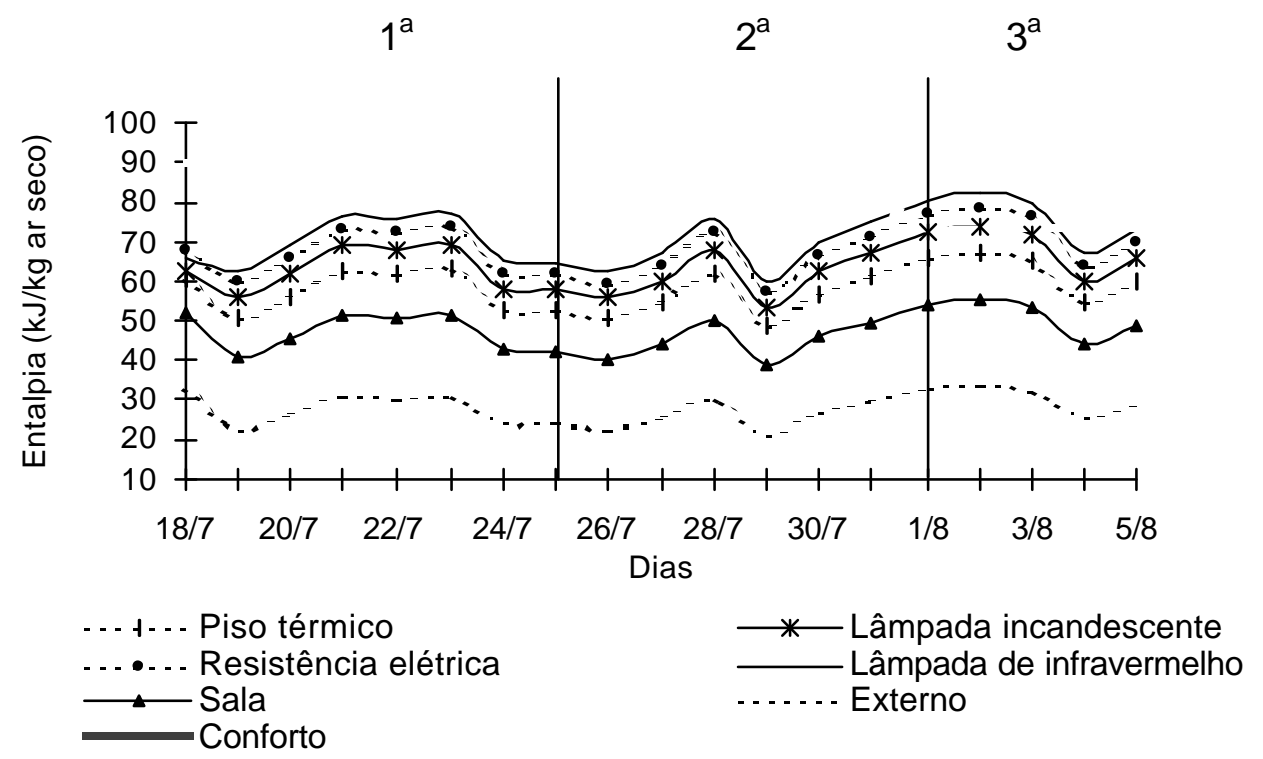

Figura 34 - Variação da entalpia mínima diária na etapa de inverno nos diferentes tratamentos na sala da maternidade e no abrigo meteorológico (ambiente externo).

Considerando-se a quantidade de calor existente na massa de ar seco dentro de cada abrigo escamoteador, pode-se dizer, pelos dados apresentados na Figura 34, que nenhum dos tratamentos estudados foi eficiente no acondicionamento dos animais, durante as duas primeiras semanas críticas de vida dos leitões, porém, para a $3^{\mathrm{a}}$ semana, os sistemas de aquecimento, lâmpada incandescente, resistência elétrica e lâmpada de infravermelho, atenderam efetivamente a condição de conforto dos animais. 


\subsubsection{Análise do comportamento dos leitões no inverno}

\subsubsection{Freqüência de acesso dos leitões ao abrigo escamoteador}

Deve-se considerar que, para análise da freqüência de acesso dos leitões ao abrigo escamoteador, analisaram-se os 3 dias considerados críticos do período. Dessa forma, baseando-se no tempo de permanência dos animais dentro dos abrigos observados na Tabela 14, selecionou-se o dia 03/08/02 para análise individual e horária da freqüência de acesso.

A comparação entre a freqüência de acesso e a variação da temperatura, na sala da maternidade, foi realizada para o dia em que se observou o maior número de acessos dos leitões ao abrigo representado pela porcentagem de animais no interior do mesmo, considerando que durante todo o período de inverno o sistema de aquecimento permanecia acionado com as cortinas fechadas, o que diferiu do manejo no verão, quando o sistema era acionado æ̀ 20 horas e desligado æ̀s 7 horas.

De acordo com as Figuras 35 (a), (b), (c) e (d), verificou-se que a freqüência de acesso aos abrigos está diretamente relacionada com a variação de temperatura. Em todos os casos citados anteriormente, observa-se que, quando houve redução da temperatura na sala da maternidade, mínima observada æ̀s 6 horas, verificou-se a maior freqüência de acesso aos abrigos.

Os dados apontam que, no tratamento piso térmico, houve uma maior freqüência de acesso dos leitões ao longo do dia, praticamente em todos os horários, variando com a temperatura na sala (Figura 35 a).

Analisando-se a Figura 35 (b), percebe-se que a freqüência de acesso foi pontual, ou seja, em intervalos entre 5 e 11 horas, retomando a utilização novamente, das 19 æ̀ 23 horas, em que ocorreu o início da redução da temperatura.

Essa tendência pode ser verificada nos demais tratamentos, em que se pode observar que, para o dia crítico, a predominância de freqüência de acesso aos abrigos pelos leitões foi piso térmico, resistência elétrica, lâmpada de infravermelho e lâmpada incandescente, respectivamente. 


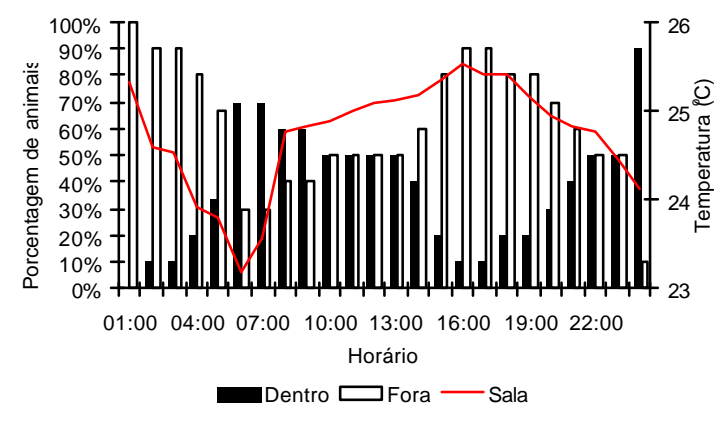

(a)

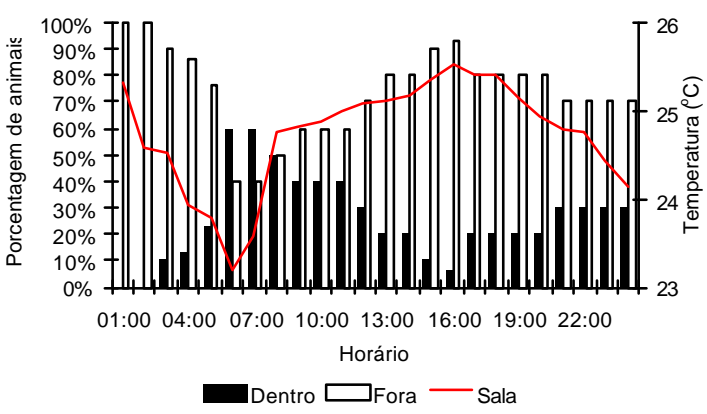

(c)

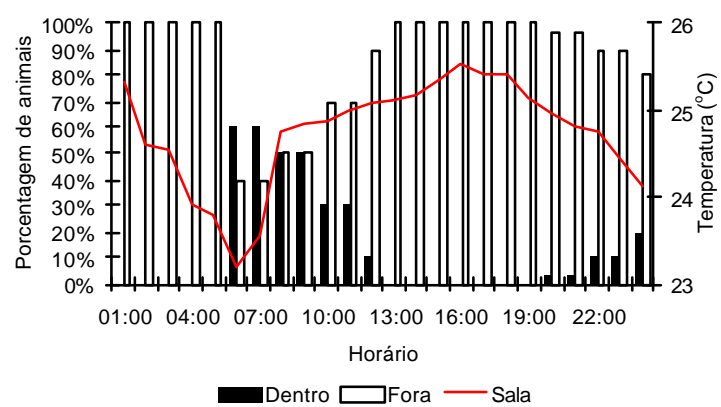

(b)

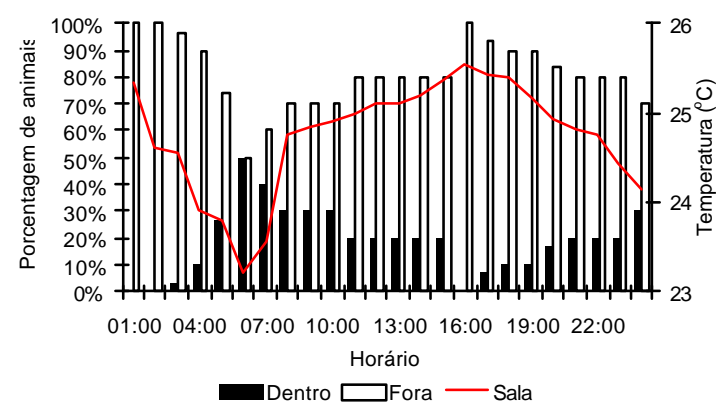

(d)

Figura 35 - Avaliação da freqüência de acesso ao abrigo escamoteador equipado com piso térmico (a), lâmpada incandescente (b); resistência elétrica (c); lâmpada de infravermelho (d) e a variação da temperatura na sala da maternidade na etapa de inverno, para o dia avaliado (03/08/02).

As equações de regressão ajustadas para a porcentagem de animais no interior dos abrigos, em função da temperatura na sala da maternidade, para cada tratamento, correspondente à ${ }^{\mathrm{a}}$ semana experimental, são apresentadas na Tabela 13. A Tabela 13 está relacionada com o dia 03/08/02, considerado crítico do período e de maior freqüência de acesso, no decorrer de 24 horas. 
Tabela 13. Equações de regressão ajustadas para porcentagem de animais no abrigo, em função da temperatura da sala da maternidade, correspondente à $3^{a}$ semana da etapa de inverno, para os tratamentos adotados.

\begin{tabular}{lcc}
\hline \multicolumn{1}{c}{ Tratamentos } & Equações ajustadas & $R^{2}$ \\
\hline Piso térmico & $\mathrm{y}=-0,1342 x+3,5299$ & $0,9554^{*}$ \\
Lâmpada incandescente & $\mathrm{y}=-0,1411 \mathrm{x}+3,5405$ & $0,9124^{*}$ \\
Resistência elétrica & $\mathrm{y}=-0,1043 \mathrm{x}+2,6624$ & $0,9055^{*}$ \\
Lâmpada de infravermelho & $\mathrm{y}=-0,1178 \mathrm{x}+3,0462$ & $0,969^{*}$ \\
\hline
\end{tabular}

*Significativo a $1 \%$ de probabilidade

Por meio das equações, verifica-se que o tratamento piso térmico é aquele que melhor representa a condição térmica ambiental mais adequada para os leitões.

Para os demais tratamentos, lâmpada incandescente, resistência elétrica e lâmpada de infravermelho apresentaram as mesmas respostas em relação ao comportamento dos leitões.

\subsubsection{Tempo de permanência dos leitões no interior dos abrigos escamoteadores}

Com relação à análise do comportamento dos leitões, por meio do monitoramento, pelas microcâmeras e pela identificação eletrônica, verifica-se que a utilização dos sistemas de aquecimento foi influenciada pelas condições ambientais na sala da maternidade e no interior dos abrigos, que, na maioria dos casos, atendia a necessidade dos animais. $O$ escamoteador equipado com piso térmico foi o mais visitado, e aquele onde os leitões permaneceram por mais tempo, visto que o sistema promovia temperaturas adequadas aos animais, entre 30 e $32^{\circ} \mathrm{C}$, como se pode observar na Tabela 14. Para a resistência elétrica e lâmpada de infravermelho, verificase que o tempo de permanência dos animais no interior do abrigo foi alto, uma vez que o sistema de aquecimento atendia suficientemente as necessidades dos animais. Com relação à lâmpada incandescente, observa-se menor tempo de permanência dos 
animais no interior do abrigo, na $3^{\mathrm{a}}$ semana avaliada, fato que se pode atribuir àidade dos animais nesse tratamento, que tinham uma exigência térmica menor.

Tabela 14. Porcentagem de permanência do tempo total no decorrer ce cada dia analisado de pelo menos 1 leitão no interior do abrigo escamoteador para os diferentes sistemas de aquecimento na etapa de inverno.

\begin{tabular}{|c|c|c|c|c|c|c|c|c|c|c|}
\hline \multirow[b]{3}{*}{ Dias } & \multirow[b]{3}{*}{$\begin{array}{l}\mathrm{Tm} \\
\left({ }^{\circ} \mathrm{C}\right)\end{array}$} & \multirow[b]{3}{*}{$\begin{array}{c}\mathrm{H} \\
(\mathrm{kJ} / \mathrm{kg})\end{array}$} & \multicolumn{8}{|c|}{ Porcentagem (\%) de permanência do tempo total } \\
\hline & & & \multicolumn{2}{|c|}{ Piso térmico } & \multicolumn{2}{|c|}{$\begin{array}{c}\text { Lâmpada } \\
\text { incandescente }\end{array}$} & \multicolumn{2}{|c|}{$\begin{array}{l}\text { Resistência } \\
\text { elétrica }\end{array}$} & \multicolumn{2}{|c|}{$\begin{array}{l}\text { Lâmpada de } \\
\text { infravermelho }\end{array}$} \\
\hline & & & Dentro & Fora & Dentro & Fora & Dentro & Fora & Dentro & Fora \\
\hline $18 / 07$ & 24,5 & 53,1 & 83 & 17 & 74 & 26 & 48 & 52 & 78 & 22 \\
\hline 29/07 & 24,1 & 52,5 & 83 & 17 & 52 & 48 & 65 & 35 & 87 & 13 \\
\hline 03/08 & 25,8 & 55,3 & 100 & 0 & 43 & 57 & 96 & 4 & 87 & 13 \\
\hline \multicolumn{3}{|c|}{ Valores médios } & 89 & 11 & 56 & 44 & 70 & 30 & 84 & 16 \\
\hline
\end{tabular}

Considerando-se que os sistemas de aquecimento permaneceram acionados, durante toda fase de inverno, o piso térmico apresentou uma maior freqüência de uso e tempo de permanência dos animais no escamoteador, o que permite justificar que 0 mesmo proporcionou melhores condições de conforto aos animais. Por se tratar de um fluxo de calor condutivo, são mais eficientes às trocas de calor. Dessa forma, quando o animal deita no piso, ele ganha calor, até que o equilíbrio do processo seja atingido, de 30 a $32^{\circ} \mathrm{C}$, faixa de aquecimento do piso.

Quando se analisa o piso térmico nos abrigos, verifica-se que há uma maior procura, pois em $89 \%$ do tempo (24 horas), constatou-se a presença de pelo menos 1 leitão, no interior do abrigo (Figura 36 a).

O abrigo com lâmpada incandescente foi o que apresentou menor tempo de permanência dos animais no abrigo, apresentando valor da ordem de $56 \%$ do tempo total (24 horas), quando comparado com os demais (Figura 36 b). 


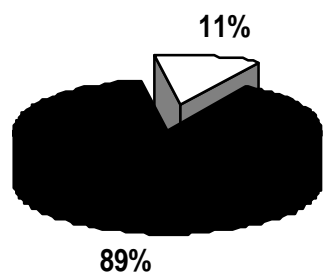

Dentro DFora

(a)

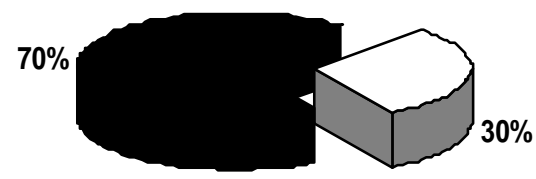

Dentro DFora

(c)

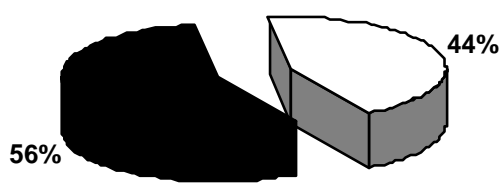

Dentro DFora

(b)

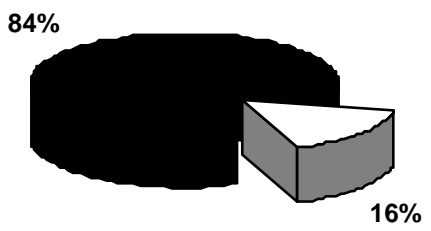

Dentro $\square$ Fora

Figura 36 - Porcentagem média do tempo de permanência dos leitões no abrigo escamoteador equipado com piso térmico (a), lâmpada incandescente (b), resistência elétrica (c) e lâmpada de infravermelho (d), durante æ̀s 24 horas de acionamento do sistema, na etapa de inverno para os dias críticos avaliados.

Com relação aos dados referentes ao abrigo equipado com resistência elétrica, observa-se que, cerca de $70 \%$ do tempo, verificou-se presença de leitões no interior do escamoteador, em virtude da própria condição ambiental proporcionada pela fonte de aquecimento, apresentando valores médios da ordem de 50,6\% de UR, temperatura de $32,9^{\circ} \mathrm{C}$, entalpia de $76 \mathrm{~kJ} / \mathrm{kg}$ de ar seco, conforme os dados apresentados na Tabela 11, proporcionando condições mais próximas da faixa de conforto dos leitões (Figura $36 \mathrm{c}$ ).

No abrigo escamoteador com lâmpada de infravermelho, constatou-se uma permanência dos animais dentro do mesmo de $84 \%$ do tempo (24 horas), como se 
pode observar na Figura 36 d, em função das condições ambientais proporcionadas pela fonte de aquecimento, apresentando valores médios da ordem de $31,7 \%$ de UR, $40,4^{\circ} \mathrm{C}$ de temperatura, entalpia de $81,1 \mathrm{~kJ} / \mathrm{kg}$ ar seco, conforme os dados apresentados na Tabela 11.

\subsubsection{Análise do comportamento dos leitões, em função do uso da geoestatística na avaliação das isotermas do piso nos diferentes sistemas de aquecimento}

A determinação da temperatura no ambiente em que os animais foram expostos é de fundamental importância para o entendimento do comportamento e distribuição dos animais no abrigo escamoteador.

As ferramentas utilizadas nesta pesquisa, permitiram, por meio de microcâmeras de vídeo, identificar o posicionamento de cada animal no microambiente estudado.

Em função dessas informações, associou-se o posicionamento dos animais com o perfil de distribuição da temperatura no piso de cada abrigo estudado. Dessa forma, a análise foi realizada para o dia 03/08/02, crítico do período, considerado mais frio, porém, para os horários de maior e menor temperatura nesse dia, de acordo com os dados apresentados na Tabela 15.

Tabela 15. Valores horários de temperatura no interior da sala da maternidade, para o dia crítico (03/08/02).

\begin{tabular}{cccc}
\hline Horário & Temperatura $\left({ }^{\circ} \mathrm{C}\right)$ & Horário & Temperatura $\left({ }^{\circ} \mathrm{C}\right)$ \\
\hline $\mathbf{8 : 0 0}$ & $\mathbf{2 4 , 7}$ & $15: 00$ & 25,4 \\
$9: 00$ & 24,8 & $\mathbf{1 6 : 0 0}$ & $\mathbf{2 5 , 5}$ \\
$10: 00$ & 24,8 & $17: 00$ & 25,4 \\
$11: 00$ & 25,0 & $18: 00$ & 25,4 \\
$12: 00$ & 25,1 & $19: 00$ & 25,1 \\
$13: 00$ & 25,1 & $20: 00$ & 24,9
\end{tabular}


14:00 25,2

Nas Figuras 37 (a) e 38 (a), são apresentadas as imagens capturadas pela microcâmera, no abrigo equipado com piso térmico, nos horários das 8 e 16 horas, em que se observa a distribuição dos animais no abrigo. Nas Figuras 37 (b) e 38 (b), mostra-se o resultado do comportamento dos animais em função da temperatura do piso, em que se observa as isotermas no abrigo.

De acordo com a Figura 37 (b), observa-se que no horário mais frio do dia (8 horas), a disposição dos animais está localizada na região onde a faixa da temperatura do piso é maior, nesse caso entre 29,7 e $30,7^{\circ} \mathrm{C}$. Da mesma forma, observa-se que no horário em que a temperatura é maior (16 horas), a distribuição dos leitões é diferenciada ao longo dos perfis das isotermas no piso, ou seja, $71 \%$ dos animais presentes no abrigo permaneceram na faixa de temperatura entre 29,6 e $30,6^{\circ} \mathrm{C}$, e $29 \%$ em regiões onde a temperatura do piso era em torno de $28^{\circ} \mathrm{C}$ (Figura $38 \mathrm{~b}$ ).

Esses efeitos podem ser explicados pela eficiência condutiva do piso térmico e pela exigência térmica dos animais. Deve-se considerar que a análise foi realizada na $3^{\mathrm{a}}$ semana de vida dos animais.

Por meio da geoestatística aplicada nesta pesquisa, verifica-se também a eficiência do sistema de aquecimento relacionado com o perfil de distribuição da temperatura ao longo do abrigo escamoteador.

Comparando-se os abrigos com lâmpada incandescente e resistência elétrica, verifica-se que a distribuição da temperatura é reduzida, àmedida que se afasta da fonte de aquecimento (Figuras 39 b, 40 b, 41 b, 42b).

Essa tendência é observada também no piso do abrigo com lâmpada de infravermelho, porém, observa-se que as temperaturas no piso são inferiores à ideais requeridas (Figuras 43b, 44b). Diante disso, sabe-se que o processo convectivo é alterado em função da movimentação do ar no interior do escamoteador, o que pode influenciar na distribuição das isotermas no mesmo.

Nessas condições de estudo, contou-se com uma cama de maravalhas, servindo como isolante térmico do piso, porém, em todos os tratamentos se adotou o mesmo sistema. Pode-se observar que a distribuição da temperatura no abrigo com piso térmico foi mais uniforme, o que confirma os resultados apresentados anteriormente. 
Referindo-se ao perfil de distribuição dos leitões no interior dos abrigos, verifica-se, em geral, que, para todos os tratamentos avaliados, os animais apresentaram a tendência de buscar pontos mais próximos da fonte de calor, ou as faixas de maior temperatura, no horário das 8:00 horas, sendo que para o horário das 16:00 horas, o padrão de distribuição se inverteu, ou seja, os animais buscaram regiões do piso, que apresentavam faixas de menor temperatura e mais distantes da fonte de calor.

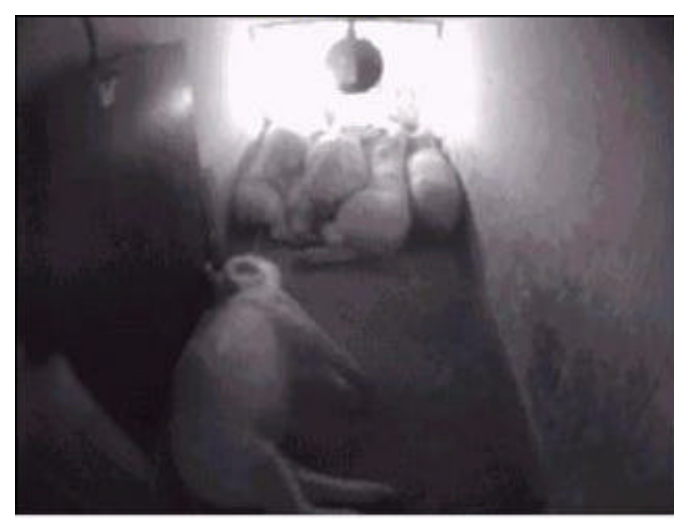

(a)

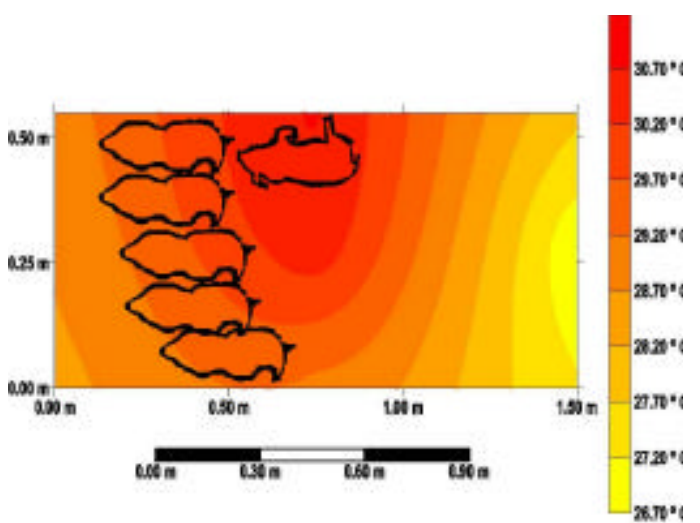

(b)

Figura 37 - Imagem capturada (a) e representação das isotermas (b), representando o perfil de distribuição dos animais, para o abrigo equipado com piso térmico, para æ̀े 8:00 horas na etapa de inverno (03/08/02).

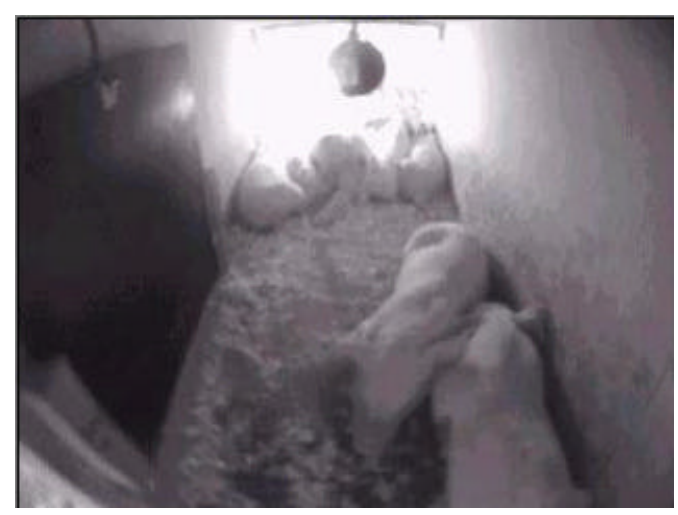

(a)

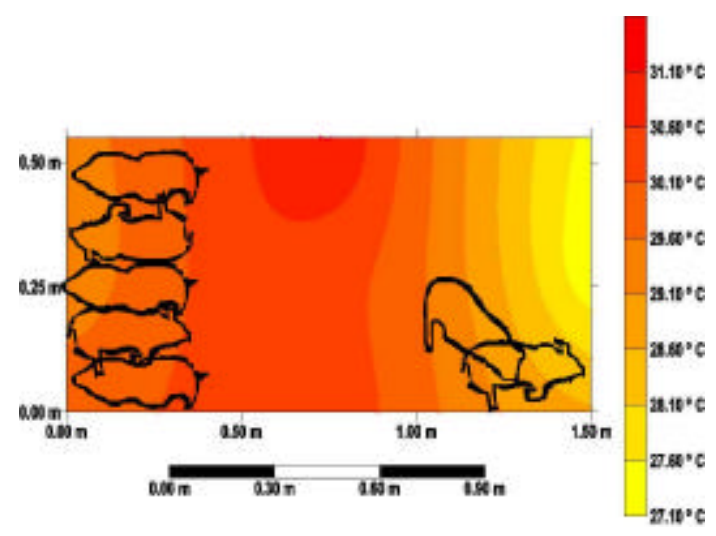

(b)

Figura 38 - Imagem capturada (a) e representação das isotermas (b), representando o perfil de distribuição dos animais, para o abrigo equipado com piso térmico, para æ̇ 16:00 horas na etapa de inverno (03/08/02). 


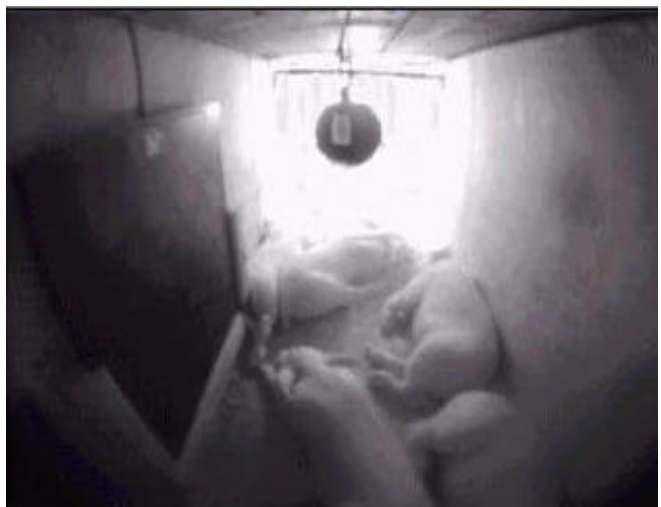

(a)

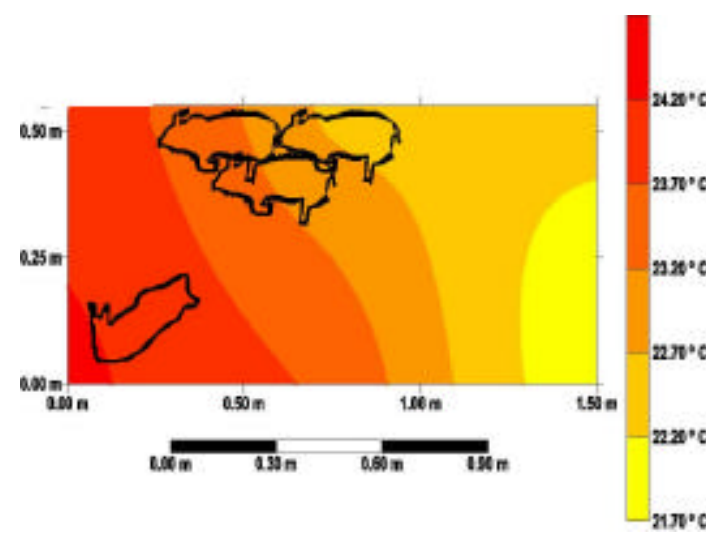

(b)

Figura 39 - Imagem capturada (a) e representação das isotermas (b), representando o perfil de distribuição dos animais, para o abrigo equipado com lâmpada incandescente, para æ̀̀ 8:00 horas na etapa de inverno (03/08/02).

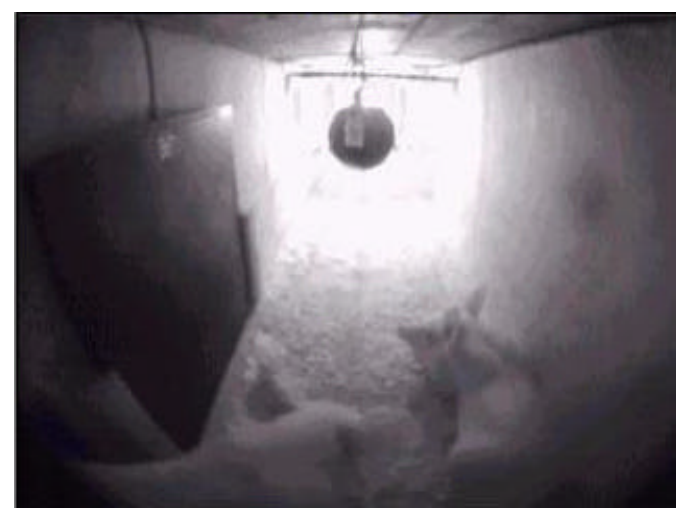

(a)

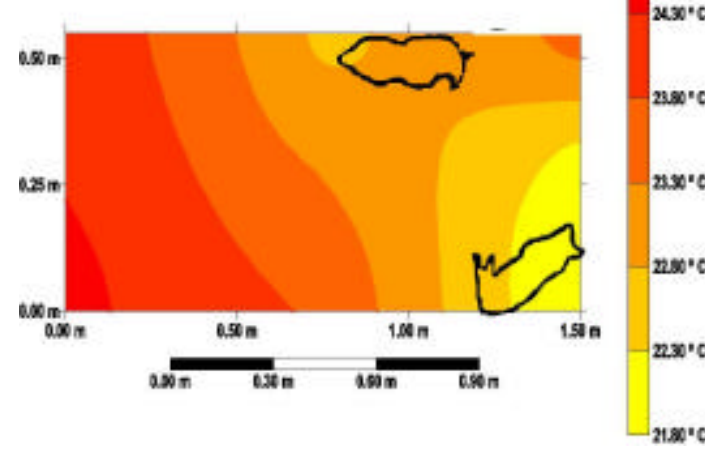

(b)

Figura 40 - Imagem capturada (a) e representação das isotermas (b), representando o perfil de distribuição dos animais, para o abrigo equipado com lâmpada incandescente, para æ̀ 16:00 horas na etapa de inverno (03/08/02). 


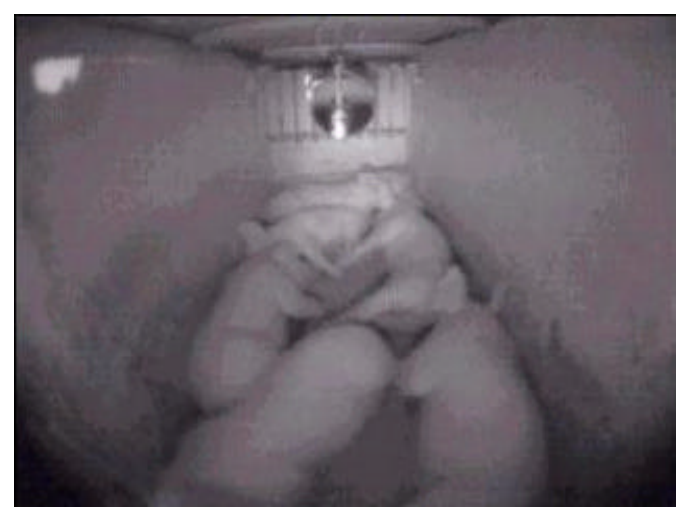

(a)

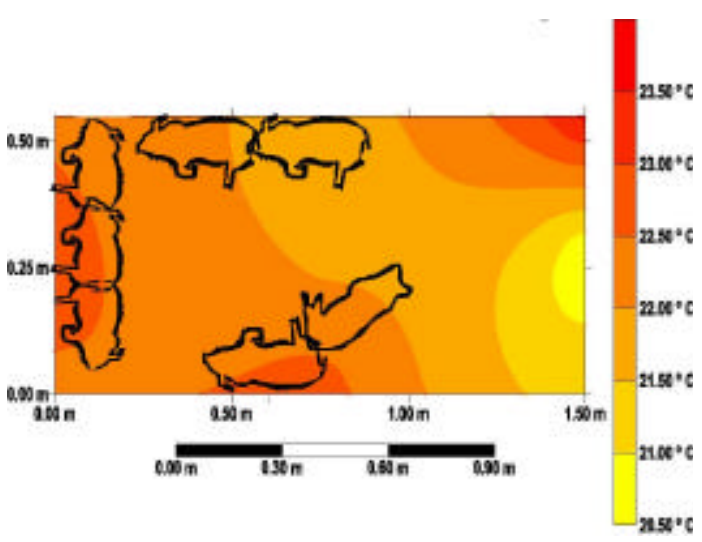

(b)

Figura 41 - Imagem capturada (a) e representação das isotermas (b), representando o perfil de distribuição dos animais, para o abrigo equipado com resistência elétrica, para æ̀ 8:00 horas na etapa de inverno (03/08/02).

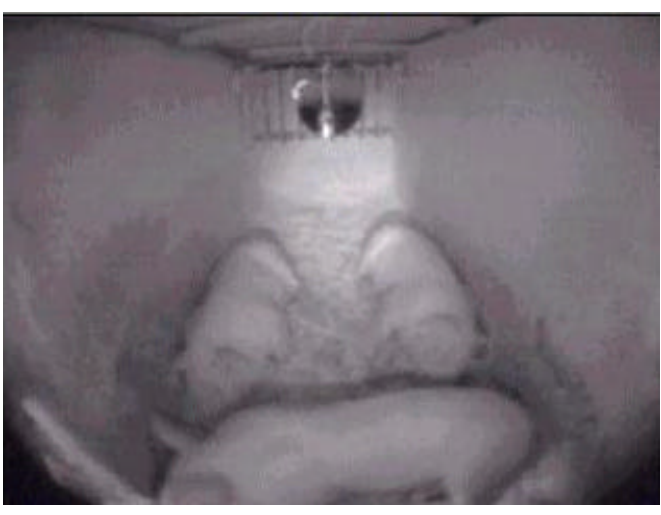

(a)

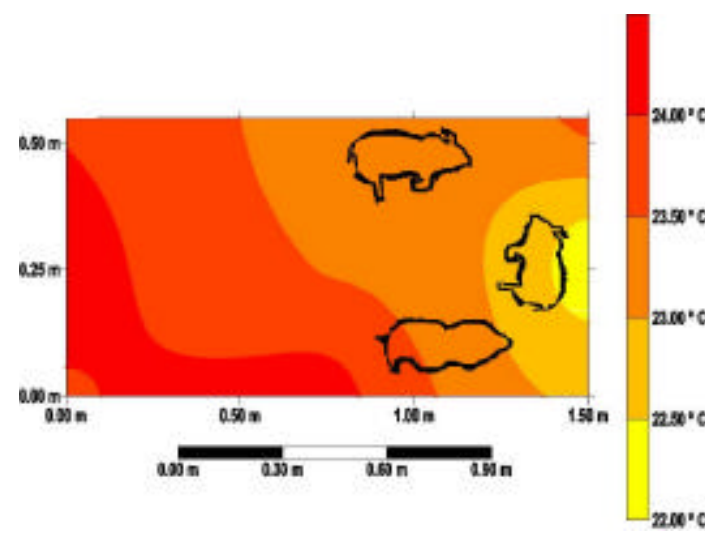

(b)

Figura 42 - Imagem capturada (a) e representação das isotermas (b), representando o perfil de distribuição dos animais, para o abrigo equipado com resistência elétrica, para æ̀s 16:00 horas na etapa de inverno (03/08/02). 


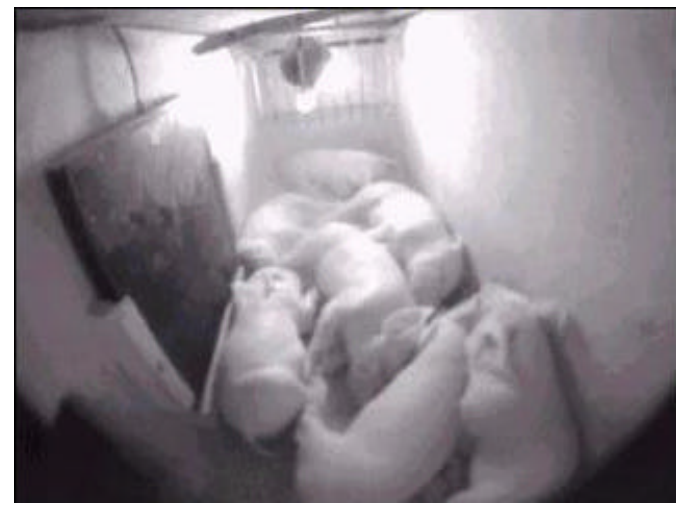

(a)

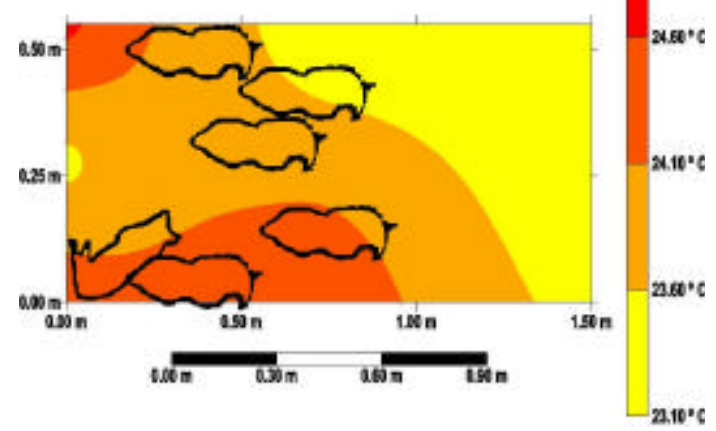

(b)

Figura 43 - Imagem capturada (a) e representação das isotermas (b), representando o perfil de distribuição dos animais, para o abrigo equipado com lâmpada de infravermelho, para æ̀ 8:00 horas na etapa de inverno (03/08/02).

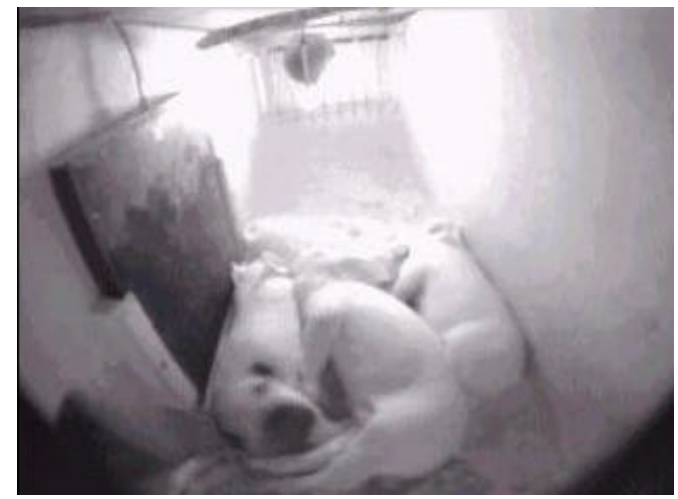

(a)

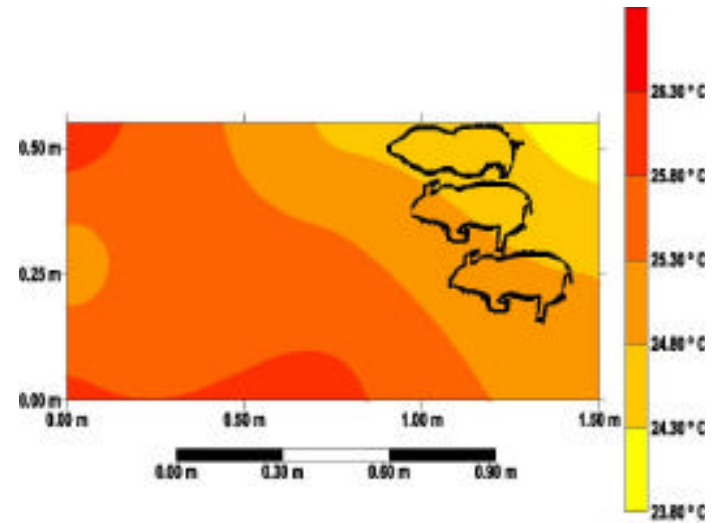

(b)

Figura 44 - Imagem capturada (a) e representação das isotermas (b), representando o perfil de distribuição dos animais, para o abrigo equipado com lâmpada de infravermelho, para æ̀ 16:00 horas na etapa de inverno (03/08/02).

Nesse contexto, a associação das variáveis ambientais estudadas, índices de conforto e avaliação comportamental, confirmam e validam os resultados da geoestatística aplicada no entendimento bioclimático dos leitões. 


\subsubsection{Avaliação Zootécnica}

\subsubsection{Ganho de peso}

Com relação ao ganho de peso dos leitões, observa-se, na Figura 45, que todos os tratamentos avaliados atingiram os índices desejados, ou seja, para todos os sistemas de aquecimento os leitões superaram um ganho de peso diário de 0,240 kg, para leitões nascidos com um peso médio de 1,8 kg e um desmame aos 19 dias, com um peso médio de 6,4 kg (Moraes et al., 1998).

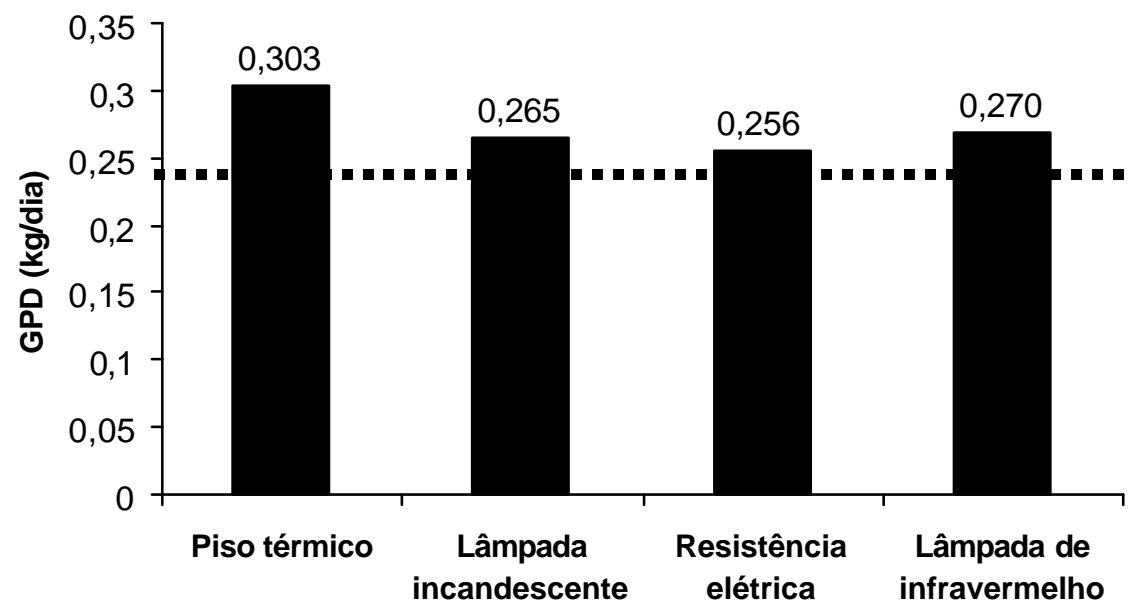

Figura 45 - Ganho de peso (kg/dia) dos leitões submetidos aos diferentes sistemas de aquecimento na etapa de inverno.

O abrigo equipado com piso térmico foi aquele que apresentou os melhores resultados para ganho de peso diário de 0,303 $\mathrm{kg} / \mathrm{dia}$, seguido da lâmpada de infravermelho, lâmpada incandescente e resistência elétrica, verificando-se uma tendência na relação comportamento animal $x$ condicionamento térmico ambiental $x$ desempenho dos leitões. Esses resultados demonstram o que foi discutido anteriormente, ou seja, o bem-estar animal, em função do condicionamento térmico, alterou o GPD (kg/dia) dos animais. 
Ao se comparar com os resultados de verão, verifica-se uma outra tendência, porém sabe-se que a eficiência do sistema de aquecimento para leitões deve ser atingida para o período de inverno.

\subsubsection{Mortalidade}

Não se contabilizou nenhum óbito entre os leitões que utilizaram os abrigos com os respectivos tratamentos estudados, apesar da média registrada na sala da maternidade ser de aproximadamente 5\%, considerando-se dentro de um valor médio aceitável, especialmente se relacionados com o alto número de leitões nascidos por parto (média 11,9).

\subsubsection{Avaliação técnico-econômica dos sistemas de aquecimento}

O consumo de energia dos diferentes sistemas de aquecimento, para a fase de verão e inverno, pode ser verificado na Figura 46. Observa-se que na fase de inverno, o consumo de energia elétrica foi superior, quando comparado com a fase de verão, visto que os sistemas ficaram ligados durante toda fase estudada. Na fase de inverno, o abrigo equipado com piso térmico, apresentou um consumo superior de energia elétrica, verificando-se valores da ordem de, 48, 49 e 34\%, em relação à lâmpada incandescente, resistência elétrica e lâmpada de infravermelho, respectivamente.

Ao se comparar os dois período estudados, evidencia-se que o consumo de energia no inverno foi superior devido ao tempo em que os sistemas de aquecimento permaneceram acionados. 


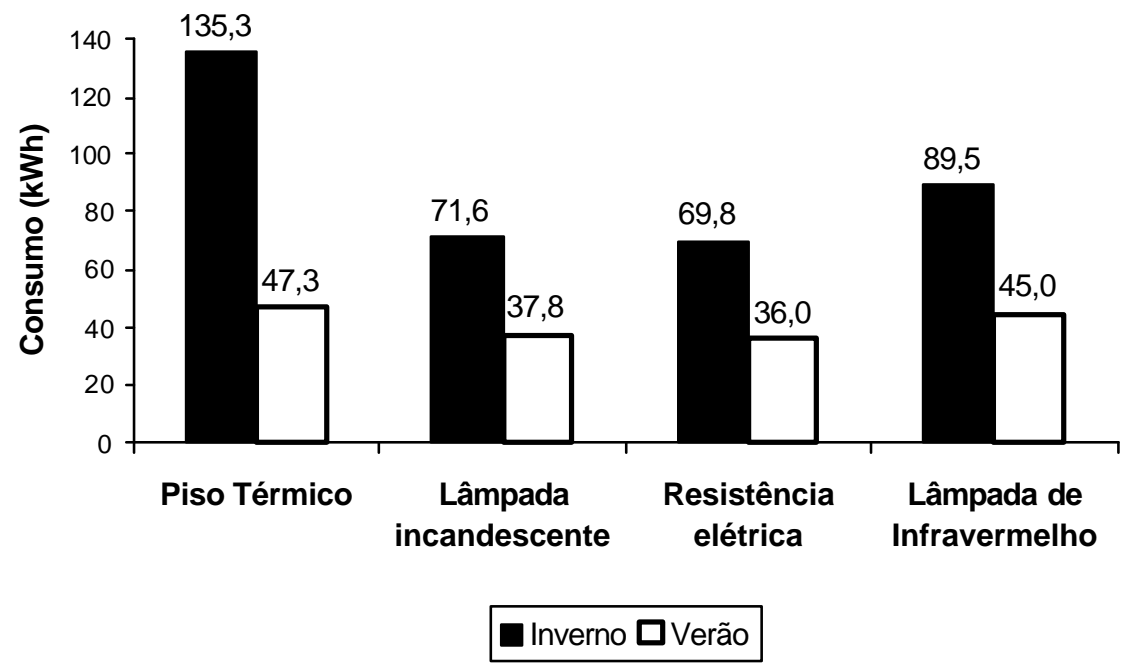

Figura 46 - Consumo de energia elétrica (kWh) dos diferentes sistemas de aquecimento para as etapas de verão e inverno.

$\mathrm{Na}$ Tabela 16, verifica-se o custo envolvido, em relação ao consumo de energia elétrica dos sistemas de aquecimento estudados, para fase de verão e inverno, considerando-se tarifa cobrada pela concessionária de $\mathrm{R} \$ 0,138270 / \mathrm{kWh}$, para zona rural (CPFL - 5/11/02). Para feito de comparação, também são apresentados os valores de rendimento e ganho de peso dos animais em relação aos diferentes sistemas de aquecimento adotados, considerando o $\mathrm{kg}$ do peso vivo de leitões em torno de $R \$ 8,00$, de acordo com a Associação Brasileira de Criadores de Suínos (ABCS), cotação do dia 13/10/2002 (Porkworld, 13/11/02). 
Tabela 16. Valor total $(R \$)$, pago pelo consumo de energia elétrica $(k W h)$, dos diferentes sistemas de aquecimento avaliados e o seu rendimento $(R \$)$, para fase de verão e inverno.

\begin{tabular}{|c|c|c|c|c|c|}
\hline & & \multicolumn{4}{|c|}{ Tratamentos } \\
\hline & & PT & $\mathrm{LI}$ & $\mathrm{RE}$ & LV \\
\hline \multirow[t]{5}{*}{ Verão } & Consumo (kWh) & 47,3 & 37,8 & 36 & 45 \\
\hline & Custo $(\mathrm{R} \$)$ & 6,54 & 5,23 & 4,98 & 6,22 \\
\hline & GPd (kg) & 5,49 & 4,26 & 6,40 & 4,81 \\
\hline & Preço pago $(\mathrm{R} \$)$ & 43,92 & 34,10 & 51,20 & 38,50 \\
\hline & Rendimento $(\mathrm{R} \$)$ & 37,38 & 28,87 & 46,22 & 32,28 \\
\hline \multirow[t]{5}{*}{ Inverno } & Consumo (kWh) & 135,3 & 71,6 & 69,8 & 89,5 \\
\hline & Custo $(\mathrm{R} \$)$ & 18,71 & 9,90 & 9,65 & 12,41 \\
\hline & GPd (kg) & 5,76 & 5,03 & 4,86 & 5,13 \\
\hline & Preço pago $(\mathrm{R} \$)$ & 46,10 & 40,24 & 38,90 & 41,00 \\
\hline & Rendimento $(\mathrm{R} \$)$ & 27,39 & 30,34 & 29,25 & 28,59 \\
\hline \multicolumn{6}{|c|}{ PT - piso térmico; LI - lâmpada incandescente; RE - resistência elétrica; } \\
\hline \multicolumn{6}{|c|}{ LV - lâmpada de infravermelho; GPd - ganho de peso até o desmame. } \\
\hline
\end{tabular}

Os dados referentes ao rendimento, para fase de verão, apontam que o tratamento resistência elétrica, foi o que apresentou maior valor médio, de $R \$$ 46,22/leitão/baia avaliada, representando um valor de 19,12\% superior para o piso térmico, 37,53\% para lâmpada incandescente e 30,16\% para lâmpada de infravermelho. Por outro lado, para fase de inverno, verifica-se que, para o tratamento lâmpada incandescente o valor de rendimento mostrou-se superior, em torno de $\mathrm{R} \$$ 30,34 , cerca de $9,72 \%$ superior para o piso térmico, 3,6\% para resistência elétrica e $5,76 \%$ para lâmpada de infravermelho.

Diante desses resultados, verifica-se que os tratamentos resistência elétrica e lâmpada incandescente foram os mais viáveis economicamente, para os períodos de verão e inverno respectivamente. Mais uma vez, fica evidente que a utilização de termostato para o controle do acionamento das fontes de aquecimento é indispensável para promover uma maior economia de energia elétrica. 


\subsection{Avaliação da eficiência das ferramentas de identificação eletrônica por análise de imagem e transponders (IDRF)}

Os dados referentes aos sinais captados pelos diferentes sistemas de identificação eletrônica, utilizados como ferramentas, para análise do comportamento animal, apresentaram variação de acordo com a Figura 47. Por meio dessa comparação entre os sistemas de identificação e análise de imagem, pode-se verificar que o registro da presença dos leitões no interior dos abrigos, ficou abaixo daquela verificada pela análise de imagem, apresentando uma eficiência menor para essa aplicação. Talvez a utilização de um controlador de acesso fosse mais adequado ao estudo, visto que as antenas não captaram a identificação de todos os animais no interior do abrigo. Outra possibilidade que evidencia o menor registro dos sinais emitidos pelos transponders, são as interferências, ocasionadas pela rede de alimentação do sistema de identificação (antenas), ou seja, a presença de outros equipamentos ligados na rede, estruturas metálicas, etc.

Diversas soluções foram propostas, na tentativa de evitar essas interferências. Uma delas seria a utilização de um cilindro blindado contendo a unidade receptora (antena) e o aterramento de todo sistema de identificação (Curto, 2002).

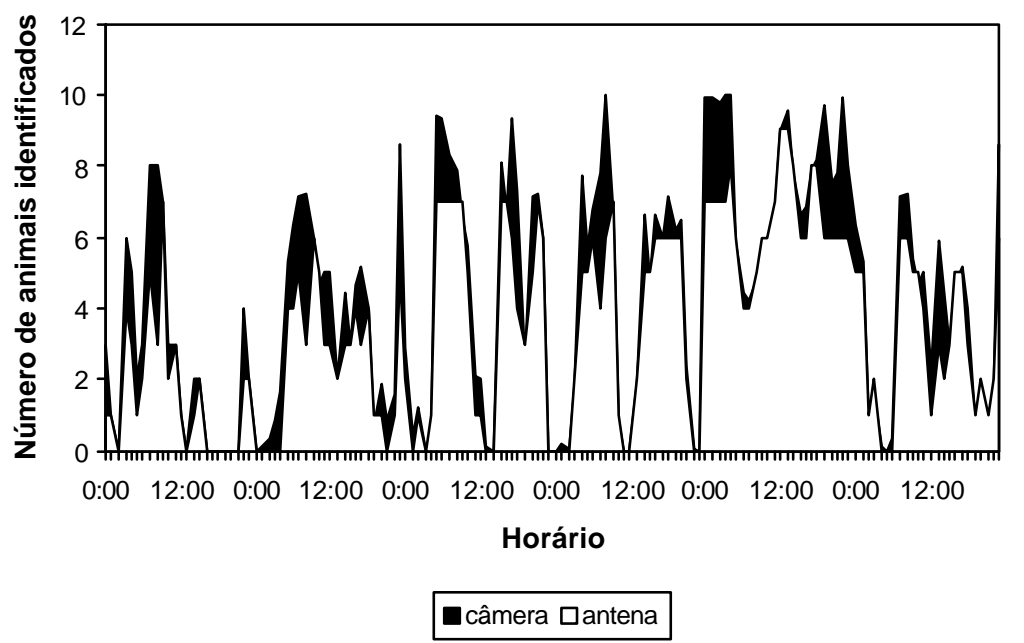

Figura 47 - Variação do número de animais captados pela câmera de vídeo e pelas antenas de recepção do sinal emitido pelos microchips. 
Em função desses aspectos, em se tratando do comportamento animal, o uso da análise de imagem permitiu também a aplicação da geoestatística no estudo da disposição dos animais ao longo do abrigo.

Para os dados referentes à validação do sistema de identificação eletrônica, número de animais captados pelas antenas em função do número de animais captados pelas câmeras de vídeo, utilizou-se análise de regressão, envolvendo dados médios horários de registro. As retas de ajuste 1:1 apresentaram uma tendência de variação linear, mostrando um valor de $\mathrm{R}^{2}(0,8677)$, significativo a $1 \%$ de probabilidade pelo teste $\mathrm{F}$, verificando-se um nível de confiança de $79 \%$, quando se comparam os dados obtidos pelas antenas em relação æ̀s microcâmeras (Figura 48).

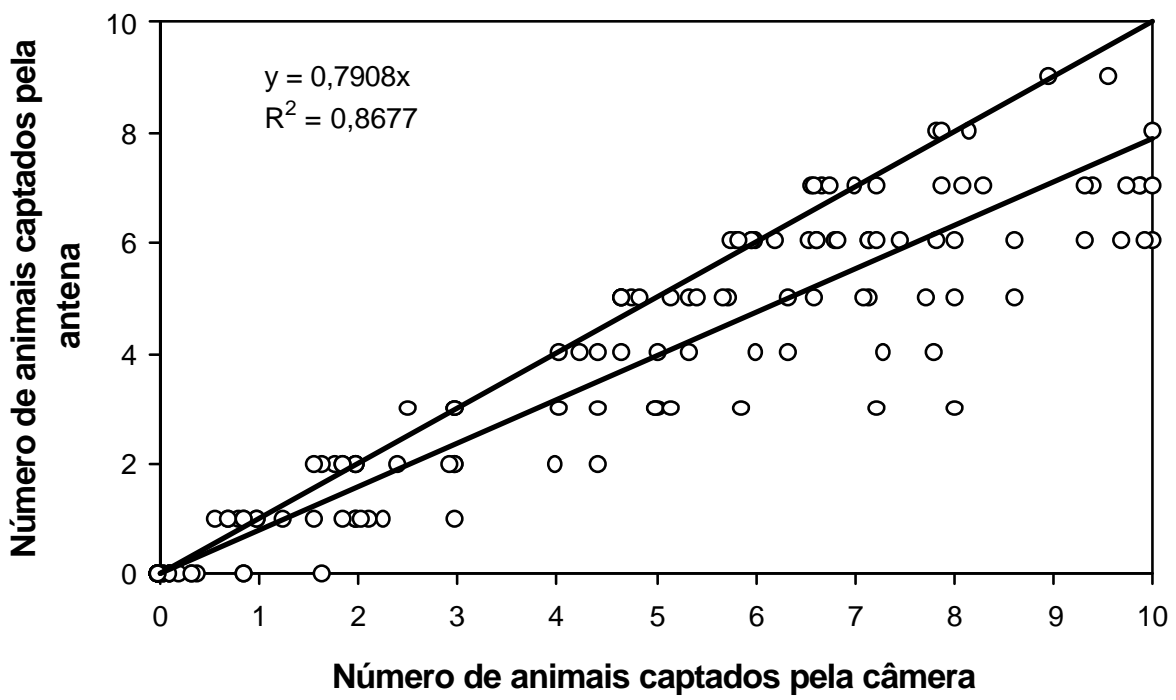

Figura 48 - Representação da correlação entre registro de dados pelas antenas e pelas microcâmeras.

Dessa forma, a confiabilidade do sistema de análise de imagem foi superior ao uso de transponders, visto que o mesmo apresentou um erro na detecção da presença dos animais no interior dos abrigos de $21 \%$. 


\section{CONCLUSÕES}

Baseando-se nos resultados dessa pesquisa, pode-se concluir que:

- as variáveis ambientais apontam que o uso de aquecimento para os leitões no período de verão para a localidade estudada é desnecessário, porém, para o período de inverno, verifica-se que a utilização de aquecimento nos abrigos escamoteadores é indispensável, em virtude das baixas temperaturas registradas nessa etapa, sendo que os sistemas de aquecimento que se mostraram mais adequados, do ponto de vista térmico, foram lâmpada incandescente e resistência elétrica;

- considerando o reflexo do aquecimento no comportamento dos leitões, o piso térmico foi o mais eficiente nas trocas de calor sensível por condução (contato), promovendo uma melhor condição de conforto aos animais, visto a alta freqüência de acesso aos abrigos e maior tempo de permanência dos animais no interior dos escamoteadores, durante os períodos estudados;

- referindo-se ao perfil de distribuição dos leitões no interior dos abrigos, verifica-se, em geral, que, para todos os tratamentos avaliados, os animais apresentaram a tendência de buscar pontos mais próximos da fonte de calor, ou as faixas de maior temperatura do piso, no horário mais frio, sendo que para o horário mais quente, o padrão de distribuição se inverteu, ou seja, os animais buscaram regiões do piso, que apresentavam faixas de menor temperatura e mais distantes da fonte de calor;

- a criação das isotermas por meio da geoestatística e análise de imagem permitiu analisar o comportamento dos animais em função das variáveis ambientais; 
- de acordo com a análise técnico-econômica realizada, verificou-se que o maior rendimento no verão foi observado no piso com resistência elétrica seguido do piso térmico, lâmpada de infravermelho e lâmpada incandescente respectivamente. No inverno, o maior rendimento foi em relação à lâmpada incandescente, resistência elétrica, lâmpada de infravermelho e piso térmico;

- quanto às ferramentas tecnológicas, o sistema que se mostrou mais eficiente foi a análise de imagem, permitindo correlacionar o perfil de distribuição dos animais e captar o maior número de informações, uma vez que o uso da identificação eletrônica apresentou um erro de detecção da presença dos animais no interior dos abrigos de $21 \%$. 


\section{REFERÊNCIAS BIBLIOGRÁFICAS}

ALBRIGHT, L.D. Environment Control for Animals and Plants. St. Joseph, Michigan: American Society of Agricultural Engineers Michigan. 1990. (ASAE Textbook, 4), p.453.

ARTMANN, R. Eletronic identification systems: state of the art and their further development. Computers and Eletronics in Agriculture, v.24, n.1, p.5-26, 1999.

BÄCKSTRÖM, L.; CURTIS, S.E. Housing and environmental influences on production. In: LEMAN, A.D. Diseases of swine. Ames: lowa State University Press, 1981. p. 737-753.

BAÊTA, F.C.; SOUZA, C.F. Ambiência em edificações rurais - conforto animal. Viçosa:UFV, 1997. 246p.

BLAIR, L.A.; FJELD, H., STROKAPPE, J.A.; REDDSON, A. Swine production and management. Saskatchewan: Canada Agriculture, 1976. 20p. (Publication, 1442).

BRENT, G. Getting piglets under cover. Pig Farming, v.27, n.6, p.63, 1979.

BRIDLE, J.E. A review of animal identification : from simple manual techiques to automatic transponding systems. Landbauforshung Völkenrode, v.18, p.127-148, 1973.

BUFFINGTON, D.E.; COLAZZO-AROCHO, A.; CATON, G.H. Black globe humidity comfort index (BGHI) as comfort equation for dairy cows. Transaction of the ASAE, v.24, n.4, p.711-714. 1981. 
COMBERG, G. Einige Bemerkungen, zum wärmedarf der Ferkel. Schweinezucht Schweinemast, v.14, n.1, p.2-3, 1966.

COX, S. W. R. Farm Electronics. Oxford: BSP Professional Books, 1988, p.235.

CURTIS, S.E. Environmental manegement in animal agriculture. Ames, lowa: State University Press, 1983. 409p.

CURTO, F.P.F. Estudo do comportamento em matrizes pesadas (frango de corte) em diferentes ambientes utilizando identificação eletrônica e radio freqüência. Campinas, 2002. 72p. Tese (Doutorado) - Faculdade de Engenharia Agrícola, Universidade Estadual de Campinas.

D`ARCE, R.D.; TEAGUE, H.S.; ROLLER, W.L. Effect of short-term elevated dry-bulb and dew-point temperature on the cycling gilt. Journal Animal Science, v.30, n.2, p.374-380, 1970.

DIVIDICH, J.L.; RINALDO, D. Effects de l'environement thérmique sur les performance du porc en croissance. Journée d la Recherche Porcine en France, n.21, p.219230, 1989.

DUSENBERY, D.B. Using a microcomputer and video camera to simultaneously track 25 animals. Computer Biological Medicine Veterinary. v.15, n.4, p.169-175, 1985.

ENGLISH, P.R.; FLOWER, V.R.; BAXTER, J.; SMITH, B. Systems for stabilishing the newly weaned pig. In: SMITH, B.; BAXTER, J. The growing and finishing pigsimproving efficiency. Ipvswich: Farming Press, 1988. p.275-329.

ERADUS, W.J.; ROSSING, W., Animal identification, key to farm automation. In.: INTERNATIONAL CONFERENCE, COMPUTERS IN AGRICULTURE, 5., Orlando, 69 Feb 1994. Proceedings. Orlando: ASAE, 1994. p. 189-193.

ESMAY, M.L. Principles of animal environment. West Port CT: ABI, 1982. 325p.

FIALHO, F.B. Modernização no controle da produção de suínos: zootecnia de precisão. 
In: SILVA, I.J.O. Ambiência e Qualidade na Produção Industrial de Suínos. Piracicaba: FEALQ, 1999. p.131-148.

GODBOUT, S.; GUIMONT, H.; MARQUIS, A.; DE FOY, C. Piglets Infrared Lamp : Halogen vs . Incandescent. In: ANNUAL INTERNATIONAL MEETING SPOUSORED, California, 2001. Proceedings. Sacramento:ASAE, 2001. p.124-127.

GOEDSEELS, V. A data-aquisition system for eletronic identification, monitoring and control of group-housed pigs. Journal Agriculture Engineer Research, v.53, n.3, p.25-33, 1992.

HEARD, R.L.; FROEHLICH, D.P.; CRISTIANSON, L.L. WOERMAN, R., WITMER, W.I. Snout cooling effects on sows and litters. Transaction of the ASAE, v.29, n.4, p.1097-1101, 1986.

HOFF, S.J. A quasi ad-libitum eletronic feeding system for gestating sows in loose housing. Computers and Eletronics in Agriculture, v.19, n.3, p.277-288, 1998.

HOLM, D.M. Passive eletronic identification with temperature monitoring. In: SYMPOSIUM ON COW IDENTIFICATION SYSTEM AND THEIR APPLICATIONS, Wageningen, 1976. Proceedings. Wageningen: IMAG, 1976. p.125-129.

KELLY, K.W. Environmental effects on the immune system of pigs. Pig News and Information, v.3, n.4, p.359-369, 1982.

KLINDTWORTH, M.; WENDEL, G.; KLINDTWORTH, K.; PIRKELMANN, H. Eletronic identification of cattle with injectable transponders. Computers and Eletronics in Agriculture, v.24, n.1, p.65-79, 1999.

KUIP, A. Animal identification. In: SYMPOSIUM AUTOMATION IN DAIRYNG, 3, Wageningen, Sep. 9-11, 1987. Proceedings. Wageningen: IMAG, 1987, p.132-136.

LAMBOOY, E.; MERKS, J.W.M. Techique and injection place of eletronic identification numbers in pigs. Zeist: , 1989.p.335 (IVO B-Rapport 335) 
LOPES, A. A.; PAZ, S. M.; CUGNASCA, C. E.; SARAIVA, A. M. Sharing Video Images on the Internet Using Java: An Application to Controlled Environment. In PROCEEDINGS OF THE WORLD CONGRESS OF COMPUTERS IN AGRICULTURE AND NATURAL RESOURCES, Foz do Iguaçu, 2002. Proceedings. Foz do Iguaçu: ASAE, 2002. p.114-118

MALIBACH, H.I.; ROVEE, D.T. Epidermal Wound Healing. (Year Book Medical). Chicago. NEDAP, 1972. p. 422

MACDONALD, R.; FELDMANN, T.; WRIGGLESWORTH, M. Comparison of Heat Lamp to Heat Pad Creep Heat in Farrowing Units In Swine Housing. In: PROCEEDINGS INTERNATIONAL CONFERENCE, 1, lowa, 2000. St. Joseph, Michigan: ASAE, 2000. p.357-364.

MORAES, N.; SOBESTIANSKY, J.; WENTZ, I.; MORENO, A.M. Manejo do leitão do nascimento até o abate. In: SOBESTIANSKY, J.; WENTZ, I.; SILVEIRA, P.R.S.; SESTI, L.A.C. Suinocultura Intensiva. Concórdia: Embrapa - CNPSA, 1998. p.135-161.

MORRISON, S.R.; GIVENS, R.L.; HEITMAN JR.H. Effects of air movement on swine at high temperature. International Journal of Biometeorology, v.20, n.4, p.337-343, 1976.

MOUNT, L.E. The Climate Physiology of the Pig., Baltimore: Williams and Welkins. 1968. $271 p$.

MOURA, D.J.; NÄÄS, I.A.; SILVA, I.J.O.; SEVEGNANI, K.B.; CORRIA, M.E. The use entalpy as a thermal comfort index. In: LIVESTICK ENVIRONMENT, V, St. Joseph, Michigan. Proceedings: St. Joseph: ASAE, 1997. v.1, p.242-248.

NÄÄS, I.A. Princípios de conforto térmico na produção animal. São Paulo: Ed. Ícone, 1989. 183p. 
NÄÄS, I.A.; RODRIGUES, E.H.V. Qualidade do ambiente para a produção de suínos na gestação e maternidade. In: SILVA, I.J.O. Ambiência e Qualidade na Produção Industrial de Suínos, Piracicaba: FEALQ, 1999. p.112-130.

NECOECHEA, A.R. Doenças e meio ambiente. Suinocultura Industrial, v.8, n.8, p.1326, 1986.

O GRADY, J.F.; LYNCH, P.B.; KEARNEY, P.A. Voluntary feed intake by lactation sows. Livestock Production Science. v.12, n.1, p.355-365, 1985.

PANDORFI, H. Suinocultura de precisão para atender à exigências do consumidor. ANUALPEC, São Paulo, 2002. p.118-121.

PANDORFI, H.; MOURA, D.J.; SILVA, I.J.O. Zootecnia de precisão: avaliação de diferentes locais de implante de microchip para identificação eletrônica de leitões. In: CONGRESSO BRASILEIRO DE ENGENHARIA AGRÍCOLA, 31., Salvador, 2002. Anais. Salvador: SBEA, 2002. p. 180-183.

PERDOMO, C.C.; NICOLAIEVISKY, S. Influência de diferentes edificações sobre o meio ambiente para suínos na época quente. Pesquisa Agropecuária Brasileira, v.23, n.4, p.439-446, 1988.

PERDOMO, C.C.; SOBESTIANSKY, J.; OLIVEIRA, P.V.A.; OLIVEIRA, J.A. Efeito de diferentes sistemas de aquecimento no desempenho de leitões. Concórdia: EMBRAPA - CNPSA, 1987. p.1-3. (Comunicado Técnico, 122 )

PEREIRA, A.R.; ANGELOCCI, L.R.; SENTELHAS, P.C. Agrometeorologia: Fundamento e Aplicações Práticas. Guaíba, RS: Agropecuária, 2002. 478p.

PEREIRA, D.F.; NÄÄS, I.A.; CURTO, F.P.F.; MURAYAMA, M. Avaliação do local do implante de microchip utilizados para identificação eletrônica em matrizes pesadas. Revista Brasileira de Ciência Avícola, v.2, n.1, p.53, 2001. (Suplemento 3). Apresentado à Conferência APINCO 2001 de Ciência e Tecnologia Avícolas, Campinas, 2001 - Resumo. 
PORKWORLD (ABCS) - www.porkworld.com.br (18 nov. 2002).

ROMA JÚNIOR, L.C.; SEVEGNANI, K.B.; SILVA, I.J.O.; MOURA, D.J.; PANDORFI, H.; CARO, I.W. Zootecnia de Precisão: migração de microchips injetáveis implantados em frangos de corte. In: CONGRESSO BRASILEIRO DE ENGENHARIA AGRÍCOLA, 31., Salvador, 2002. Anais. Salvador: SBEA, 2002. p.204-207.

ROSSI, L.A.; CARDOSO, P.E.R.; BERALDO, A.L. Desempenho de placas de argamassa de cimento e casca de arroz aquecidas por resistência elétrica. In: CONGRESSO BRASILEIRO DE ENGENHARIA AGRÍCOLA, 31., Salvador, 2002. Anais. Salvador: SBEA, 2002. p.249-252.

ROSSING, W. Animal identification: introduction and history. Computers and Electronics in Agriculture. v.24, n.1, p.1-4, 1999.

SAS INSTITUTE, Statistical Analysis System: realease 6.08, (software). Cary, 1992. $620 p$.

SCOTT, N.R.; DESHAZER, J.A.; ROLLER, W.L. Effects de thermal and gases environment on livestock. In: HELLICKSON, M. ; WALKER, J.N. Ventilation of Agricultural Structural. St. Joseph: ASAE, 1983. p.121-165.

SHAO, J.; XIN, H.; HARMON, J.D. Neural network analysis of postural behavior of young swine to determine their thermal comfort state. Transactions of the ASAE v.40, n.3, p.755-760, 1997.

SHAO, J.; XIN, H.; HARMON, J.D. Comparison of image feature extraction for classification of swine thermal comfort behavior. Computer and Electronics in Agriculture v.19, p.223-232, 1998.

SILVA, I.J.O. Qualidade do ambiente e instalações na produção industrial de suínos. In: SIMPÓSIO INTERNACIONAL DE SUINOCULTURA. São Paulo, 1999. Anais. São Paulo, SP: Gessuli, 1999. p.108-325.

SILVA, K.O.; NÄÄS, I.A.; SALGADO, D.D. Determinação do local de implante de 
microchip em suínos utilizando antena painel. In: CONGRESSO BRASILEIRO DE ENGENHARIA AGRíCOLA, 31., Salvador, 2002. Anais. Salvador: SBEA, 2002. p.108-111.

SIMMONS, J.R. Keeping piglets warm. Veterinary Record, v.98, n.19, p.381-382, 1976.

SOBESTIANSKY, J.; MORAES, N.; WENTZ, I.; MORENO, A.M. Manejo do leitão desde o nascimento até o abate. In: SOBESTIANSKY, J.R.; WENTZ, I.; SILVEIRA, P.R.S.; SESTE, L.A.C. Suinocultura intensiva: produção, manejo e saúde do rebanho. Brasília: EMBRAPA-SPI, Concórdia: EMBRAPA-CNPSA, 1998. cap.7, p.135-161.

THOMPKINS, E.C.; HEIDENREICH, C.J.; STOB, M. Effect of post-breeding thermal stress on embrionic mortality in swine. Journal Animal Science. v.26, n.2, p.377380, 1967.

VAQUERO, E.G. Projeto e construção de alojamento para animais. 7.ed. Lisboa: Litexa, 1981. 237p.

WISMANS, W.M.G. Identification and registration of animals in the European Union. Computers and Eletronics in Agriculture, v.24, n.2, p.99-108, 1999.

WOUTERS, P.; GEERS, R.; PARDUYNS, G.; GOOSSENS, K.; TRUYEN, B.; GOEDSEELS, V.; VAN DEER STUYFT, E. Image analysis parameters as inputs for automatic environmental temperature control in the piglets houses. Computers and Electronics in Agriculture v.5, n.2, p.233-246,1990.

XIN, H.; SHAO, J Real-time Assessment of Swine Thermal Comfort by Computer Vision. In: PROCEEDINGS OF THE WORLD CONGRESS OF COMPUTERS IN AGRICULTURE AND NATURAL RESOURCES. 2, Foz do Iguaçu, Brasil, 2002. Proceedings. Foz do Iguaçu:ASAE, 2002. p.362-369.

XIN, J.; BECK, H.; HALSEY, L.; FLETCHER, J.; ZAZUETA, F. Using Digital Cameras and the Internet to Identify Plant Insect and Disease Problems. In: INTERNATIONAL 
CONFERENCE ON COMPUTERS IN AGRICULTURE, 17, Orlando, 1998.

Proceedings. Orlando: ASAE, 1998. p.327-329. 